
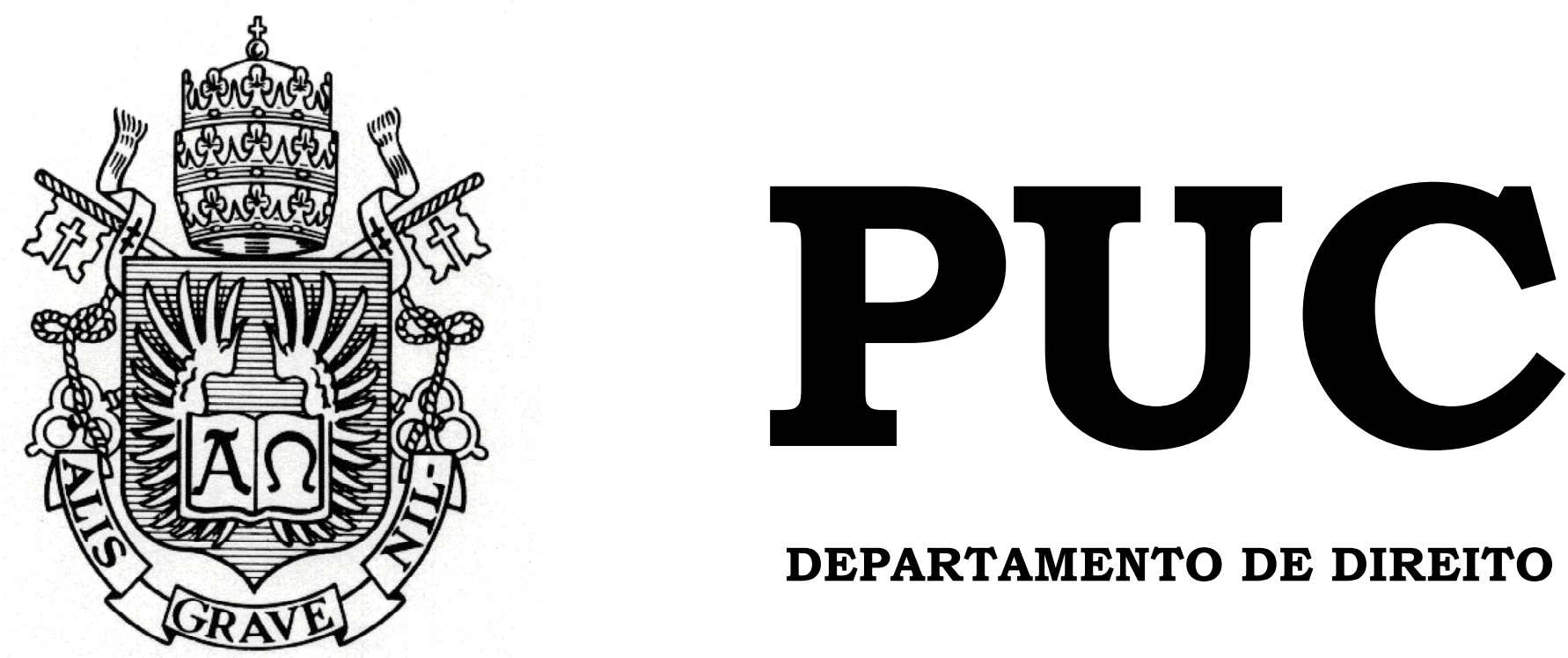

DEPARTAMENTO DE DIREITO

\title{
O DIREITO À LIBERDADE DE EXPRESSÃO CRÍTICA AO ESTADO E SEUS REPRESENTANTES EM UMA SOCIEDADE DEMOCRÁTICA
}

por

LUC ATHAYDE DE ARAUJO

ORIENTADOR(A): Fábio Carvalho Leite

2012.2

PONTIFÍCIA UNIVERSIDADE CATÓLICA DO RIO DE JANEIRO

RUA MARQUÊS DE SÃO VICENTE, 225 - CEP 22453-900

RIO DE JANEIRO - BRASIL 


\section{O DIREITO À LIBERDADE DE EXPRESSÃO CRÍTICA AO ESTADO E SEUS REPRESENTANTES EM UMA SOCIEDADE DEMOCRÁTICA}

por

\section{LUC ATHAYDE DE ARAUJO}

Monografia

apresentada

ao

Departamento de Direito da Pontificia Universidade Católica do Rio de Janeiro (PUC-Rio) como requisito parcial para a obtenção do Título de Bacharel em Direito.

Orientador(a): Fábio Carvalho Leite 
Ao meu pai, Marcelo Tristão, que transformou crítica ao Estado em seu ofício. 


\section{Agradecimentos}

A meus pais, pelo apoio incondicional à minha decisão de me rebelar contra as artes e abraçar o "tradicional" Direito.

A meus amigos e colegas dos últimos cinco anos vividos no grupo "Simulações e Realidade", que sempre me trouxeram grande alegria e admiração.

Ao professor Adriano Pilatti, por ter me puxado de volta para o mundo do estudo jurídico quando eu estava començando a achar que não havia nele um espaço para mim.

Aos professores e professoras que me inspiraram, apoiaram, e aconselharam durante os meus anos na PUC, especialmente dentre eles Márcia Nina, Carolina Melo, Letícia Paes, Danielle Moreira, e Thamis Dalsenter.

A meu orientador, Fábio Leite, por ter me intimado para discussões semanais, e por vezes calorosas, sobre este admirável e estranho direito que é a liberdade de expressão.

À professora Caitlin Mulholland, que garantiu que eu pudesse viver como quem eu realmente sou durante este último ano de faculdade, tornando também possível ver a mim mesmo na capa desta Monografia.

A Helena Rocha, que primeiro me apresentou ao direito à liberdade de expressão, me colocando em um caminho sem volta, e de infinitos debates, questionamentos, e surpresas.

A Priscilla, sem quem nada disso teria acontecido. 


\section{Resumo}

O presente trabalho explora o tema do direito à crítica de qualquer natureza realizada contra o governo e seus agentes e representantes no contexto de uma sociedade democrática, e sua supressão pelo uso de mecanismos do direito penal como as leis de desacato e de sedição. Para tal, se expõe as bases político-filosóficas que sustentam esta face do direito à liberdade de expressão desenvolvidas na Inglaterra e nos Estados Unidos, para então se realizar uma análise dos parâmetros existentes no direito internacional e comparado sobre o tema. Finalmente se busca fazer uma análise do atual marco jurídico penal brasileiro à luz de tais parâmetros, e das propostas existentes para sua reforma.

\section{Palavras-chave}

Liberdade de expressão, direito à crítica, desacato à autoridade, crimes contra a honra, leis de desacato, leis de sedição, difamação. 


\section{Sumário}

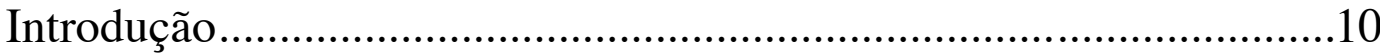

Capítulo I: Fundamentos teóricos do direito à crítica ao Estado e seus representantes em uma sociedade democrática.....................................11

1. A Inglaterra de John Milton e John Stuart Mill........................... 12

1.a Censura prévia e Areopagitica.......................................................... 12

1.b As Cartas de Catão e John Stuart Mill............................................... 21

2. Os Estados Unidos e a Lei de Difamação Sediciosa de 1798 ......29

Capítulo II: Parâmetros de direito internacional e comparado sobre o direito à crítica.......................................................................... 45

1. A Jurisprudência da Suprema Corte dos Estados Unidos......... 45

1.a As opiniões dissidentes dos Magistrados Holmes e Brandeis.............. 45

1.b O caso New York Times Co. v. Sullivan...................................50

1.c Após New York Times v. Sullivan............................................ 56

2. O Sistema Interamericano de Direitos Humanos e as "leis de desacato", .59

2.a Considerações gerais .59

2.b O Relatório de 1994 da Comissão Interamericana de Direitos Humanos.64 2.c Após o Relatório de 1994 e sua aplicação aos "crimes contra a honra”....69 2.d A Corte Interamericana e a expressão crítica a funcionários públicos: o caso Kimel v. Argentina 73

3. A Corte Constitucional da Guatemala e a descriminalização do desacato .81

Capítulo III: o Código Penal brasileiro e a proteção especial a autoridades e funcionários públicos no exercício de suas funções..87

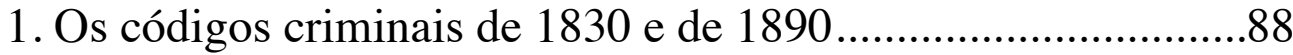

2. O Código Penal de 1940........................................................91

2.a A legislação dos "crimes contra a honra" em termos gerais...................91 
2.b disposições específicas dos crimes contra a honra relativas a funcionários e autoridades públicas no exercício de suas funções. .93

2.c $\mathrm{O}$ crime de desacato à autoridade ...................................................100

2.d $\mathrm{O}$ anteprojeto do novo código penal...........................................107

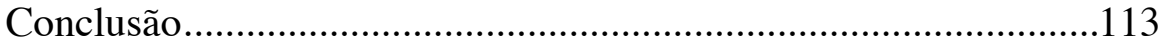

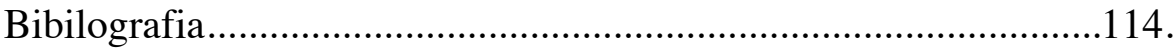


"[T]hat right of freely examining public characters and measures, and of free communication among the people thereon, (...) has ever been justly deemed the only effectual guardian of every other right." (James Madison, Resoluções do Estado de Virginia de 1798) 


\section{Introdução}

A relação fundamental entre o direito à liberdade de expressão e a democracia - a ideia de que a liberdade de expressão é uma condição sine qua non para a existência e legitimidade de uma democracia - é uma noção amplamente propagada e aceita na teoria e jurisprudência contemporâneas que interpretam a extensão e aplicação deste direito. Tal constatação desta relação é frequentemente utilizada, seja pela doutrina ou pelos Tribunais, para fundamentar a necessidade de uma proteção ampla ao direito à liberdade de expressão quanto este é exercido para a emissão de opiniões e críticas de qualquer natureza relacionadas a assuntos públicos, ou direcionadas a pessoas públicas, em especial dentre estes, funcionários públicos no exercício de suas funções.

Não obstante, até os dias de hoje, instrumentos jurídicos relíquias de governos autoritários - como as leis de desacato e as leis de difamação sedicosa - seguem sendo utilizados em diversos Estados democráticos como um meio de outogar uma proteção especial à honra e à reputação de autoridades, funcionários, e servidores públicos, suprimindo direta e indiretamente pelo uso do direito penal, a crítica ao governo e seus representantes pela população. Nesta linha, o Código Penal brasileiro, redigido em 1940, segue prevendo dispositivos que cristalizam uma lógica de maior proteção à Administração Pública e à necessidade de manutenção de seu prestígio e autoridade contra as críticas e opiniões de seus jurisdicionados, restringindo assim o controle social democrático do povo soberano sobre aqueles que os representam.

Diante deste quadro, esta monografia tem como objetivo a realização de uma análise crítica da normativa criminal no que diz respeito às disposições equivalentes ao "desacato" previstas no atual Código. Para a realização de tal problematização, se procurou examinar e expor as bases políticas, filosóficas, e jurídicas que sustentam a relação intrínseca entre 
o direito à liberdade de expressão e a democracia, mais especificamente na medida em que possibilita crítica e a discussão sobre assuntos, pessoas, e questões públicas.

Deste modo, no Capítulo I, será realizado o estudo das bases filóficas e políticas a respeito do direito à liberdade de expressão desenvolvidas na Inglaterra e nos Estados Unidos nos últimos séculos. Na Inglaterra, se analisará a clássica obra em defesa da expressão Areopagitica, de John Milton, e o contexto no qual sua filosofia foi desenvolvida, assim como o artigo A Liberdade, de John Stuart Mill. Ambos os autores foram selecionados pela relevância que possuem para o desenvolvimento jurídico do direito à liberdade de expressão, sendo constantemente a referência de Tribunais internacionais e nacionais em casos paradigmáticos envolvendo este direito. Já nos Estados Unidos, será realizado um estudo da controversa "Lei de Difamação Sediciosa" de 1798, a qual previa a criminalização especial do discurso ofensivo a altas autoridades do Estado, de maneira paralela a como ainda o fazem as leis de desacato na América Latina. É no contexto político da aprovação e a aplicação da lei que serão fixadas as principais fundamentações em defesa do direito à crítica a autoridades públicas, as quais também se encontrarão refletidas na jurisprudência do século XX.

No Capítulo II, serão expostos os parâmetros existentes na jurisprudência internacional e comparada a respeito da necessidade de proteção do discurso crítico relacionado a assuntos e pessoas públicas - e da conseqüente necessidade de revogação de leis que, de maneira contrária, buscam a proteção especial de autoridades e funcionários públicos no exercício de suas funções. Assim, em um primeiro momento, será analisada a jurisprudência da Suprema Corte americana sobre a questão, e, em especial, o paradigmático caso New York Times $v$. Sullivan. O caso foi selecionado não apenas por sua importância reconhecida para a proteção do direito à liberdade de expressão ao redor do mundo, mas também por configurar uma resposta jurídica contemporânea aos debates travados no 
marco das discussões políticas a respeito da Lei de Difamação Sediciosa de 1798, analisada no capítulo I. Para além dos Estados Unidos, se exporá o marco jurídico desenvolvido pelos os órgãos do Sistema Interamericano de Direitos Humanos no que se relaciona às leis de desacato e aos "crimes contra a honra" quando utilizados para a sanção da opinião crítica do Estado e seus representantes. Os parâmetros desenvolvidos pelo Sistema Interamericano nas últimos duas décadas vem sendo incorporados por outros países da região, os quais vêm reconhecendo a proteção especial que deve ser conferida a tais expressões críticas. A título de exemplo, analisaremos a decisão da Corte Constituicional da Guatemala que determinou a inconstitucionalidade do delito de desacato, com a incorporação dos parâmetros desenvolvidos tanto pela Suprema Corte americana como pelos órgãos do Sistema Interamericano.

No Capítulo III será realizado um estudo crítico das normas atualmente existentes no Código Penal brasileiro que protegem de maneira especial a honra e a reputação de funcionários públicos à luz dos parâmetros expostos. Para tal, será também exposta a doutrina de autores clássicos e contemporâneos desenvolvidas nos manuais de Direito Penal, e as justificativas utilizadas para a manutenção de tais normas. Finalmente, será realizado uma análise do anteprojeto do novo Código Penal redigido em junho de 2012 por uma Comissão de Juristas, buscando determinar se as propostas apresentadas resultariam em uma maior proteção da expressão crítica ao Estado e seus agentes, ou se implicariam em um retrocesso do marco jurídico atual. 


\section{Capítulo I: Fundamentos teóricos do direito à crítica ao Estado e seus representantes em uma sociedade democrática}

As bases filosóficas e políticas modernas que sustentam a relação entre a liberdade de expressão, a democracia, e o consequente direito à crítica e à divergência, começam a ser desenvolvidas já no século XVII, por John Milton, e se ampliam após a revolução americana e a adoção da constituição dos Estados Unidos e sua carta de direitos (Bill of Rights), como observado por Tocqueville. Em meados do século XIX, o britânico John Stuart Mill escreverá sua famosa obra A Liberdade, que expandirá o fundamento para a defesa de pensamentos divergentes e críticos, e a importância da tolerância deste tipo de discurso.

Neste sentido, a Inglaterra - em um contexto de luta por uma maior representação parlamentar - e os Estados Unidos - na criação de um governo democrático republicano e na fomentação de uma tradição de divergir - se tornarão palcos de discussão da era moderna sobre o que constitui o direito à liberdade de expressão, quais são seus fundamentos, e qual a sua importância para a democracia.

Seja por meio da imposição de mecanismos de licença prévia na Inglaterra no século XVII, ou pela edição das leis de difamação sediciosa (Sedition Laws) nos Estados Unidos no final do século XVIII, ambos estes países trouxeram à tona reflexões importantes a respeito do direito à liberdade de expressão e de seus limites a partir de tentativas de supressão do discurso, particularmente daquele discurso que era visto como uma ameaça ao Estado, e a seus governantes. Deste modo, é fundamental também entender o contexto existente quando os autores supracitados desenvolveram suas teses e ideias sobre o direito à liberdade de expressão. Esta contextualização será especialmente relevante para entender o 
momento histórico em que Tocqueville irá observar a democracia estadunidense, e para a análise dos argumentos e discussões travadas nos Estados Unidos após a promulgação de uma lei proibindo a crítica ao governo (Alien and Sedition Acts of 1798).

Neste sentido, neste capítulo propomos explicitar e demonstrar as bases filosóficas e políticas que sustentam a especial proteção do direito à liberdade de expressão em sua relação com a democrácia, e particularmente no que tange ao direito de crítica a autoridades e figuras públicas. Para tal, em um primeiro momento será feita uma análise das filosofias de John Milton e John Stuart Mill, na Inglaterra, assim como do contexto em que suas principais obras relativas ao direito à liberdade de expressão foram escritas. Em um segundo momento, serão analisados os argumentos políticos e filosóficos desenvolvidos por diversos autores e congressistas nos Estados Unidos a respeito da aprovação da Lei de Difamação Sediciosa de 1798, que criminalizou o discurso crítico contra o governo. Como será posteriormente demonstrado no capítulo II, as ideias desenvolvidas nestes dois países nos períodos apontados formarão as bases para os fundamentos jurídicos desenvolvidos ao longo do século XX e do início do século XXI por tribunais superiores e órgãos internacionais para a proteção especial da liberdade de expressão quando se trata da linguagem crítica a figuras públicas em um contexto democrático.

\section{A Inglaterra de John Milton e John Stuart Mill}

\section{1.a Censura prévia e Areopagitica}

Desde a constituição da Magna Carta, em 1215, que passou a restringir os poderes do monarca, garantindo direitos aos cidadãos, os ingleses desenvolveram a tradição de se verem como homens livres, cujo direito à liberdade era dado ao nascer ${ }^{1}$. Ao mesmo tempo, a história da Inglaterra é marcada pela supressão à liberdade de expressão pelo governo,

\footnotetext{
${ }^{1}$ FELDMAN, Stephen. Free expression and Democracy in America: A History. Edição do Kindle (Amazon). Chicago e Londres: Unuversity of Chicago Press, 2008, localização 106.
} 
com base na busca pela paz e ordem social, e na proteção de valores culturais e religiosos e da dignidade de oficiais estatais. Neste sentido, o governo inglês possuía duas principais formas para controlar a liberdade de expressão de seus cidadãos: a censura prévia - estabelecida por um sistema de licenças prévias para publicação existente desde 1538 - e a punição do chamado crime de difamação sediciosa, um tipo penal da common law utilizado para punir expressões que pudessem atentar contra a ordem social, o governo, e a dignidade e reputação de autoridades públicas ${ }^{2}$.

O autor contemporâneo Anthony Lewis descreve as leis de difamação sediciosa como um instrumento de repressão da liberdade de expressão que poderia ser ainda mais intimidador do que a própria censura prévia $^{3}$. Segundo Lewis, ao proteger o Estado, a Igreja, e suas autoridades, as leis de sedição tinham como premissa:

"que estas instituições tinham que ter respeito pelo país para evitar o terrível perigo do caos social. Se você publicasse algo crítico-uma acusação, por exemplo, de que uma autoridade aceitou um suborno - não era suficiente a prova de que a afirmação era verdade. A verdade não era uma defesa para o crime de difamação sediciosa. O crime constituía na redução do respeito do público pela autoridade, de modo que uma crítica verdadeira poderia ser até pior do que uma falsa." 4

O principal órgão que julgava os crimes de difamação sediciosa era o chamado Star Chamber, um órgão judicial repressivo, sem garantias de devido processo legal, e administrado pelo Monarca. Tal Corte era utilizada especialmente para o julgamento de dissidentes, com base em crimes como traição, conspiração, e, como mencionado, difamação sediciosa ${ }^{5}$.

Durante o século XVII, a Inglaterra passou por uma guerra civil, um período de interregnum, e a Revolução Gloriosa no final do século. Foram momentos de instabilidade social e descontentamento com o governo que culminaram com a execução do Rei Carlos I em uma tentativa de estabelecimento de um governo republicano baseado na soberania do povo,

\footnotetext{
${ }^{2}$ Ibid. localização 111 e 116.

${ }^{3}$ LEWIS, Anthony. Freedom for the Thought That We Hate: A Biography of the First Amendment. Edição do Kindle (Amazon). Nova Iorque: Basic Books, 2007, p. 1

${ }^{4}$ Ibid. p. 2 (tradução livre).

${ }^{5}$ CURTIS, Michael Kent. Free Speech, "The People's Darling Privilege": Struggles for Freedom of Expression in American History. Edição do Kindle (Amazon). Durham e Londres: Duke Univeristy Press, 2000, localização 383; FELDMAN, Stephen. Op. cit., localização 119.
} 
e não do monarca. Especialmente no período da Guerra Civil, o antagonismo da população com o poder monárquico levou maiores críticas dirigidas a autoridades públicas e o início de uma tradição social de expressão de divergência ${ }^{6}$.

Especialmente durante a Guerra Civil dos anos de 1640, que levou ao conflito do Parlamento com a Monarquia, este descontentamento pode ser observado na formação de grupos como os chamados levellers, opositores e críticos do Estado, os quais pregavam uma ideologia de igualdade e de soberania do povo, lutando pelo direito de maior representação no Parlamento (como, por exemplo, por meio da abolição da Câmara dos Lordes, cujos membros têm seu cargo por hereditariedade), e de ampla liberdade de expressão. Neste sentido, os levellers adotaram a ideia de estabelecer uma constituição que expressasse a vontade de um povo soberano, limitando o poder do Estado ${ }^{7}$.

Após a Guerra Civil, no período de interregnum, o Parlamento aboliu a Corte do Star Chamber, até então utilizada amplamente pela monarquia para suprimir expressões divergentes por meio do crime de difamação sediciosa. Esta abolição foi impulsionada, entre outros motivos, pelo nível da repressão utilizado pela monarquia em processos contra líderes populares que atuaram na Guerra $\mathrm{Civil}^{8}$. Apesar da abolição da Corte, a cultura inglesa de punição da expressão por meio da difamação sediciosa seguiu vigente nos tribunais que aplicavam a common law. A título de exemplo, os Parlamentaristas processaram diversos líderes dos levellers por crimes de sedição e traição, pelo discurso dos levellers a favor da igualdade e maior representação no Parlamento, assim como pela propagação da ideia de que os poderes do Parlamento deveriam ser limitados (e não apenas os poderes do Monarca) ${ }^{9}$.

\footnotetext{
${ }^{6}$ FELDMAN, Stephen. Op. cit., localização 109-119.

${ }^{7}$ CURTIS, Michael Kent. Op. cit. localização 343-353.

${ }^{8}$ FELDMAN, Stephen. Op. cit., localização 119; CURTIS, Michael Kent. Op. cit. localização 389.

${ }^{9}$ CURTIS, Michael Kent. Op. cit. localização 439.
} 
Além das leis de difamação sediciosa, a Inglaterra do século XVII se utilizava amplamente de mecanismos de censura prévia para o controle da imprensa, requerendo uma licença outorgada por um órgão governamental composto por agentes estatais que determinavam se as publicações eram "aceitáveis" segundo o governo antes de publicá-las. Deste modo, a licença prévia era um instrumento importante de supressão do discurso crítico ao Estado $^{10}$. O sistema de licença prévia já existia durante o regime monárquico, mas havia sido abolido junto com o Star Chamber em $1641^{11}$. No entanto, após ganhar o controle político durante a Guerra Civil, os parlamentaristas, agora no poder, reintroduziram muitas das disposições que regulamentavam o licenciamento prévio de obras por meio da Ordenamento de Licenças (Licensing Order) de $1643^{12}$.

É neste contexto que, no ano de 1644, John Milton escreve seu clássico discurso Areopagitica, se levantando contra o processo de licença prévia estabelecido pelo Parlamento britânico ${ }^{13}$. O livro foi publicado por sua própria conta, sem o selo de aprovação governamental, e constitui uma crítica ao Estado protestante parlamentarista britânico o qual buscava, por meio de um sistema de licenciamento de publicações, suprimir "os mais recentes abusos e desordens frequentes na publicação de muitos artigos, panfletos e livros falsos, forjados, escandalosos, sediciosos, difamatórios e sem licença, para a grande difamação da religião e do governo" ${ }^{14}$.

Milton havia apoiado a causa parlamentarista durante a Guerra Civil, mas se transformou em um crítico do restabelecimento do sistema de licenciamento prévio, especialmente após ter tido publicações suas

\footnotetext{
${ }^{10}$ CURTIS, Michael Kent. Op. cit. localização 390-400.

${ }^{11}$ FELDMAN, Stephen. Op. cit., localização 125; LEWIS, Anthony. Op. Cit., p. 2. ver também: Court of Star Chamber. In: ___ Encyclopedia Britânica On-line. Disponível em: $<$ http://www.britannica.com/EBchecked/topic/563475/Court-of-Star-Chamber $>$. Acesso em 8 de novembro de 2012.

${ }^{12}$ June 1643: An Ordinance for the Regulating of Printing. Atos e ordenâncias do Interregnum, 1642-1660 (1911), pp. 184-186. Disponível em: <http://www.britishhistory .ac.uk/report.aspx? compid=55829> . Acesso em 8 de novembro de 2012.

${ }^{13}$ FELDMAN, Stephen. Op. cit., localização 120;

${ }^{14}$ June 1643: An Ordinance for the Regulating of Printing. Op. cit.
} 
censuradas que expressavam uma posição favorável ao divórcio ${ }^{15}$. Neste sentido, o livro Areopagitica se trata de uma crítica a uma política do governo parlamentarista que buscava censurar visões que não estavam de acordo com o entendimento hegemônico daqueles no poder.

É importante entender o contexto no qual Milton escreve, assim como o foco de sua crítica. Assim, ao mesmo tempo em que o autor se insurge contra o sistema de licenciamento e censura prévia, em momento algum Milton propõe que o sistema de responsabilidade ulterior por chamados "abusos" ao direito à liberdade de expressão deveria ser abolido, ou que as sedition laws violariam a liberdade de expressão. Pelo contrário, Milton chega a afirmar que discursos que difamatórios deveriam ser punidos das maneiras mais severas, contanto que tal discurso não fosse previamente censurado:

"Eu não nego que é da maior importância para a Igreja e o Estado o olhar vigilante, pois livros podem causar tanto dano quanto homens; e portanto deve-se a eles confinar, aprisionar, e levar justiça da mais firme, como malfeitores. ${ }^{16 "}$

Não obstante, em sua obra, Milton irá introduzir alguns temas relativos à proteção do direito à liberdade de expressão que irão influenciar pensadores, juristas, acadêmicos e dissidentes políticos não apenas de seu tempo, mas também em décadas e séculos posteriores com relação ao direito à crítica e à importância de tolerância a ideias distintas.

Já no início de seu discurso, ao justificar a publicação da crítica ao Parlamento, John Milton definirá que a própria crítica, quando ouvida e considerada, leva ao alcance da liberdade civil. A própria crítica política, Milton argumenta, feita por aquele que livremente declara o que poderia ser melhor, é uma prova da fidelidade de um cidadão ao Parlamento, e não de sua traição ${ }^{17}$. Esta posição já demonstra uma mudança com relação ao antigo sistema monárquico, uma vez que o cidadão crítico a uma posição

15 Areopagitica. In:______Encyclopedia Britânica On-line. Disponível em:

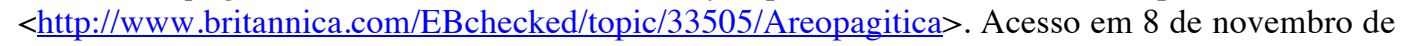
2012.

${ }^{16}$ MILTON, John. Areopagitica: A speech for the Liberty of Unlicensed Printing to the Parliament of England. Edição de Kindle (Amazon). Domínio público. 1644, localização 59. (Tradução livre.)

${ }^{17}$ Ibid. localização 15-23. 
adotada pelo governo deve ser visto não como um traidor - como o era aquele que criticava o Rei - mas sim como alguém que contribui para o bem comum.

Milton irá conectar a origem do sistema de licenciamento prévio de publicações com o autoritarismo da Igreja Católica (como assim entendiam os protestantes ingleses), buscando portanto afirmar que o licenciamento prévio não está de acordo com a liberdade que é garantida aos ingleses, mas, pelo contrário, nasce do "Conselho mais anti-cristão e da Inquisição mais tirânica que jamais inquiriu" ${ }^{18}$. Neste viés, a tentativa de controle do conhecimento é uma característica de um governo autoritário, enquanto aqueles Estados cujos cidadãos são livres devem permitir a publicação de todos os materiais, sejam estes hereges ou críticos.

Em sua crítica política ao Parlamento, Milton acusa o Estado de não confiar em seus cidadãos, por acreditá-los suscetíveis a todo tipo de argumento, e sem a capacidade de discernimento. O Parlamento atual, alega o autor, busca a supressão da liberdade de expressão de maneira contraditória, após lutar pela ampla liberdade de expressão para combater o catolicismo na Inglaterra. Nesta passagem, o autor critica e faz alusão a uma realidade comum até os dias de hoje: a tolerância ao discurso dissidente quando este é relevante politicamente para um determinado grupo hegemônico, e a supressão da crítica quando esta não mais é politicamente vantajosa:

"Quem não pode senão discernir a qualidade desta mudança política, e quem são seus planejadores; que enquanto os bispos deveriam ser suprimidos, todas as prensas deveriam estar abertas; era o direito ao nascer e o privilégio do povo no tempo do Parlamento, era a entrada da luz. Mas agora, os bispos renunciaram e esvaziaram a Igreja, como se nossa Reforma não buscasse nada além de abrir espaço para outros ocuparem suas cadeiras sob um outro nome, as artes episcopais começam a nascer novamente, o jarro da verdade não mais pode correr, a liberdade na publicação deve ser suprimira novamente por uma comissão de vinte, os privilégios do povo anulados, e, o que é pior, a liberdade de conhecer deve gemer de novo, de volta a suas algemas: tudo isso com o Parlamento ainda em sessão. ${ }^{19}$,

\footnotetext{
${ }^{18}$ Ibid. localização 147.

${ }^{19}$ Ibid. localização 450 (tradução livre).
} 
Milton atribui a causa da liberdade de escrever e falar a um governo livre e humano, e, neste sentido, atribuí ao Parlamento a aquisição desta liberdade para os ingleses. Consequentemente, o Parlamento não pode agora pretender tornar o povo menos capaz restringindo sua liberdade expressão sem tornar o próprio Parlamento um órgão que não busca a liberdade $^{20}$.

Outro tema explorado por Milton em seu discurso é a maior tolerância de todas as ideias, mesmo sendo estas divergentes do pensamento hegemônico, ou capazes de levar ao "mal", uma vez que é preciso conhecer argumentos contrários para rebatê-los. Assim, Milton caracteriza a licença prévia como uma forma autoritária de supressão do conhecimento. Segundo o autor "todas as opiniões, mesmo erros, conhecidos, lidos e coletados, são de serviço e assistência primaz na obtenção célere do que é mais verdade ${ }^{\text {,21 }}$, uma vez que a verdade, quando confrontada com a falsidade em um ambiente livre e aberto, seria eventualmente derrotada. Deste modo, toda ideia seria válida, e mesmo aquelas tidas como "perigosas" (como críticas ao pensamento hegemônico) deveriam ter espaço para serem discutidas e, se fosse o caso, descartadas ${ }^{22}$.

Enquanto a queima de livros por pessoas privadas é defendida por Milton como uma forma de expressão, a proibição legal de livros pelo Estado é uma medida autoritária, e não é adequada para a restrição de ideias consideradas perigosas. Segundo o autor, as ideias irão se propagar, mesmo que não na forma escrita, e seria necessário ao Estado proibir todo o tipo de expressão para alcançar seu fim. Pelo contrário: ideias proibidas ganham uma autoridade instantânea apenas pelo fato de serem proibidas, e pensamentos não podem ser controlados. Milton conclui que apenas com a discussão aberta de ideias "perigosas" seria possível sua real refutação ${ }^{23}$.

\footnotetext{
${ }^{20}$ Ibid. localização 457.

${ }^{21}$ Ibid. localização 194, 596 (tradução livre).

${ }^{22}$ Ibid. localização 618.

${ }^{23}$ Ibid. localização 205, 489, 237.
} 
Segundo Milton, o sistema de licença prévia leva ainda à supressão não apenas do conhecimento já existe, mas da criação e desenvolvimento de novas ideias e saberes, uma vez que há um desincentivo aos autores de buscar o conhecimento e publicar, sob o risco de que uma banca de licenciadores censurem o material. Milton conclui que o silêncio pode parecer uma melhor alternativa do que ter que sofrer a repressão da licença prévia após a conclusão de um longo trabalho:

"Ou então seria melhor restar silente, quando tudo que ensina, tudo o que expressa, é somente sob a tutela, sob a correção de seu licenciador patriarcal manchando ou alterando aquilo com que não concorde precisamente, mediante o inflexível capricho que ele denomina julgamento" 24 .

$\mathrm{O}$ autor conclui que o sistema de licença prévia gera uma estagnação do conhecimento, que passa a refletir apenas o que já existe e é aceito pela sociedade, sem a constituição de novas e variadas ideias. Milton alega que a tolerância de formas de expressão diversificadas é necessária na sociedade, criando uma simetria e harmonia social. Se todos não podem dividir as mesmas ideias, a solução para Milton é aceitação da diversidade, e não sua supressão $0^{25}$.

$\mathrm{Na}$ parte final de seu discurso, Milton reafirma o valor superior do direito à liberdade de expressão, o colocando acima de outras liberdades: "Dê-me a liberdade de saber, de falar, e de discutir livremente de acordo com minha consciência, acima de todas as liberdades" ${ }^{26}$.

As ideias desenvolvidas em Areopagitica serão reafirmadas e desenvolvidas por diversos filósofos, autores, juristas e pensadores ao longo dos séculos, notadamente a importância da maior tolerância por ideias divergentes plurais em uma sociedade democrática. Milton também parece ter iniciado a introduzir a doutrina do "mercado de ideias" (marketplace of ideas), e que, séculos após, será adotada pelo Juiz da Suprema Corte americana Holmes, em seu voto dissidente no caso Abrams v. United

\footnotetext{
${ }^{24}$ Ibid. localização 377 (tradução livre).

${ }^{25}$ Ibid. localização 567-575.

${ }^{26}$ Ibid. localização 604 (tradução livre).
} 
States $^{27}$, e passará a orientar a jurisprudência da Suprema Corte ${ }^{28}$. Como já demonstrado, ao advogar pela aceitação da propagação de ideias distintas na sociedade, Milton alega ser esta a melhor forma de se chegar à verdade, considerando ainda que, em um debate aberto e livre, a verdade sempre prevalecerá. Esta visão será ainda desenvolvida por John Stuart Mill, como se verá adiante, e tem ampla implicação na doutrina relativa ao direito à liberdade de expressão até hoje, mesmo sendo criticada por diversos autores ${ }^{29}$.

Especialmente com relação ao direito à crítica, Areopagitica não apenas configurou em si uma crítica às ações do Parlamento, mas estabeleceu as bases para a ligação intrínseca entre a liberdade de expressão e um governo democrático, conectando a prática da censura prévia (e a restrição da liberdade de expressão) com um governo autoritário, seja este a Monarquia, ou a Igreja Católica.

Em seus efeitos mais imediatos, a publicação não autorizada de Areopagitica inspirou e deu força aos levellers, também antigos apoiadores da causa parlamentarista, e, como Milton, dissidentes durante $\mathrm{o}$ interregnum $^{30}$. Panfletos escritos por líderes deste movimento defendem a liberdade de expressão, e argumentam que apenas o próprio discurso é adequado para combater eventuais abusos cometidos, e não a punição posterior ou censura prévia. Pela persecução criminal com base no crime de sedição e traição sofrida por diversos membros do grupo, assim como por sua visão de soberania popular, os levellers focaram suas críticas na criminalização da expressão pelo delito de sedição, além do ataque ao sistema de licenciamento prévio com base na supressão da informação disponível ao povo gerada por este ${ }^{31}$.

\footnotetext{
${ }^{27}$ Supreme Court of the United States. Abrams et al v. United States/ 250 U.S. 616, Rel. Justice Clarke, District of Columbia, 10 de novembro de 1919.

${ }^{28}$ Supreme Court of the United States. New York Times Co. v. Sullivan /376 U.S. 254, Rel. Justice Brennan, District of Columbia, 9 de março de 1964.

${ }^{29}$ FELDMAN, Stephen. Op. cit., localização 6554.

${ }^{30}$ CURTIS, Michael Kent. Op. cit. localização 431.

${ }^{31}$ Ibid. 426
} 
Neste sentido, os levellers defendiam uma liberdade de expressão mais ampla do que aquela proposta por Milton. Como já ressaltado, Milton não via qualquer problema com responsabilidade ulterior e com a aplicação do direito criminal para combater expressões difamatórias ou maliciosas, contanto que a publicação destas não fosse previamente proibida. Sob esta ótica, um cidadão poderia criticar duramente o governo em uma publicação (como, inclusive, Milton o fez por meio da Areopagitica), e, se tal crítica fosse entendida como se enquadrando na definição do crime de sedição ou traição, poderia ser duramente sancionada, seja com a prisão, penas corporais, ou até mesmo execução ${ }^{32}$.

\section{1.b As Cartas de Catão e John Stuart Mill}

Já no século XVIII, após a Revolução Gloriosa e o retorno à Monarquia, desta vez com maiores limitações ao poder do monarca, enquanto o Parlamento ganhava maiores prerrogativas e menos limites, os chamados radical whigs, um movimento radical inglês que apoiava ideias similares aos antigos - e já extintos - levellers começa a surgir ${ }^{33}$. Este movimento, influenciado pela filosofia de John Locke de que o governo deve ter como base o consentimento de um povo livre, também lutava por um Parlamento sem a câmara hereditária dos Lordes, e pela abolição da monarquia. Com o prosseguimento das restrições impostas pelo Parlamento à liberdade de expressão, mesmo após a abolição do sistema de licenciamento prévio, através do uso do crime de difamação sediciosa, os radical whigs também ligavam o direito à liberdade de expressão à teoria da soberania popular, sendo a expressão a forma de realização da soberania do povo sobre o governo. O pensamento dos whigs terá grande influência na sociedade americana colonial pré-revolucionária, e muitas de seus escritos

\footnotetext{
${ }^{32}$ MILTON, John. Op. cit. localização, 57-59.

${ }^{33}$ CURTIS, Michael Kent. Op. cit. localização 468.
} 
serão republicados nos Estados Unidos antes e depois da Declaração de Independência ${ }^{34}$.

Dentre estes, é relevante citar dois dos mais influentes autores dos radical whigs na sociedade americana e inglesa no que tange o direito à crítica e à liberdade de expressão: John Trenchard e William Gordon, autores das famosas Cato's Letters, or Essays on Liberty, Civil and Religious, cartas escritas sob o pseudônimo de Catão, e publicadas nos jornais ingleses em $1723^{35}$. Michael Kent, citando o historiador Leonard Levy, argumenta que as "Cartas de Catão" haviam sido também publicadas em todos os jornais da América Colonial, e eram a fonte mais popular e estimada de ideias políticas nas treze colônias $^{36}$. Seus ideais sobre liberdade de expressão chegaram a repercutir em declarações de direitos de diversos estados Americanos ${ }^{37}$.

Segundo as "Cartas de Catão", o direito à liberdade de expressão é um privilégio sagrado, e o direito "protetor da liberdade", e é essencial para um governo livre ${ }^{38}$. A necessidade da garantia da liberdade de expressão sobre assuntos públicos é vista por Catão na lógica da soberania popular: é preciso que o povo tenha a liberdade de criticar o governo e o monitorar, assim como avaliar a condução da coisa pública. Apenas um governo opressor, portanto, buscaria a supressão deste direito. Assim como Milton, as Cartas criticam um governo que apoie a liberdade de expressão, mas, ao chegar ao poder, busca suprimi-la, como fez o Parlamento:

"This Liberty has been approved or condemned by all Men, and all Parties, in proportion as they were advantaged, or annoy'd by it: When they were in Power, they were unwilling to have their Actions scanned and censured, and cried out, that such Licence ought not to be tolerated in any well constituted commonwealth; and when they suffered under the Weight of Power, they thought it very hard not to have been allowed the Liberty to utter their Groans, and to alleviate their Pain, by venting some Part of it in Complaints. ${ }^{39,}$

\footnotetext{
${ }^{34}$ CURTIS, Michael Kent. Op. cit. localização 472, 491, 496.

${ }^{35}$ Ibid. localização 496, 501.

${ }^{36}$ Ibid. 501.

${ }^{37}$ FELDMAN, Stephen. Op. cit., localização 746-765

38 TRENCHAND \& GORDON. Cato's Letters, or Essays on Liberty, Civil and Religious, and Other Importante Subjects. 1724. Apud: FELDMAN, Stephen. Op. cit., localização 146.

39 TRENCHAND \& GORDON. Cato's Letters, or Essays on Liberty, Civil and Religious, and Other Importante Subjects. 1724. Apud: CURTIS, Michael Kent. Op. cit., localização, 533
} 
Neste viés, as Cartas argumentam que um governo que não sofre críticas é um governo tirânico; as autoridades públicas só merecem ser elogiadas se se portam bem, "but to do publick mischief, without hearing of it, is only the prerrogative and felicity of tyranny: a free people Will be shweing that they are so, by their freedom of speech" 40 .

Não obstante, a posição de Catão é ambígua quando ao crime de difamação sediciosa, aceitando a punição daqueles que abusassem do direito à liberdade de expressão e difamassem o Estado imputando-lhe condutas falsas ou maliciosas. No entanto, as Cartas pregavam maiores garantias, como a presunção de inocência e a exceção da verdade, no julgamento de tais crimes ${ }^{41}$.

Mesmo apresentando uma posição aparentemente a favor da punição penal de abusos da expressão, Catão faz uma ponderação entre a supressão da liberdade de pensamento e a punição pela difamação, concluindo que uma lei que fosse capaz de punir toda difamação acabaria tendo que ser tão abrangente que tornaria toda expressão passível de punição, e, consequentemente, perigosa para quem a proclama. Neste sentido, as Cartas remetem ao conceito contemporâneo do "chilling effect", isto é, a autocensura gerada por um sistema que pune expressões a partir de uma definição tão abrangente que a falta de definição sobre que expressões são proibidas levam à insagurança e à consequente autorestrição prévia ${ }^{42}$.

Catão conclui que a difamação é inevitável, e que, no conflito entre a necessidade da existência de leis de sedição e a liberdade de expressão, esta última deve ser favorecida, por ser um "bem maior", e pelo risco que uma lei de difamação abrangente geraria à manutenção de tal direito:

"I must own, that I would rather many Libels should Escape, then the Liberty of the Press should be infringed; yet no Man in England thinks worse of Libels than

\footnotetext{
40 TRENCHAND \& GORDON. Cato's Letters, or Essays on Liberty, Civil and Religious, and Other Importante Subjects. 1724. Apud: FELDMAN, Stephen. Op. cit., localização 141

${ }^{41}$ TRENCHAND \& GORDON. Cato's Letters, or Essays on Liberty, Civil and Religious, and Other Importante Subjects. 1724. Apud: CURTIS, Michael Kent. Op. cit., localização, 537-543

42 Idem.
} 
I do. (...) As long as there is such Things as Printing and Writing, there Will be Libels: It is an evil Arising out of a much greater good. ${ }^{43}$,

Como já observado acima, as Cartas de Catão tiveram grande influência nos Estados Unidos coloniais, influência esta que se prolongou no tempo, sendo as Cartas invocadas durante o debate em torno da Lei de Sedição de 1798, como se verá no item seguinte. Tal influencia dá continuidade ao desenvolvimento do pensamento político-filosófico a respeito do direito à liberdade de expressão. Ainda no âmbito inglês, no entanto, poucos filósofos serão tão influentes como John Stuart Mill, que traça uma defesa ao direito à liberdade de expressão em sua obra $A$ Liberdade, que passa agora a ser analisada.

John Stuart Mill escreve e publica A Liberdade muito após o período de Guerra Civil e interregnum britânico, já no contexto de uma monarquia constitucional, em 1859. Neste sentido, não é surpreendente que o capítulo da obra referente ao direito à liberdade de expressão seja iniciado com a constatação de que já se foi o tempo em que a defesa ao direito à liberdade de expressão era necessária como garantia contra governos autoritários que não representavam o povo. Mill reconhece que a lei britânica em si a respeito da liberdade de expressão não mudou, mas que haveria, no geral, se tornado "letra morta" $"$. Não obstante, o autor argumenta que, mesmo no caso de um governo de que fato representasse a vontade do povo, nenhum governo poderia suprimir ideias, mesmo que estas fossem minoritárias. Isto porque, segundo Mill, a sociedade, mesmo que soberana, não tem o poder de suprimir vozes dissidentes:

"If all mankind minus one, were of one opinion, and only one person were of the contrary opinion, mankind would be no more justified in silencing that one person than he, if he had the power, would be justified in silencing man kind. ${ }^{45,}$

Assim, Mill introduz o tema que irá guiar sua obra, e ampliar a doutrina já desenvolvida por Milton a respeito da importância de tolerância à opiniões dissidentes para a busca da verdade em uma sociedade. Neste

\footnotetext{
${ }^{43}$ Ibid. localização 537

${ }^{44}$ MILL, John Stuart. On Liberty and Other Essays. Edição de Kindle (Amazon), 1869, p. 13.

${ }^{45}$ Ibid. p. 13
} 
sentido, Mill argumentará que a supressão de uma opinião é um "mal peculiar", e que configura um "roubo à raça humana", sendo ainda pior para aqueles que com ela não concordam, uma vez que, caso a opinião esteja certa, estes perdem a oportunidade de mudar sua opinião errada, e, caso a opinião seja de fato errada, a verdade fica ainda mais clara em confronto a ela ${ }^{46}$.

Deste modo, Mill advoga a favor da expressão de uma maneira mais radical que Milton. Enquanto o primeiro tendia a defender expressões que fossem ao menos de uma mesma natureza ou similares às hegemônicas, Mill afirma que nunca podemos estar certos de que a opinião que estamos suprimindo é falsa, e, mesmo que estivéssemos certos que ela o fosse, suprimi-la seria um mal, uma vez que o confronto entre ideias pode tornar a verdade ainda mais aparente ${ }^{47}$. Mill então aponta para a falibilidade humana, e afirma:

"There is the greatest difference between presuming an opinion to be true, because, with every opportunity for contesting it, it has not been refuted, and assuming its truth for the purpose of not permitting its refutation. Complete liberty of contradicting and disproving our opinion, is the very condition which justifies us in assuming its truth for purpose of action; and on no other terms can a being with human faculties have any rational assurance of being right" ${ }^{48}$.

Neste sentido, o diálogo e o confronto de ideias é necessário para se chegar à verdade sobre tal questão. Uma ideia sem refutação, ou cuja refutação seja proibida, não é uma ideia legítima sobre a qual se possa basear uma conduta. Não se pode presumir estar certo sem a tentativa de dissidência sobre um tema. É possível retificar erros pela discussão, e a experiência, e apenas com uma aberta e ampla discussão na sociedade é possível construir uma real fundamentação para as diversas opiniões ${ }^{49}$.

Para Mill, no entanto, em uma argumentação ambígua com relação a sua constatação inicial, a sociedade britânica não era um local para a "liberdade mental", pela grande persecução da sociedade hegemônica a

\footnotetext{
${ }^{46}$ Idem.

${ }^{47}$ Ibid. p. 14

${ }^{48}$ Ibid. p. 16

${ }^{49}$ Ibid. p. 13.
} 
ideias dissidentes, tornadas maiores pelo estigma social de sanções penais ${ }^{50}$. Assim, Mill constata:

"For a long time past, the chief mischief of the legal penalties is that they strenghten the social stigma. It is that stigma which is really effective, and so effective is it, that the profession of opinions which are under the ban of society is much less common in England, than is, in many other countries, the avowal of whose which incur risk of judicial punishment" 51.

Assim como nas Cartas de Catão, Mill parece fazer alusão ao "chilling effect", isto é, ao efeito causado pela mera existência de punições legais à expressão crítica ou dissidente, o qual leva à autocensura de tal expressão.

É o debate aberto de diversas opiniões que historicamente levou à quebra de governos autoritários na Europa, e, segundo o autor, as maiores melhorias no pensamento e nas instituições humanas europeias ocorreram quando o despotismo mental impulsionado por governos tirânicos foi derrubado, sem que fosse substituído por outro igual. Também na linha de Milton de que uma harmonia seria criada da colisão de opiniões diversas, Stuart Mill irá afirmar que uma vida política saudável necessita de partidos a favor da estabilidade, e partidos a favor do progresso, assim como das mais diversas opiniões sobre assuntos públicos. Com um debate livre e aberto sobre todos os aspectos práticos da vida em sociedade, a verdade irá surgir; não de uma opinião absoluta, mas de verdades parciais em cada tipo de discurso. Neste sentido, "only through diversity of opinion is there, in the existing state of human intellect, a chance of fair play to all sides of the truth" 52 .

Ao final do capítulo, Start Mill argumenta um último ponto com relação ao limite ao poder de supressão pelo Estado de opiniões críticas, inclusive se estas forem tidas como ofensivas. Contra aqueles que afirmam que opiniões devem ser dadas de maneira moderada, não excedendo os limites de uma discussão justa, o autor constata que os limites do que é uma “discussão justa” ou uma "opinião moderada" não são claros. Neste sentido,

\footnotetext{
${ }^{50}$ Ibid. p. 22

${ }^{51}$ Ibid. p. 22

${ }^{52}$ Idem.
} 
Mill aponta que há uma tendência de se ver uma crítica como ofensiva sempre que esta é poderosa, ou que o crítico demonstra paixão sobre o tema $^{53}$.

Segundo Stuart Mill, seria até possível questionar a conduta daqueles que buscam suprimir fatos ou falsamente caracterizar elementos ao fazer uma crítica. No entanto, mesmo aqueles que assim o fazem, tendem a agir de boa-fé nestas ocasiões, sendo raramente adequada a caracterização de tal conduta como moralmente culpável. Menos ainda, conclui Mill, deveria a lei interferir com esse tipo controverso de infração ${ }^{54}$.

Nesta passagem, o autor parece novamente desenhar a fundamentação de um tema que seria desenvolvido posteriormente por tribunais, especialmente nos Estados Unidos: não se deve punir uma crítica ou expressão meramente por esta erroneamente caracterizar fatos. É dizer: a imputação de um fato falso a um indivíduo não é suficiente para a punição de quem o imputou; é preciso provar que tal pessoa não agiu de boa-fé, e tinha o dolo, isto é, sabia que tal fato era falso. Este pensamento será futuramente a base para a doutrina da real malícia, desenvolvida pela Suprema Corte americana.

Mill conclui com uma crítica à sociedade inglesa: no geral, as opiniões sobre as quais se pede moderação ao expressá-las são aquelas contra hegemônicas. As opiniões já comumente aceitas pela sociedade são comumente eivadas de retórica que poderia ser considerada ofensiva, a sociedade não critica tais expressões. Sobre se tais opiniões ofensivas deveriam ser restringidas, no entanto, Mill chega a uma conclusão ainda muito discutida nos dias de hoje: "It is, however, obvious that law and authority have no bussiness with restraining either" 55.

Enquanto Mill trouxe muitos avanços doutrinários a respeito da proteção do direito à liberdade de expressão na Inglaterra, a realidade prático-jurídico inglesa era outra, e o crime de difamação sediciosa, criado

\footnotetext{
${ }^{53}$ Ibid. p. 35

${ }^{54}$ Ibid. p. 35-36

${ }^{55}$ Ibid. p. 36
} 
pelo Star Chamber no século XVII, seguia em vigor. Juridicamente, e talvez pelo histórico do licenciamento prévio de publicações do país, a liberdade de expressão na Inglaterra era definida apenas como a proteção contra a censura prévia. Contanto que um cidadão pudesse falar o que pensava sem ser censurado anteriormente, as consequências ulterior caso se constatasse um "abuso" à liberdade de expressão poderiam ser severas. Neste sentido, a existência do crime de difamação sediciosa, isto é, da punição por discurso que tivesse uma "tendência malígna", ou que pudesse ser malicioso e ofensivo em relação ao governo ou a uma autoridade pública, não ofendia o direito à liberdade de expressão ${ }^{56}$.

O jurista William Blackstone, ao escrever seu tratado sobre o direito inglês em 1769, irá cristalizar esta doutrina, que por muitos autores contemporâneos é referida como, simplesmente, "Blackstone":

"In this, and the other instances which we have lately cosidered, where blasphemous, immoral, trasonable, schismatical, seditious or scandalous libels are punished by the English law, some with a greater, others with a lesser degree of severity, the liberty of the press, properly understood, is by no means violated. The liberty of the press is indeed essential to the nature of a free state: but this consists in laying no previous restraints upon publications, and not in freedom from censure for criminal matter when published. Every Freeman has an undoubted right to lay what sentiments he pleases before the public: to forbid this, is to destroy the freedom of the press: but if he publishes what is improper, mischievous, or illegal, he must take the consequence of his own temerity. ${ }^{57,}$

Segundo Blackstone, aquelas expressões que criticavam autoridades públicas tinham uma tendência imoral e perniciosa, e atuavam contra a paz pública, expondo pessoas públicas ao ódio da sociedade. Deste modo, a difamação de pessoas públicas deveria sempre ser punida (neste caso, por meio do crime de difamação sediciosa), mesmo que a expressão fosse verdadeira ou falsa, pois constituía em si um mal contra a sociedade ${ }^{58}$.

Com a herança de parte da common law inglesa, os Estados Unidos, mesmo consagrando abertamente o direito à liberdade de expressão em sua Constituição, irão aprovar, em 1798, uma lei criminalizando a sedição. Os

\footnotetext{
${ }^{56}$ LEWIS, Anthony. Op. cit., p. 1; CURTIS, Michael Kent. Op. cit., localização 86; FELDMAN, Stephen. Op. cit., localização 137

${ }^{57}$ BLACKSTONE, William. Commentaries on the Laws of England, 1769. Apud: CURTIS, Michael Kent. Op. cit., localização 605-609

${ }^{58}$ LEWIS, Anthony. Op. cit., p. 3; FELDMAN, Stephen. Op. cit., localização 141.
} 
debates políticos ocorridos antes, durante e após a vigência da lei, servirão de base para a forte proteção do direito à crítica a governantes e a assuntos públicos, definitivamente consagrada pelo direito americano no caso $\mathrm{New}$ York Times v. Sullivan, e posteriormente exportada para diversos ordenamentos jurídicos nacionais e internacionais, onde exerce forte influência até hoje. É o que analisaremos no item a seguir.

\section{Os Estados Unidos e a Lei de Difamação Sediciosa de 1798}

Como já ressaltado anteriormente, os Estado Unidos preservaram muito do ordenamento jurídico inglês na aplicação de sua common law, inclusive as restrições ao direito à liberdade de expressão trazida pela punição ao discurso que pudesse ser considerado sedicioso. Assim, mesmo com a consagração do direito à liberdade de expressão em textos legais, e inclusive nas constituições dos estados e na Primeira Emenda, era possível encontrar na sociedade americana colonial e também após a independência, processos criminais com base no crime de difamação sediciosa ${ }^{59}$.

No entanto, mesmo as autoridades britânicas da sociedade americana colonial já demonstravam maior tolerância a críticas, as quais se intensificaram com a gradual perda de respeito por autoridades inglesas pelos americanos, já no final do século XVII ${ }^{60}$. Ao contrário do contexto inglês, neste período os processos com base no crime de difamação por sedição não tinham como fundamentação a proteção da ordem e da paz social ou a necessidade de manutenção da dignidade de autoridades públicas, como afirmava Blackstone, mas sim a ideia de proteção do Governo contra um perigo real e imediato gerado pelo discurso crítico ${ }^{61}$.

Um dos maiores exemplos da divergência entre o sentimento da sociedade americana a respeito da liberdade de expressão e o que previa a

\footnotetext{
${ }^{59}$ FELDMAN, Stephen. Op. cit., localização 160-165

${ }^{60}$ Ibid. localização 175.

${ }^{61}$ Ibid. localização 189
} 
common law inglesa foi o julgamento de John Peter Zenger pelo crime de difamação sediciosa em 1735, por fazer críticas ao governador de Nova Iorque. $\mathrm{O}$ caso é tido por Lewis como o primeiro verdadeiro teste sobre o direito à liberdade de expressão nos Estados $\operatorname{Unidos}^{62}$. No julgamento, o advogado de Zenger não negou que as críticas tinham sido realizadas por seu cliente, mas pediu ao júri que, caso considerassem que as críticas eram verdadeiras, absolvessem o réu. Apesar do juiz que presidia o julgamento avisar ao júri que a verdade não era uma defesa válida para o crime de difamação sediciosa, o júri mesmo assim o absolveu. A decisão do caso foi divulgada por todas as colônias americanas, e até a Independência não houve mais nos Estados Unidos qualquer condenação pelo crime de difamação sediciosa ${ }^{63}$.

A falta de condenações foi também resultado do crescimento de sentimentos revolucionários contra a coroa inglesa, que obstaram todas as tentativas de processo criminal pelas autoridades públicas com base em tais críticas, sendo a própria tentativa de supressão a razão para a grande valorização do direito à liberdade de expressão pela sociedade americana. Republicações das Cartas de Catão da imprensa americana nesta época eram comuns, assim como a propagação da ideia de que o direito à liberdade de expressão era o guardião da liberdade ${ }^{64}$. No entanto, quando se tratava de expressão pró-Inglaterra, a sociedade americana não era tão tolerante, e buscava suprimi-la com base na ideia de que tais expressões causariam mal à sociedade ${ }^{65}$.

Com a Independência americana e a adoção da Constituição, os Estados Unidos consagraram o direito à liberdade de expressão na Primeira Emenda, sem, no entanto, que os constituintes realizassem qualquer debate substancial naquele contexto sobre o que tal direito significaria, e se protegeria a liberdade de expressão mais do que apenas contra a censura

\footnotetext{
${ }^{62}$ LEWIS, Anthony. Op. cit., p. 3; CURTIS, Michael Kent. Op. cit., localização 547

${ }^{63}$ LEWIS, Anthony. Op. cit., p. 4; FELDMAN, Stephen. Op. cit., localização 192

${ }^{64}$ CURTIS, Michael Kent. Op. cit., localização 622

${ }^{65}$ FELDMAN, Stephen. Op. cit., localização 201
} 
prévia, ou seja, se iria além da doutrina de Blackstone ${ }^{66}$. Não obstante, a adoção da Primeira Emenda deu à sociedade americana mais um instrumento para ser utilizado contra esforços pelo governo de supressão da expressão dissidente. $\mathrm{O}$ primeiro teste que colocaria à prova a real extensão do direito à liberdade de expressão e a possibilidade de sua utilização para criticar autoridade públicas virá com a aprovação da Lei de Difamação Sediciosa, de $1798^{67}$.

Kent Curtis, citando o jurista Harry Kalven, alega que a Lei de Sedição de 1798 é um paradigma na discussão do direito à liberdade de expressão, e que os debates travados no contexto de sua aprovação e vigência demonstram o papel central da liberdade de expressão em uma sociedade democrática ${ }^{68}$. Naquele contexto, duas questões vitais foram levantadas: a crítica ao governo, a advocacia de políticas públicas, e a crítica à forma como autoridades públicas agiam deveriam ser crimes na sociedade americana? E, neste viés, o cidadão em uma democracia tem como papel adicional ao de eleger seus representantes também o papel de analisar a conduta dos mesmos?

À época da aprovação da lei, este debate sobre o papel da sociedade em uma democracia republicana estava sendo travado entre as facções Federalista e Republicana no Congresso americano. Por um lado, a democracia republicana americana do século XVIII era baseada na ideia de que cidadãos de virtude seriam eleitos os representantes do povo, e trabalhariam de maneira conjunta no Congresso para o alcance do bem comum. Deste modo, o direito de sufrágio deveria ser restrito àqueles cidadãos que, por serem virtuosos, teriam a capacidade de eleger dentre eles os homens mais virtuosos para os representar, apenas assim garantindo que os representantes não seriam passíveis de corrupção, e trabalhariam para alcançar o bem comum. Diante deste cenário, os Federalistas americanos argumentavam que, a partir do momento em que o povo soberano elegia um

\footnotetext{
${ }^{66}$ LEWIS, Anthony. Op. cit., p. 9; FELDMAN, Stephen. Op. cit., localização 876, 995.

${ }^{67}$ LEWIS, Anthony. Op. cit., p. 9.

${ }^{68}$ CURTIS, Michael Kent. Op. cit., localização 1528
} 
representante, criticar as ações deste representante iria contra o governo republicano, e era uma traição contra o povo. Por outro lado, aqueles que se identificavam como Republicanos alegavam que, como o povo é soberano, deveria ter total liberdade para debater políticas públicas adotadas por seus representantes ${ }^{69}$.

Tanto Federalistas quanto Republicanos viam um ao outro como querendo destruir a sociedade americana: a própria ideia da existência de uma oposição forte dentro do Congresso pelos Republicanos era vista pelos Federalistas como anti-democrática, uma vez que todos deveriam trabalhar juntos pelo bem comum, e não se opor uns aos outros (naquela época, a existência de partidos políticos ainda não era uma ideia aceita) ${ }^{70}$. Aqueles que praticavam a oposição, portanto, estavam atuando contra a paz, a ordem, e a sociedade em si. Já os Republicanos acreditavam que os Federalistas eram secretamente monarquistas e autoritários, e agiam de uma forma anti-democrática ao não permitir ao povo soberano o direito de crítica sobre medidas adotadas ${ }^{71}$.

As tensões existentes entre as facções se exacerbaram ainda mais quando a Revolução Francesa - que havia sido inicialmente apoiada pelos revolucionários americanos - se converteu no terror e caos jacobino. Os Republicanos eram vistos pelos Federalistas como amantes dos franceses, e apoiadores de uma democracia desordenada com diversas facções, que iria destruir o governo republicano dos Estados Unidos. Tornando a tensão entre os países ainda maior, em 1798 os franceses passaram a atacar navios americanos após a celebração de um tratado entre os Estados Unidos e a Inglaterra. Os franceses ofenderam ainda mais os americanos após uma tentativa de solicitar, dos representantes americanos enviados à França para tratar dos ataques aos navios, um empréstimo, uma quantia como suborno, e a retificação de um discurso do Presidente Adams $^{72}$. Começa então neste

\footnotetext{
${ }^{69}$ FELDMAN, Stephen. Op. cit., localização 332

${ }^{70}$ Ibid. localização 787

${ }^{71}$ Ibid. localização 778

${ }^{72}$ CURTIS, Michael Kent. Op. cit., localização 801; LEWIS, Anthony. Op. cit., p. 11
} 
período uma guerra não declarada entre os Estados Unidos e a França, e a oposição ao governo -- que já não era vista pelo Federalistas como válida em uma República - passa a ser tida também como desleal. Um jornal federalista da época, em uma matéria publicada logo após aprovação da Lei de Sedição, ilustra bem as razões que motivaram sua aprovação neste contexto:

"Qualquer americano que seja amigo da presente administração do governo americano é sem dúvida um verdadeiro republicano, um verdadeiro patriota: pois a administração é, necessariamente, eleita por umamaioria do povo (...) Qualquer americano que se oponha à administração é um anarquista, um jacobino, e um traidor. Se homens não gostam dos presentes oficiais de nosso governo, que votem em outros nas próximas eleições... É patriotismo escrever em favor de nosso governo; é sedição escrever contra ele. ${ }^{73 "}$

É neste clima político que a Lei de Difamação Sediciosa de 1798 é aprovada pelo Congresso Americano controlado pelos Federalistas (todos os republicanos votaram contra a lei). A lei tipificou o crime de difamação sediciosa como:

"Escrever, imprimir, falar, ou publicar (...) quaisquer escritos falsos, escandalosos ou maliciosos contra o governo dos Estados Unidos, ou qualquer câmara do Congresso dos Estados Unidos, ou o Presidente dos Estados Unidos, com a intenção de difamar (...) ou de contra eles, ou qualquer deles, criar desprezo ou descrédito, ou de incitar contra (...) qualquer um deles o ódio do bom povo dos Estados Unidos. ${ }^{74,}$

O caráter extremamente político da lei fica claro com a exclusão da proteção legal do Vice-Presidente, (na época, Thomas Jefferson, um Republicano) e também com a data de validade da mesma, que iria expirar no ano de 1801, no último dia do mandato do Presidente Adams. A lei trazia a possibilidade da prova da verdade das expressões sediciosas, sendo portanto mais protetiva do que a common law inglesa. No entanto, como ressaltaram os republicanos na época, a grande maioria das expressões processadas se tratavam de opiniões, e não de fatos que pudessem ser

\footnotetext{
${ }^{73}$ CURTIS, Michael Kent. Op. cit., localização 822

${ }^{74}$ CURTIS, Michael Kent. Op. cit., localização 845, LEWIS, Anthony. Op. cit., p. 11; FELDMAN, Stephen. Op. cit., localização 1135. Ver também: Sedition Act, aprovado em 14 de julho de 1798. Disponível em: < http://www.constitution.org/rf/sedition 1798.htm>. Acesso 8 de novembro 2012.
} 
provados verdadeiros, o que tornava a proteção da "exceção da verdade" praticamente nula ${ }^{75}$.

$\mathrm{O}$ autor Feldman, em seu livro Free Expression and Democracy in America, descreve a aprovação da Lei de Sedição como o Big Bang: todas as ambiguidades existentes na sociedade americana até então sobre a extensão do direito à liberdade de expressão explodiram na discussão política entre federalistas e republicanos, e, neste contexto, finalmente se começa uma real tentativa de uma definição mais elaborada do direito à liberdade de expressão ${ }^{76}$.

Da perspectiva dos federalistas, a restrição do direito à liberdade de expressão pelo crime de difamação sediciosa era uma forma de proteção do bem comum, pois a propagação de ideias falsas contra os representantes do povo pelos Republicanos encorajaria uma rebelião contra o governo ${ }^{77}$. Assim, Gray Otis, um congressista federalista, justificava a lei de difamação sediciosa - isto é, a criminalização da crítica contra o Congresso e o Presidente - como o exercício legítimo do poder do governo de se $\operatorname{proteger}^{78}$. Também neste viés, John Marshall, federalista de Virginia, argumentando contra James Madison, afirma que a sedição contra o governo é uma injúria contra o próprio povo, uma vez que, em uma república, o interesse do povo e o interesse do governo são os mesmos ${ }^{79}$.

Marshall ainda irá propagar um segundo ponto da fundamentação federalista a favor da lei difamação sediciosa. Respondendo a críticas republicanas de que a lei seria violatória do direito à liberdade de expressão, o congressista, ecoando a doutrina de Blackwell, retoma a ideia de que a liberdade de expressão é apenas a liberdade de publicação sem censura prévia, e não "a liberdade de espalhar com impunidade difamações falsas e escandalosas que possam destruir a paz e mutilar a reputação de um

75 CURTIS, Michael Kent. Op. cit., localização 845, LEWIS, Anthony. Op. cit., p. 11; FELDMAN, Stephen. Op. cit., localização 1135

${ }^{76}$ Ibid. localização 1140

${ }^{77}$ Ibid. localização 1156

${ }^{78}$ CURTIS, Michael Kent. Op. cit., localização 862

${ }^{79}$ FELDMAN, Stephen. Op. cit., localização 1128 
indivíduo ou de uma comunidade" ${ }^{180}$. Neste sentido, federalistas alegavam que a liberdade de expressão não pode incluir o abuso da mesma, e deve ser limitada pela proteção de outros direitos ${ }^{81}$. O representante Robert Goodloe, também exemplificava este viés do pensamento federalista:

"Todo homem pode publicar o que quiser; mas se ele abusar desta liberdade de modo a publicar [slanders]* contra seu próximo, ou [libels] falsos, escandalosos ou maliciosos contra magistrados, ou contra o governo, ele poderá ser punido" ${ }^{82}$.

Os republicanos, por sua vez, irão atacar a lei de difamação sediciosa em diversos aspectos, e é através do estudo de publicações dos principais autores republicanos da época que é possível encontrar o desenvolvimento de doutrinas e argumentos que formam até hoje a base da proteção do direito à liberdade de expressão em casos de difamação nos Estados Unidos e em alguns lugares do mundo, como se verá no capítulo II.

Inicialmente, é importante ter em mente que os primeiros argumentos traçados contra a lei não eram per se contra sua ratio (isto é, contra a proibição da crítica contra o governo por leis que criminalizavam a difamação sediciosa), mas sim argumentos de cunho jurisdicional: a Constituição dos Estados Unidos não dava ao governo federal o poder de limitar a liberdade de expressão, e apenas os estados da Federação poderiam emitir este tipo de leis. No entanto, conforme o debate sobre a lei se propagou, e republicanos foram processados por críticas feitas a autoridades públicas, novos argumentos mais sofisticados contra a lei foram sendo desenvolvidos, desta vez com base na proteção do direito à liberdade de expressão ${ }^{83}$. É nesta época também que as Cartas de Catão voltam a ser constantemente republicadas na imprensa americana, e muitas de suas ideias voltam a ser reproduzidas por líderes republicanos ${ }^{84}$.

Dentre estas figuras de liderança republicanas estão os deputados Albert Gallatin e John Nicholas, ambos os quais irão ter importantes declarações em sua atuação política contra a lei, baseadas na premissa das

\footnotetext{
${ }^{80}$ Ibid. localização 1234

${ }^{81}$ LEWIS, Anthony. Op. cit., p. 23

${ }^{82}$ CURTIS, Michael Kent. Op. cit., localização 878 (tradução livre).

${ }^{83}$ FELDMAN, Stephen. Op. cit., localização 1179

${ }^{84}$ CURTIS, Michael Kent. Op. cit., localização 1013
} 
Cartas de Catão de que um governo livre demanda a livre expressão, de modo que seja possível a participação popular informada, isto é, com acesso tanto a discursos críticos como discursos a favor de autoridades públicas. Neste sentido, Gallatin irá reafirmar o caráter político da lei de sedição, que tornava os críticos ao governo "inimigos do da Constituição", assim restringindo a soberania e participação popular pelo sufrágio:

"Se se colocar a imprensa sob qualquer restrição no que concerne as medidas de membros do governo; se assim se priva o povo dos meios de obter informação sobre sua conduta, com efeito se rende nulo seu direito de eleger representantes; e esta lei tem de ser considerada somente como uma arma utilizada por um partido atualmente no poder para perpetuar sua autoridade e preservar sua atual posição. ${ }^{85 "}$

Ainda traçando a conexão entre a lei de 1798 e a supressão do povo, Gallatin constata que o início das chamadas leis de difamação política (political libel) é autoritário, provindo desde o Império Romano, e, mais recentemente, do Star Chamber inglês. A resposta para discursos falsos, argumenta o deputado, não é a criminalização da difamação, mas um contra-discurso verdadeiro. Ter como a única solução para combater uma falsidade a punição, argumenta Gallatin, é uma confissão de que tal falsidade não pode ser combatida de nenhuma outra forma. Sendo assim, Gallatin também se utiliza da premissa de John Milton sobre o poder da verdade em um mercado de ideias, e faz alusão ao atual direito de resposta ao afirmar que a criminalização não é o método adequado para combater uma expressão falsa, mas sim o é a própria expressão ${ }^{86}$.

Gallatin, como muitos republicanos, também rejeita a doutrina de Blackwell, afirmando ser "disparatado dizer que punir um certo ato não constitui uma limitação à liberdade de exercer tal ato ${ }^{87 "}$. Para Gallatin, a aplicação de Blackwell no contexto americano de liberdade de expressão era absurdo, pois era claro que a censura prévia não era possível em se

\footnotetext{
${ }^{85}$ FELDMAN, Stephen. Op. cit., localização 1177 (tradução livre).

${ }^{86}$ CURTIS, Michael Kent. Op. cit., localização 951

${ }^{87}$ LEWIS, Anthony. Op. cit., p. 16
} 
tratando da fala, uma vez que o governo não iria "cortar a língua" de seus habitantes ${ }^{88}$.

Também invocando o viés autoritário da lei considerando a necessidade da liberdade de expressão e da participação popular em uma democracia, John Nicholas difere os Estados Unidos da Inglaterra uma vez que no contexto inglês as autoridades públicas eram apenas uma extensão do poder do Monarca, o qual não poderia ter uma conduta errada, por seu poder ser hereditário. No entanto, no contexto americano, as autoridades públicas estão subordinadas ao povo, e, consequentemente, respondem a ele $^{89}$.

Nicholas ainda reconhece o "chilling effect", isto é, a auto censura, que tal lei poderia gerar na sociedade:

"Se esta proposta se transformar em lei, o povo será privado de informação sobre
medidas públicas, a quel tem ele direito de receber, e a qual é a vida e o apoio de
um governo livre; pois, se editores forem sujeitos a persecução por cada
parágrafo que aparece em seus papeis, que o olhar de um governo ciumento pode
distorcer em ofensa contra esta lei, e adicionar as duras penas aqui previstas, não
se pode esperar que eles exerçam a liberdade e o espírito que se desejaria que os
motivasse (...) eles não só se absterão de publicar qualquer coisa de natureza
minimamente questionável, mas temeriam publicar a verdade, pois, ainda que
verdade, pode não estar sempre a seu alcance estabelecer a verdade de modo a
satisfazer uma corte de justiça. Esta lei, portanto, agiria para a supressão de toda
impressora no país que não for agradável à vontade do governo" James Madison, uma das principais lideranças republicana à época nos Estados Unidos, será também um dos mais influentes políticos nos debates travados durante a vigência da lei de sedição. Madison batalhou pela aprovação de uma resolução de sua autoria pelo Congresso do Estado de Virginia condenando a aprovação da Lei de Sedição ${ }^{91}$. A chamada Resolução de Virginia denuncia a lei como uma violação da Constituição americana, e proclama a existência de um "direito de livremente examinar pessoas e medidas públicas, e de livre comunicação entre pessoas na esfera

\footnotetext{
${ }^{88}$ LEWIS, Anthony. Op. cit., p. 16

${ }^{89}$ LEWIS, Anthony. Op. cit., p. 17

${ }^{90}$ CURTIS, Michael Kent. Op. cit., localização 914

${ }^{91}$ LEWIS, Anthony. Op. cit., p. 17
} 
pública" ${ }^{92}$ A Resolução coloca ainda este direito à análise de autoridades públicas como " o único guardião eficaz de todos os outros direitos"93. Segundo Anthony Lewis, este direito não apenas à liberdade de expressão mas à discussão sobre autoridades públicas é a premissa do sistema político americano, chamada por Lewis de "premissa Madisoniana" 94.

Apesar de inicialmente adotar o argumento jurisdicional, respondendo a críticas à Resolução de Virginia, Madison desenvolve argumentos ainda mais protetores da liberdade de expressão em seu Relatório sobre as Resoluções de Virginia, de 1800.

No Relatório, Madison, como Nicholas, irá rejeitar a doutrina de Blackwell, e afirmando que a punição prevista pela common law inglesa da difamação sediciosa não pode ser aceita como a ideia americana de liberdade de expressão. Para Madison, enquanto a Inglaterra funciona por um sistema em que se procura apenas limitar o poder do Monarca, o Parlamento inglês não possui limitações a suas atribuições. Já nos Estados Unidos, observa Madison, a soberania é do povo, que impões limites tanto ao Poder Executivo como ao Poder Legislativo ${ }^{95}$. Deste modo, a forma de governo adotada pelos dois países irá engendrar definições distintas à liberdade de expressão: na Inglaterra, onde o sistema de censura prévia era estabelecido originalmente pelo Rei, a proteção à liberdade de expressão se resumia a este campo; nos Estados Unidos, onde o Poder Legislativo era subordinado ao povo, a lei não poderia punir a expressão crítica ao governo. Assim, a liberdade de pensamento deve estar protegida "não somente da inspeção prévia de licenciadores, mas também da punição subsequente da lei" "96, uma vez que a punição posterior terá um efeito similar ao da censura prévia, fazendo com a lógica de Blackwell não deva ser aplicada:

\footnotetext{
92 MADISON, James. Virginia Resolution. 1798. Disponível em: <http://www.let.rug.nl/usa/documents/1786-1800/virginia-resolution-1798.php>. Acesso em 8 de nobembro de 2012 .

${ }^{93}$ Idem.

${ }^{94}$ LEWIS, Anthony. Op. cit., p. 18

${ }^{95}$ LEWIS, Anthony. Op. cit., p. 18

${ }^{96}$ CURTIS, Michael Kent. Op. cit., localização 1280
} 
"Uma lei que inflija penalidades a publicações impressas teria um efeito similar a uma lei autorizando uma restrição prévia às mesmas. Pareceria tolice falar que nenhuma lei impedindo a criação de publicações deve ser aprovada, mas que podem-se aprovar leis punindo-as caso sejam criadas ${ }^{97 " .}$.

Madison aponta ainda para a tradição da imprensa americana de análise da conduta de pessoas públicas, realizando tanto críticas como elogios, independemente da common law inglesa, o que na prática redefiniu os limites da liberdade de expressão para a sociedade americana ${ }^{98}$.

A respeito das disposições da lei em si, Madison também ressalta seu caráter político, alegando que a lei iria ser usada para manter os federalistas no poder ao calar a oposição. Além disso, a difamação sediciosa pode abarcar tanto questões de fato quanto opiniões, e estas últimas não poderiam ser provadas em um tribunal ${ }^{99}$. Madison conclui que, contra os inevitáveis abusos da liberdade de expressão, autoridades públicas poderiam buscar remédios civis, mas não criminais ${ }^{100}$.

Outros pensadores da época foram impulsionados pelos escritos de Madison, e se manifestaram contra a lei. Em 1800, o advogado Tunis Wortman publica sua obra A Treatise Concerning Political Enquiry and the Liberty of the Press, onde retoma a ideia Miltoniana de que a verdade irá prevalecer em uma argumentação, sendo a própria expressão, e não a coerção, a forma adequada para a formação ou mudança de uma opinião ${ }^{101}$.

Wortman argumenta que a interferência do Governo com a liberdade de expressão leva a abusos, e a vontade política de supressão de uma expressão falsa não nasce de um compromisso com a justiça, mas sim da vontade de suprimir de opiniões contrárias a seus objetivos. Para Wortman, o direito penal é um instrumento do poder, e pode ser utilizado por um governo "para o propósito de esmagar indivíduos cujas opiniões são vistas como odiosas"102.

\footnotetext{
${ }^{97}$ FELDMAN, Stephen. Op. cit., localização 1304

${ }^{98}$ Ibid. localização 1309-1313

${ }^{99}$ CURTIS, Michael Kent. Op. cit., localização 1293

${ }^{100}$ FELDMAN, Stephen. Op. cit., localização 1323

${ }^{101}$ CURTIS, Michael Kent. Op. cit., localização 1304

${ }^{102}$ Ibid. localização 1320
} 
Na linha de Madison e Nicholas, Wortman argumenta que a persecução criminal é um produto da monarquia, e não cabe em uma democracia republicana, na qual o governo deve responder à opinião pública. Neste sentido, a persecução criminal da expressão é mais perigosa do que a falsidade que se quer punir, uma vez que a liberdade de investigar a conduta de governantes é um requisito necessário para a proteção contra abusos de autoridades ${ }^{103}$.

Assim como Gallatin, Wortman irá alegar que a liberdade de análise crítica ao governo é necessária para o exercício do direito de voto, e, na linha de Nicholas, também irá prever o efeito congelador que tal lei poderia ter no discurso, e a insegurança que a ampla definição de sedição traz:

"[S]eja a tendência contínua de tal sistema de temperar o ardor de envolvimento em política, e de inspirar a mente com terror. A investigação de medidas públicas vai incessantemente ser associada com o terror de persecuções e penalidades... em vão tentaremos estimar a extensão precisa da proibição, ou verificar o que podemos falar, e até que ponto somos compelidos ao silêncio. ${ }^{104}$.

Finalmente, é preciso ainda mencionar o republicano John Thomson, que, em An Enquiry Concerning the Liberty and Licentioiusness of the Press, desenvolveu um argumento contra a lei de sedição baseado tanto na Constituição americana como na democracia. Segundo Thomson, uma vez que a constituição protegia claramente o direito dos representantes do povo de liberdade absoluta de expressão no Congresso, o direito à liberdade de expressão do próprio povo soberano não poderia ser restrito por aqueles que são seus representantes, e muito menos deveriam tais representantes gozar de maior liberdade do que seus representados. Neste sentido, Thomson caracteriza aqueles que buscam definir o que seria o "abuso" da liberdade de expressão como figuras autoritárias e pouco tolerantes de opiniões contrárias às suas ${ }^{105}$.

Repetindo também a premissa de Milton de que a verdade é mais forte do que a falsidade, Thomson afirmou que medidas coercitivas não deveriam ser utilizadas, uma vez que a coerção apenas silencia, e não

\footnotetext{
${ }^{103}$ Ibid. localização 1329

${ }^{104}$ Ibid. localização 1329-1333

${ }^{105}$ Ibid. localização 1339
} 
convence. Apesar de anterior a Mill, Thomson argumenta que mesmo discursos falsos ou errôneos podem contribuir com a verdade, a tornando mais clara em comparação ${ }^{106}$.

Em suma, o que se pode observar das reflexões dos republicanos Gallantin, Nicholas, Madison, Wortman e Thomson é o início de uma fundamentação inicialmente político-fisolófica, mas que posteriormente irá se tornar jurídica, para a proteção especial do direito à liberdade de expressão no que tange a crítica a autoridades públicas e a opinião sobre assuntos públicos. Com a constante constatação de que o crime de difamação sediciosa - que especialmente protege figuras públicas - é de uma natureza autoritária e tem sua origem moderna na monarquia inglesa, estes pensadores constatam que a democracia representativa republicana não é compatível com tal figura legal. Segundo estes autores, o crime de sedição: restringe a possibilidade do exercício do direito de participação popular na democracia republicana por não permitir uma análise crítica da sociedade sobre seus governantes e da sociedade às mesmas, o que atenta contra a soberania do povo; causa um efeito de autocensura na imprensa e na sociedade em geral, que deixa de publicar informações mesmo que verdadeiras pelo caráter vago da lei ou pela impossibilidade de provar sua verdade em um tribunal; e é inadequado para a busca da verdade ou a correção de uma informação falsa, uma vez que é apenas com a contraexpressão sobre a questão que o convencimento de alguém sobre o tema é possível.

Não é por acaso que as fontes aqui citadas do debate sobre a lei de sedição são todas de natureza política ou acadêmica. Serão quase dois séculos até que a doutrina jurídica americana, pioneira na defesa da liberdade de pensamento, se consolide definitivamente a favor de uma maior proteção para expressão crítica de figuras públicas com base em sua importância para a democracia. De fato, a constitucionalidade da lei de sedição nunca foi questionada pelos tribunais na época de sua vigência, e os 
próprios juízes da Suprema Corte americana na época presidiram os julgamentos levados a cabo com base na lei ${ }^{107}$. A título de exemplo, no julgamento de Thomas Cooper, um jornalista que havia criticado o Presidente Adams, o Magistrado Chase da Suprema Corte americana reafirmou a importância da lei na medida em que protegia o governo:

"Se um homem tenta destruir a confiança do povo em seus governantes, seu magistrado supremo, e sua legislatura, ele efetivamente mina a fundação do governo. Um governo republicano somente pode ser destruído em duas formas; a introdução da luxúria e a licenciosidade da imprensa" ${ }^{108}$.

Em sua conta final, a lei de sedição gerou quatorze convicções, todas contra republicanos, com a estipulação de penas de prisão e multas em ao menos treze destas ${ }^{109}$. Muitas das expressões processadas não diziam respeito a fatos, e sim a opiniões, como por exemplo no caso de Matthew Lyon, que chamou o Presidente de "pomposo" e "tolo"110. No entanto, a lei de sedição foi um desastre político para os federalistas, quando, na eleição de 1800, o republicano Thomas Jefferson assumiu a presidência e os republicanos tomaram o controle do Congresso. Ao assumir o cargo de Presidente, Jefferson perdoou legalmente todos aqueles condenados pelo crime de difamação sediciosa ${ }^{111}$.

Quando Alexis Tocqueville observa os Estados Unidos, em 1835, em sua obra Democracia na América, processos criminais por difamação sediciosa haviam se tornado cada vez mais $\operatorname{raros}^{112}$. De fato, uma corte em Virginia em 1912 constatou que o último caso por difamação criminal julgado no Estado havia sido em $1811^{113}$. Segundo Feldman, as principais razões para o extremo declínio em processos desta natureza seriam três: a falta de uma vantagem política em buscar este tipo de persecuções (já demonstrada pela reação social à lei de 1798); a melhoria nas tecnologias

\footnotetext{
${ }^{107}$ LEWIS, Anthony. Op. cit., p. 15

${ }^{108}$ FELDMAN, Stephen. Op. cit., localização 1201 e 1286

${ }^{109}$ Ibid. localização 1240

${ }^{110}$ CURTIS, Michael Kent. Op. cit., localização 1334

${ }^{111}$ CURTIS, Michael Kent. Op. cit., localização 1329; Lewis 20; FELDMAN, Stephen. Op. cit., localização 1428 .

112 DE TOCQUEVILlE, Alexis. Democracy in America. Volume um. Edição do Kindle (Amazon). Domínio público, 1835, p. 145.

${ }^{113}$ CURTIS, Michael Kent. Op. cit., localização 1528;
} 
das máquinas de impressão que tornou a publicação de jornais mais barata, e consequentemente a maior diversidade e disponibilidade de publicações, que tinham mais facilidade para criticar e combater as críticas realizadas sobre questões públicas; e o surgimento do sistema bipartidário no início do século XVIII, que tornou a crítica política comum e aceitável socialmente, e não mais como algo que estaria destruindo a unidade da república na luta por um bem comum ${ }^{114}$.

Neste sentido, Tocqueville constatou a importância e abundância da diversidade da imprensa americana, assim como o caráter crítico e ofensivo de suas publicações. Segundo Tocqueville, em um país como os Estados Unidos no qual o povo é soberano, a censura da imprensa é uma noção absurda:

"Quando o direito de todo cidadão de co-operar no governo de uma sociedade é reconhecido, todo cidadão pode ser presumido possuidor de poder para discriminar entre as diferentes opiniões de seus contemporâneos, e de apreciar o fato diverso de que inferências podem ser derivadas. A soberania do povo e a liberdade da imprensa podem portanto ser observadas como institutos correlatos; assim como a censura da imprensa e o sufrágio universal são duas coisas irreconciliavelmente opostas (...)"115.

Tocquevile observa a falta de processos criminais por publicações críticas, chegando a afirmar que nenhum indivíduo se atreveria em impor restrições à liberdade de expressão, uma vez que os estadunidenses aplicavam a doutrina da soberania do povo com "perfeita consistência" 116. Para Tocqueville, a supressão ao direito à liberdade de expressão nos Estados Unidos ocorria pela opinião pública propagada pela imprensa, e a consequente pressão exercida contra visões minoritárias, mas não mais pelas Cortes, ou pelo direito penal ${ }^{117}$.

Já em 1840, o Congresso Nacional aprovou uma lei para restituir a multa cominada contra Matthew Lyon, primeira pessoa processada com base na lei de sedição, a seus herdeiros. Lyon havia se tornado um mártir pela liberdade de expressão após sua condenação, sendo inclusive reeleito

\footnotetext{
${ }^{114}$ FELDMAN, Stephen. Op. cit., localização 1676

${ }^{115}$ DE TOCQUEVILLE, Alexis. Op. cit., p. 144

${ }^{116}$ Ibid. p. 145

${ }^{117}$ Ibid. p. 148
} 
deputado enquanto cumpria pena pelo crime. No relatório do Comitê do Congresso que analisava a proposta de lei para restituir a multa, os deputados constataram que a lei de difamação sediciosa era nula, uma vez que foi aprovada pelo Congresso com base em um poder que não the havia sido delegado. Em uma votação de 124 a 15, o Congresso determinou a restituição da multa à família de Lyon, em uma tentativa de deixar claro o mandato da Constituição contra a supressão da liberdade de expressão ${ }^{118}$.

Em um último capítulo da história referente à Lei de Sedição de 1798, em 1964, quase duzentos anos após sua aprovação, a Suprema Corte americana finalmente irá declarar, de maneira simbólica, a lei de sedição inconstitucional. A doutrina legal que fundamentou tal inconstitucionalidade foi inicialmente desenvolvida no caso New York Times v. Sullivan, e protege a expressão crítica de figuras públicas. Esta doutrina terá influência no direito internacional dos direitos humanos e no direito comparado, sendo também posteriormente reproduzida em diversos casos e documentos. É o que se passa a ver no capítulo 2.

${ }^{118}$ CURTIS, Michael Kent. Op. cit., localização 1126 


\section{Capítulo II: Parâmetros de direito internacional e comparado sobre o direito à crítica}

\section{A Jurisprudência da Suprema Corte dos Estados Unidos}

A jurisprudência da Suprema Corte dos Estados Unidos a respeito do direito à liberdade de expressão influenciou e segue influenciando diversos países e órgãos internacionais no mundo. A ampla proteção à expressão garantida pela Primeira Emenda da Constituição americana abarca desde expressões dissidentes, a opiniões ofensivas, e até mesmo odiosas, com base nos parâmetros desenvolvidos pela Suprema Corte americana a respeito do que constitui tal direito e quais são os seus limites. No entanto, e como foi verificado no capítulo 1 no âmbito do debate sobre a Lei de Difamação Sediciosa, a posição jurídica da Suprema Corte americana não foi sempre protetora da expressão. Pelo contrário: os próprios juízes da Suprema Corte americana presidiram os julgamentos que condenaram republicanos por suas opiniões críticas ao governo.

\section{1.a As opiniões dissidentes dos Magistrados Holmes e Brandeis}

De fato, é apenas em 1919 que um juiz da Suprema Corte americana irá pela primeira vez apoiar um caso a favor do direito à liberdade de expressão em um voto dissidente, no caso Abrams v. United States ${ }^{119}$. Até então, a Suprema Corte seguia adotando a ideia de que qualquer discurso com uma "tendência malígna" poderia ser punido, aplicando a doutrina de Blackstone $^{120}$. Magistrado Holmes, autor do voto, havia previamente confirmado a condenação de réus em três casos similares envolvendo a aplicação da Lei de Espionagem, uma lei aprovada no âmbito da primeira guerra mundial que tornava ilegal "a mais inócua crítica ao governo ou à

\footnotetext{
${ }^{119}$ United States Supreme Court. Abrams et. al v. United States. Op. cit.

${ }^{120}$ LEWIS, Anthony. Op. cit., p. 23
} 
guerra" ${ }^{121}$. No entanto, o juiz começa a mudar sua posição a respeito do direito à liberdade de expressão no caso Abrams, por considerar que um discurso que não criasse um perigo iminente, claro, e presente não poderia ser punido ${ }^{122}$.

O caso diz respeito a quatro refugiados russos que fugiram da tirania dos czar para os Estados Unidos. O grupo era contra os Estados Unidos enviarem tropas para a Rússia após a revolução bolchevique, e jogaram panfletos do topo de prédios em Nova Iorque pregando a realização de uma greve geral como protesto. A opinião majoritária da Suprema Corte determinou que o objetivo dos panfletos era destruir os planos de guerra dos Estados Unidos por meio da greve geral, e incitar descontentamento com o governo americano, tendo como finalidade última a realização de uma revolução. A Corte portanto confirmou as condenações ${ }^{123}$.

Sem afirmar que os casos anteriormente julgados pela Corte, e dos quais ele foi o relator, foram decisões erradas, Holmes irá afirmar que a Primeira Emenda garante que um discurso só poderá ser punido se se pode provar um "perigo claro e iminente" que tal expressão irá gerar um mau substancial que a Constituição americana autoriza que o Estado tente prevenir. Holmes então aplica o padrão ao caso concreto e conclui que claramente os panfletos no presente caso não teriam o poder de impedir o sucesso americano na Guerra. Pelo contrário, o magistrado afirma que os réus haviam sido condenados a vinte anos de prisão pela publicação de um panfleto que eles tinham tanto direito de publicar quanto o Governo tem de publicar a Constituição. E mesmo que seu razonamento jurídico estivesse

\footnotetext{
${ }^{121}$ Confore indica Anthony Lewis, a lei tornava crime "to utter, print, write or publish any disloyal, profane, scurrilous or abusive language" sobre a constituição, as forces armadas, uniformes militares ou a bandeira. LEWIS, Anthony. Op. cit., p. 25

${ }^{122}$ As razões por trás da mudança de Holmes sobre a importância do direito à liberdade de expressão não são claras. No entanto, Lewis e Feldman apontam para a crítica sofrida por Holmes pela comunidade jurídica quanto às decisões tomadas nos outros casos, especialmente pelo juiz federal Hand, que se correspondia com Holmes recorrentemente nesta época, e por um artigo publicado na época pelo Professor de Harvard Zecharia Chafee Jr sobre liberdade de expressão em tempos de guerra. Neste sentido, ver: LEWIS, Anthony. Op. cit., p. 29-30; FELDMAN, Stephen. Op. cit., localização 3710-3734.

${ }^{123}$ United States Supreme Court. Abrams et. al v. United States. Op. cit
} 
errado, afirma Holmes, a pena cominada aos réus foi absolutamente excessiva para o perigo que poderia ser gerado pelos panfletos, a não ser que o que estivesse de fato sendo punido fosse a crença e as opiniões dos réus, as quais de forma alguma deveriam ser levadas em consideração pelo tribunal ${ }^{124}$.

É a ideia da punição do discurso crítico por si mesmo, isto é, sem que gere um perigo iminente e real, que Holmes critica em seu voto dissidente. Retomando a ideia já desenvolvida por Milton e Mill de que a verdade será vitoriosa em um confronto de ideias, é Holmes quem finalmente cunha o termo do "mercado de ideias":

"Mas quando os homens tiverem percebido que o tempo [has upset many fighting faiths], eles podem vir a acreditar ainda mais do que eles acreditam nas fundações de suas próprias condutas que o bem último desejável é melhor alcançado pela livre troca de ideias - que o melhor teste da verdade é o poder do pensamento de fazer com que ele mesmo seja aceito em competição com o mercado, e que a verdade é a única base sobre que seus desejos podem ser atingidos com segurança. Esta, de qualquer forma, é a teoria da nossa Constituição ${ }^{125}$."

Neste sentido, Holmes argumenta que uma opinião não pode ser suprimida simplesmente por ser dissidente, odiosa, ou ofensiva, devendo a sociedade ser eternamente vigilante contra,

"tentativas de restringir a expressão de opiniões que odiamos e acreditamos serem periculosas a menos que elas ameacem interferir com os propósitos legítimos e urgentes da lei de forma tão iminente que uma restrição imediata é requerido para salvar o país ${ }^{126}$ ".

Holmes termina seu voto retornando ao debate travado mais de um século antes do caso em torno da Lei de Sedição, afirmando que a difamação sediciosa da common law não está vigente nos Estados Unidos, como a história demonstrou com a rejeição da lei de 1798, e com a restituição das multas cominada à época. A correção de opiniões "más" deve ser deixada para o tempo e a história, no mercado de ideias, com a exceção daquelas cujo perigo iminente não torna a correção pela história possível. Holmes conclui que os direitos à liberdade de expressão dos réus

\footnotetext{
${ }^{124}$ Idem.

${ }^{125}$ Idem.

${ }^{126}$ Idem.
} 
garantidos pela Constituição foram, portanto, violados. $\mathrm{O}$ magistrado Brandeis dissentiu junto com Holmes, concordando com seu voto ${ }^{127}$.

Ao longo da década seguinte, Holmes e Brandeis irão escrever votos dissidentes em diversos casos envolvendo o direito à liberdade de expressão, com a Suprema Corte sempre julgando contra a proteção de tal direito no caso concreto.

Em um voto concorrente no caso Whitney v. California, considerado por muitos como "a maior declaração judicial de argumentos em prol da liberdade de expressão ${ }^{128}$," Brandeis irá expandir a proteção à liberdade de expressão no que diz respeito a sua relação com a democracia republicana. O caso, decidido em 1927, diz respeito a Anita Whitney, que havia sido condenada por criar Partido Comunista da Califórnia, o qual supostamente advogada o "criminalismo sindical". Brandeis criticou a decisão da Suprema Corte por esta não estar de acordo com o teste do perigo presente e imediato: é necessário que a expressão fosse de fato uma incitação que tivesse grande probabilidade levasse à séria violência contra o Estado ${ }^{129}$.

Neste viés, Brandeis afirmou que os fundadores americanos buscaram um governo no qual a deliberação deveria prosperar contra a arbitrariedade, no qual a liberdade não fosse uma apenas uma finalidade, mas também um meio. Isto é: não se busca a supressão de determinadas ideias nocivas, mas sim a discussão sobre as mesmas, para alcançar a verdade política:

"Eles acreditavam que a liberdade de alguém pensar como queira e de falar como pensa são meios indispensáveis à descoberta e dispersão da verdade política; que sem liberdade de expressão e associação, discussão seria inútil; que com elas, a discussão provê proteção normalmente adequada contra a disseminação de doutrina nociva; que a maior ameaça à liberdade é um povo inerte; que discussão pública é um dever político; e que esta deve ser um princípio fundamental do governo americano ${ }^{130 \text {,. }}$

\footnotetext{
${ }^{127}$ Idem.

${ }^{128}$ LEWIS, Anthony. Op. cit., p. 35

${ }^{129}$ Supreme Court of the United States. Whitney v. California 274 U.S. 357 Rel. Justice Sanford, District of Columbia, 16 de maio de 1927.

${ }^{130}$ Idem.
} 
Segundo Brandeis, os fundadores sabiam que a garantia da ordem pública não seria alcançada pelo medo da punição de um crime, mas sim pela oportunidade de discussão sobre questões públicas e propostas para a correção de eventuais erros governamentais. A primeira emenda é a prova de que os fundadores acreditavam no "poder da razão aplicado por meio da discussão pública", esquivando-se assim do "silêncio coagido pela lei". A liberdade de expressão foi garantida pela Constituição, argumenta Brandeis, como uma proteção contra "ocasionais tiranias da maioria governante". Este argumento parece deixar implícita a noção de que a ratio por trás da Primeira Emenda é justamente a de proteger a expressão dissidente daquela adotada pelo governo representante das maiorias ${ }^{131}$.

Os fundadores americanos, argumenta Brandeis, não tinham medo da mudança política que poderia ser causada pela expressão dissidente, e não "exaltavam a ordem ao custo da liberdade". O processo do governo pelo povo, por meio da discussão racional, não poderia estar em perigo pelo discurso, a não ser que tal perigo fosse claro, iminente e atual a ponto de impedir a discussão sobre a questão. Neste ponto, Brandeis reafirma a ideia já desenvolvida por Holmes no caso Abrams, e alega que é o remédio para o discurso falso é o próprio discurso, e não a imposição do silêncio ${ }^{132}$.

Ao final, Brandeis concordou com o julgamento da Corte de não reverter a condenação de Whitney por uma questão jurisdicional ${ }^{133}$.

Apenas em 1931, e após uma década de votos dissidentes de Brandeis e Holmes, a Suprema Corte pela primeira vez decidiu um caso concordando com as alegações dos recorrentes pela liberdade de expressão. O caso Stromberg v. Califórnia, dizia respeito a uma lei do Estado da Califórnia que criminalizava o uso de bandeiras vermelhas ou símbolos que estimulassem a anarquia ou propaganda de natureza sediciosa. A Corte, em uma decisão de 7 votos a 2, decidiu pela reversão da condenação de Yetta Stromberg com base na lei, uma vez que, pela amplitude e vagueza da

\footnotetext{
${ }^{131}$ Idem.

132 Idem.

${ }^{133}$ Idem.
} 
mesma, esta poderia incluir a condenação de expressão dissidente e pacífica. Na mesma linha de Holmes e Brandeis, a Suprema Corte determina que a supressão da expressão apenas poderia ser feita quando estas incitassem a violência, apesar de não explicitar claramente a doutrina do perigo "iminente e claro". Não obstante, a decisão reafirma a importância da expressão dissidente do debate democrático, ao reconhecer como um princípio fundamental do sistema constitucional americano a "manutenção da discussão política livre", uma vez que "o governo deve responder à vontade do povo" 134 .

Com o fundamento em uma cultura agora não apenas política, mas também jurídica, protetora da expressão dissidente, e que seguirá se desenvolvendo pelas próximas três décadas, a Suprema Corte irá desenvolver seus mais importantes parâmetros relativos ao direito à crítica $\mathrm{e}$ ao discurso robusto sobre autoridades e questões públicas em 1964, no âmbito do caso New York Times v. Sullivan.

\section{1.b O caso New York Times Co. v. Sullivan}

O caso versa sobre um processo por difamação civil ajuizado por um comissionado de polícia, autoridade pública eleita da cidade de Montgomery, no Estado do Alabama, contra o jornal New York Times e outros réus pela publicação de uma publicidade de caráter político, a favor do movimento de direitos civis e da luta de Martin Luther King Jr. A publicidade fazia referência à supressão de protestos a favor do movimento de direitos civis para Afro-Americanos, e a diversas ocorrências onde a polícia teria buscado reprimir tais manifestações. O comissionado Sullivan processou o jornal alegando que alguns dos fatos publicados no anúncio eram falsos, e que o difamavam, uma vez que ele era o responsável por supervisionar o trabalho do departamento de polícia. O juízo de primeira instância condenou os réus ao pagamento de US\$500.000,00 (quinhentos

\footnotetext{
${ }^{134}$ Supreme Court of the United States. Stromberg v. California/283 U.S. 359 Rel. Justice Hughes, District of Columbia, 18 de maio de 1931. LEWIS, Anthony. Op. cit., p. 39-40
} 
mil dólares) pelos danos causados ao autor, o que foi mantido nas instâncias estatais superiores. Não foi necessária prova de dano uma vez que as cortes haviam considerado a publicação como difamatória per se, por tender a injuriar a reputação do autor com relação a sua profissão, ou por tender a colocá-lo sob disdém do público ${ }^{135}$.

Com relação aos fatos, é importante ressaltar que a Suprema Corte dos Estados Unidos constata já inicialmente que não há controvérsias que alguns dos fatos contidos no anúncio não descreviam com precisão os eventos que ocorreram em Montgomery, incluindo dentre estes a alegação de que a polícia nunca haveria cercado o campus, o número de vezes em que Martin Luther King foi preso, e a imputação de que a polícia teria fechado a porta do refeitório do campus com cadeados para manter protestantes fora do local ${ }^{136}$.

Conforme colocado por Magistrado Brennan no início de seu voto, a questão que deve ser determinada pela Suprema Corte neste caso é "a extensão a qual as proteções constitucionais da expressão e da imprensa limitam o poder de um estado de arbitrar danos numa ação de difamação proposta por um servidos público contra críticos da sua conduta enquanto servidor" ${ }^{137}$.

O juiz ressalta que o mero fato de uma expressão ser difamatória não lhe dá imunidade a uma análise para determinar se a restrição à liberdade de expressão está de acordo com o permitido pela Primeira Emenda.

Este caso será a primeira vez que a Corte se manifestará sobre o nível de proteção que deve ser acordado especificamente à expressão crítica de autoridades públicas. Neste sentido, são exatamente as bases filosóficas e políticas relativas à importância e papel da liberdade de expressão em uma sociedade democrática que irão ser utilizadas como o fundamento central da decisão escrita por Brennan no caso New York Times v. Sullivan. Por sua vez, são os votos de Holmes e Brandeis, em casos como Abrams e

\footnotetext{
${ }^{135}$ Supreme Court of the United States. New York Times Co. v. Sullivan. Op. cit.

${ }^{136}$ Idem.

${ }^{137}$ Idem.
} 
Whitney (citados no item anterior), que proverão à Suprema Corte o substrato jurídico para a conversão da linguagem político-filosófica em uma linguagem jurídico-legal.

Assim, Brennan inicialmente constata que a proteção pela Primeira Emenda da expressão sobre questões públicas já era uma tese consolidada pela jurisprudência constante do Tribunal, e que tal proteção constitucional é necessária para garantir a "livre troca de ideias para o alcance de mudanças políticas e sociais desejadas pelo povo". Segundo o magistrado, a sociedade americana preza a discussão aberta, vigorosa, e inclusive de mau gosto, sobre questões públicas, e - como havia sido formulado por Brandeis no caso Whitney - tal discussão pública é um dever público, cujo remédio deveria ser mais expressão, e não o silêncio. O caso concreto, portanto, deve ser analizado,

"contra o pano de fundo de um compromisso nacional profundo com o princípio que debate sobre assuntos públicos deve ser desimpedido, robusto, aberto, e que ele pode muito bem incluir ataques veementes, cáusticos, e por vezes desagradavelmente afiados contra o governo e seus representantes"138.

Neste viés, Brennan qualifica a expressão sob análise como uma expressão crítica relativa a uma das maiores questões atuais daquela época (no caso, o movimento pelos direitos civis), concluindo que esta estaria sujeita à maior proteção da Primeira Emenda. Uma primeira questão central é então colocada: a mera constatação de que a expressão proferida no caso concreto contém elementos factuais falsos é suficiente para afastar tal proteção especial?

Em resposta, o juiz constata que interpretações diversas das garantias da primeira emenda consistentemente afastaram a ideia de um "teste de verdade" sobre a expressão proferida, seja este realizado por um juiz ou um júri, e especialmente um teste que coloque o ônus da prova naquele que proferiu a expressão. Neste sentido, a proteção constitucional não depende da veracidade, da popularidade, ou da utilidade social da expressão. Brennan então retoma a doutrina de Madison a respeito da liberdade de 
expressão, constatando que, no contexto da liberdade de imprensa, um grau de abuso é inseparável de seu uso apropriado. Sobre este ponto específico, Brennan cita ainda John Stuart Mill, quando o autor sugere, em sua obra $A$ Liberdade, que a lei não deve suprimir expressões falsas feitas de boa-fé. Assim, o juiz conclui que a falsidade é inevitável em um debate livre, devendo esta também ser protegida para garantir o "breathing space" necessário para a sobrevivência da liberdade de expressão ${ }^{139}$.

Brennan então introduz uma segunda questão central: a injúria à reputação de uma autoridade pública autorizaria a repressão da expressão crítica? Para responder à pergunta, o juiz retoma a jurisprudência da Suprema Corte em casos envolvendo a dignidade e reputação de juízes, constatando que a reputação de cortes não justificam a punição de desacato criminal por críticas feitas ao juiz ou à decisão, mesmo quando estas estão eivadas de fatos errôneos. Brennan conclui que a diminuição da reputação oficial de uma autoridade pública como resultado de uma crítica efetiva não faz com que tal expressão perca sua proteção constitucional ${ }^{140}$.

Constatando que nem a falsidade e nem o conteúdo difamatório (ou seja, que diminui a reputação de uma autoridade pública) são suficientes para afastar a proteção constitucional, o magistrado determina uma combinação dos dois elementos para a repressão do discurso não seria adequada para a proteção da reputação de uma autoridade pública. É neste contexto que Brennan passa a analizar, quase duzentos anos após sua aprovação, a Lei de Sedição de 1798, a qual, segundo o magistrado, “cristalizou pela primeira vez uma percepção nacional do significado central da Primeira Emenda" ${ }^{141}$.

Relembrando que o ato de 1798 aceitava a verdade como defesa, Brennan aponta que, não obstante, a lei foi extremamente criticada como inconstitucional por pessoas como James Madison, por ir de encontro à forma de governo adotada pelos Estados Unidos: um governo onde o povo,

\footnotetext{
${ }^{139}$ Idem.

${ }^{140}$ Idem.

${ }^{141}$ Idem.
} 
e não o Estado, tem a soberania; e onde, consequentemente há um direito à crítica livre de pessoas e medidas públicas (como determina a "premissa de Madison"). A lei, apesar de nunca ter sido analisada diretamente pela Suprema Corte, teria sido, portanto, sido invalidada pelo "tribunal da história", com os perdões concedidos por Jefferson e a restituição das multas aplicadas subsequentemente aprovadas pelo Congresso Nacional. Neste sentido, Brennan referencia também o voto do magistrado Holmes no caso Abrams, no qual o juiz se manifestou contra a Lei de Difamação Sediciosa. Assim, o relator conclui que existe um consenso de que a lei, "por conta da restrição que impunha à crítica ao governo e à autoridades públicas, era inconsistente com a Primeira Emenda" ${ }^{142}$.

Assim como a Lei de Sedição, Brennan constata que a difamação civil imposta no caso New York Times v. Sullivan tem o poder de inibir o debate sobre questões públicas e causar medo e intimidação em jornais que dão voz à crítica a autoridades públicas. Neste sentido, a possibilidade da utilização da verdade como defesa não é suficiente para a garantia do direito à liberdade de expressão, pois tal regra exige que todos aqueles que propaguem expressão crítica da conduta de autoridades públicas tenham a capacidade de provar a verdade sobre suas afirmações para a satisfação de um tribunal, sob pena de sanções legais, gerando a "autocensura". Assim, Brennan aponta, tal exigência não significa que apenas o discurso falso será restringido ${ }^{143}$, uma vez que a prova legal de que uma afirmação é verdadeira em todos os seus aspectos é difícil de ser alcançada. Deste modo, críticos de autoridades públicas deixariam de fazer aquelas alegações que, mesmo acreditando verdadeiras, não têm a certeza de que poderiam ser provadas em um tribunal ${ }^{144}$.

Com base nas constatações acima, Brennan conclui que a regra que coloca o ônus da prova da verdade no réu restringe o vigor e a variedade do

\footnotetext{
${ }^{142}$ Idem.

${ }^{143}$ Ainda assim, Brennan aponta, citando John Stuart Mill e John Milton, que mesmo o discurso falso pode contribuir ao debate público, na medida em que dá clara percepção da verdade em contraste a esta.

${ }^{144}$ Idem.
} 
debate público, e é inconsistente com a Primeira Emenda. O juiz então define o parâmetro adequado para a proteção da expressão crítica de autoridades públicas requer que o autor supostamente ofendido prove que a expressão foi realizada com "real malícia", isto é, "com o conhecimento de que era falsa ou com manifesta negligência sobe se era falsa ou não" ${ }^{145}$.

Ao justificar esta proteção especial, Brennan afirma que a prova da "real malícia" é também o parâmetro já utilizado para proteger a expressão proferida por autoridades públicas no exercício de suas funções, parâmetro este necessário para garantir que o discurso de figuras públicas seja vigoroso e sem inibição para a efetiva realização de políticas públicas. Uma proteção análoga, portanto, deve ser outorgada aos cidadãos críticos do governo, uma vez que "é tanto seu dever criticar como o é dever do servidor público administrar". Citando as ideias de Madison sobre a soberania do povo e seu poder de crítica ao governo, Brennan conclui que é necessário outorgar uma imunidade ao discurso crítico a autoridades públicas análoga àquela já outorgada à expressão proferida por autoridades públicas, sob pena de garantir a servidores públicos uma preferência injustificada sobre o povo que servem ${ }^{146}$.

Considerando finalmente o caso concreto, o relator conclui que não foi provada a real malícia dos réus na publicação realizada, e que os autos demonstravam uma mera negligência destes ao checar a veracidade dos fatos publicados, o que não consitituía o nível de negligência requerido pelo parâmetro da real malícia. Ainda, Brennan aponta que o caso foi agravado pela crítica no caso ter sido dirigida a uma instituição governamental (no caso, a polícia), e não diretamente ao autor da ação (o comissário Sullivan).

Assim, em uma decisão de 9 votos a 0, a Suprema Corte declarou que a lei do Estado do Alabama como aplicada no caso concreto falhou em outorgar as proteções necessárias para a liberdade de expressão requeridas 
pela Constituição americana em casos de difamação ajuizados por autoridades públicas contra críticas à sua conduta pública ${ }^{147}$.

É importante ressaltar ainda que, não obstante a decisão ter sido unânime, os magistrados Black e Golberg redigiram votos concorrentes onde argumentaram que mesmo o parâmetro da real malícia não seria suficiente para a proteção adequada do direito à liberdade de expressão crítica a autoridades públicas, argumentando por pela imunidade absoluta da expressão crítica, como um "privilégio incondicional". Golberg e Black fundamentaram seus votos especialmente na importância da crítica à autoridades públicas em uma sociedade democrática, e do controle social a ser exercido pelo povo soberano quanto a seus governantes, citando para tal fontes como o julgamento de Peter Zenger e a Lei de Sedição de 1798. Para os dois juízes, a crítica livre a autoridades públicas é um princípio e pressuposto da sociedade americana, não podendo esta ser livre se há qualquer possibilidade de sanção financeira ou física a quem critique o governo. Assim, conclui Black, "um direito incondicional de um dizer o que pensa sobre assuntos públicos é a garantia mínima da Primeira Emenda" ${ }^{148}$.

\section{1.c Após New York Times v. Sullivan}

No mesmo ano de julgamento do caso paradigmático New York Times v. Sullivan, a Suprema Corte ampliou a aplicação da doutrina da real malícia para casos envolvendo a difamação no âmbito criminal. Assim, no caso Garrison v. Lousiana, também decidido por nove votos a zero, a Suprema Corte declarou inconstitucional a lei de difamação criminal do Estado de Lousiana, por esta não exigir, em casos de crítica à conduta oficial, a prova pela acusação da real malícia, ou seja, de que o réu sabia

\footnotetext{
${ }^{147}$ Idem.

${ }^{148}$ Idem.
} 
que expressão proferida era falsa ou foi manifestamente negligente em averiguar sua falsidade ${ }^{149}$.

No caso concreto, a lei de Lousiana tornava mais difícil a punição da crítica à conduta oficial, demandando a prova de que esta tivesse sido realizada sem a "crença razoável de que era verdadeira", ou com "má fé" (ill-will). Não obstante, a Suprema Courte determinou que estas garantias não eram suficientes tendo em vista os parâmetros definidos em New York Times v. Sullivan; isto é, não eram análogas à doutrina da real malícia, a qual também deveria ser aplicada a casos envolvendo a difamação criminal, afastando a argumentação de que leis criminais e sanções civis por difamação serviriam objetivos distintos ${ }^{150}$.

Em sua decisão, a Suprema Corte apontou que, enquanto a ratio original da difamação criminal seria a de impedir a quebra da paz pela vítima das ofensas (o que consequentemente criminalizava também a difamação sobre fatos que fossem verdade), tal ratio não mais poderia ser aplicada na sociedade contemporânea, quando o direito é considerado pela sociedade como a forma apropriada para a solução de conflitos, e não mais a força física. Não obstante, ressalta a decisão, mesmo em sociedades onde a violência privada era aceita, o litígio civil por difamações era utilizado na prática de maneira preferencial à via penal em casos que não se relacionavam a assuntos públicos. Assim, o direito penal era utilizado primariamente apenas por meio do crime de difamação sediciosa, isto é, da expressão proferida contra o governo e suas autoridades ${ }^{151}$.

No entanto, e com base na doutrina desenvolvida pelo caso $\mathrm{New}$ York Times $v$. Sullivan, a Corte ressalta que, numa sociedade democrática, o debate sobre questões públicas é um direito fundamental, assim como essência do "auto-governo", devendo ser aberto, robusto, e protegido pela aplicação da doutrina da real malícia. A lei de Louisiana, determina a Corte,

\footnotetext{
${ }^{149}$ Supreme Court of the United States. Garrison v. Lousiana/379 U.S. 64 Rel. Justice Brennan, District of Columbia, 23 de novembro de 1964.

${ }^{150}$ Idem.

${ }^{151}$ Idem.
} 
previa a necessidade da prova de "malícia", mas a definia meramente como a "intenção de causar dano", e não como a intenção de "causar dano por meio da propagação de um fato falso", como requer a doutrina da real malícia, a qual deve ser aplicada tanto em casos de sanções civis como penais. Black e Golberg, novamente escrevendo votos concorrentes, se pronunciaram a favor da absoluta liberdade para criticar autoridades públicas, adicionando ainda que, como já havia afirmado Holmes quase meio século antes, a resposta à Lei de Sedição de 1798 deixou claro que não existia lugar no direito americano para a punição pelo crime de difamação sediciosa, não podendo os Estados editarem leis com esse fim, as quais eram uma relíquia do Star Chamber autoritário britânico, que buscava a proteção da monarquia $^{152}$.

Como um último ponto sobre a jurisprudência da Suprema Corte americana a respeito da crítica realizada contra pessoas ou autoridades públicas, é importante ressaltar a decisão do Tribunal no caso Hustler Megazine v. Folwell (1988), quando a Corte determinou que um processo por difamação só pode ocorrer com relação a expressões que possam ser entendidas como possuindo um caráter factual. É dizer: opiniões, por mais ofensivas e hiberbólicas que sejam, não podem ser sancionadas se não constituírem fatos falsos, quando deverá ser ainda aplicada a doutrina da real malícia. Assim, leis que criminalizam ou proíbem "insultos” ou ofensas com base em opiniões subjetivas, estariam proscritas pela Constituição estadounidense ${ }^{153}$.

Deste modo, nos Estados Unidos, a expressão crítica de figuras ou autoridades públicas só pode ser criminalizada caso a expressão verse sobre fatos falsos, e tenha sido realizada com real malícia. Atualmente, não há qualquer lei que criminalize a difamação no nível federal. No nível estadual, apenas 16 dos 50 Estados americanos ainda definem a difamação

\footnotetext{
152 Idem.

${ }^{153}$ Supreme Court of the United States. Hustler Megazine v. Falwell/485 U.S. 46 Rel. Justice Rehnquist, District of Columbia, 24 de fevereiro de 1988.
} 
como um crime ${ }^{154}$. Um estudo realizado no ano de 2005 demonstrou ainda que, de 1992 a 2004, apenas 41 ações por difamação criminal foram tentadas no país, sendo apenas seis pessoas condenadas. Dentre estas, três condenações foram revertidas após apelações, que afastaram a aplicação das lei penais estatais por estas serem inconstitucionais ${ }^{155}$.

Os parâmetros determinados pela Suprema Corte no paradigmático caso New York Times v. Sullivan tiveram grande influência não apenas na cultura e na sociedade estadounidense, mas também na doutrina desenvolvida por órgãos internacionais de direitos humanos quanto ao direito à liberdade da expressão crítica de autoridades públicas. Especialmente dentre estes, os órgãos do Sistema Interamericano de Direitos Humanos terão um papel essencial no desenvolvimento dos padrões de proteção da expressão crítica, particularmente no que tange a figura dos delitos de "desacato" e dos chamados "crimes contra a honra", prevalentes no direito latino americano.

\section{O Sistema Interamericano de Direitos Humanos e as} "leis de desacato"

\section{2.a Considerações gerais}

Desde o início do retorno à democracia após as ditaduras do Cone Sul e as guerras civis da América Central, o Sistema Interamericano de Direitos Humanos da Organização dos Estados Americanos (OEA) passa a assumir um papel essencial na transição para e consolidação de sistemas democráticos no continente americano. Nesta função, ambos os órgãos

\footnotetext{
${ }^{154}$ Organization for Security and Co-operation in Europe. Liber and Insult Laws: A Matrix on Where We Stand and What We Would Like to Achieve. Vienna, 2005. Disponível em: $<$ http://www.osce.org/fom/41958>. Acesso em 8 de novembro de 2012. O estudo aponta que, em 2005, 17 eram os Estados americanos que criminalizavam a difamação (Lousiana, Florida, Idaho, Colorado, Kansas, Michigan, Minnesota, Montana, New Hampshire, New Mexico, North Carolina, North Dakota, Oklahoma, Utah, Virginia, Washington, e Wisconsin). Desde então, em 2012, o Estado do Colorado descriminalizou a difamação criminal. Neste sentido, ver: IPI/IFEX. Colorado Repeals Criminal Libel Law. 20 de abril de 2012. Disponível em: $<$ http://www.ifex.org/united states/2012/04/20/colorado repeal/>. Acesso em 8 de novembro de 2012.

${ }^{155}$ Organization for Security and Co-operation in Europe. Liber and Insult Laws: A Matrix on Where We Stand and What We Would Like to Achieve. Op. cit.
} 
deste sistema regional de proteção dos direitos humanos - a Comissão e a Corte Interamericanas - passam a outorgar em sua jurisprudência uma importância fundamental ao direito à liberdade de expressão, buscando a eliminação de instrumentos frequentemente utilizados pelos governos autoritários que até então controlavam os Estados americanos, como a censura prévia e as chamadas "leis de desacato""156.

O próprio marco jurídico interamericano demonstra o alto nível de proteção outorgado ao direito à liberdade de expressão pelos Estados da OEA. A Convenção Americana sobre Direitos Humanos $(\mathrm{CADH})^{157}$, adotada em 1969, é considerada pela Corte Interamericana como o tratado internacional de direitos humanos que mais outorga garantias a esta liberdade, ao tornar as hipóteses legais para sua restrição limitadas apenas a responsabilidade ulterior em casos de sua necessidade para a proteção dos direitos e reputações das demais pessoas, ou para a proteção da segurança nacional, ordem pública, saúde ou moral públicas ${ }^{158}$. Sendo assim, e ao contrário de outros tratados de proteção de direitos humanos -- como a Convenção Européia de Direitos Humanos e o Pacto Internacional de

\footnotetext{
156 Neste sentido, ver: ABRAMOVICH, Victor. De las violaciones masivas a los patrones estructurales: nuevos enfoques y clásicas tensiones en el Sistema Interamericano de Derechos Humanos. Sur: revista internacional de derechos humanos da Red Universitaria de Derechos Humanos. V. 6, No. 11, dezembro, 2009; Relatoria para a Liberdade de Expressão da Comissão Interamericana de Direitos Humanos. Una agenda hemisferica para la defensa de la libertad de expresión. OEA/Ser.L/V/II CIDH/RELE/INF. 4/09, 25 de fevereiro de 2009.

${ }^{157}$ O artigo 13 da Convenção Americana sobre Direitos Humanos prevê: "Liberdade de pensamento e de expressão: 1. Toda pessoa tem o direito à liberdade de pensamento e de expressão. Esse direito inclui a liberdade de procurar, receber e difundir informações e ideias de qualquer natureza, sem considerações de fronteiras, verbalmente ou por escrito, ou em forma impressa ou artística, ou por qualquer meio de sua escolha. 2. O exercício do direito previsto no inciso precedente não pode estar sujeito à censura prévia, mas a responsabilidades ulterior, que devem ser expressamente previstas em lei e que se façam necessárias para assegurar: a) o respeito dos direitos e da reputação das demais pessoas; b) a proteção da segurança nacional, da ordem pública, ou da saúde ou da moral públicas. 3. Não se pode restringir o direito de expressão por vias e meios indiretos, tais como o abuso de controles oficiais ou particulares de papel de imprensa, de frequências radioelétricas ou de equipamentos e aparelhos usados na difusão de informação, nem por quaisquer outros meios destinados a obstar a comunicação e a circulação de ideias e opiniões. 4. A lei pode submeter os espetáculos públicos a censura prévia, com o objetivo exclusivo de regular o acesso a eles, para proteção moral da infância e da adolescência, sem prejuízo do disposto no inciso 2. 5. A lei deve proibir toda propaganda a favor da guerra, bem como toda apologia ao ódio nacional, racial ou religioso que constitua incitamento à discriminação, à hostilidade, ao crime ou à violência."

${ }^{158}$ Corte IDH. Opinião Consultiva No. 5/85 de 13 de novembro de 1985. Série A No. 5., pars. 50 e 
Direitos Civis e Políticos -- a CADH proíbe expressamente a censura prévia, inclusive quando se trata dos chamados "discursos de ódio", ou de expressões ofensivas. Neste sentido, os únicos tipos de expressões considerados pelos órgãos do sistema como "discursos não protegidos" per se - isto é, discursos que não fazem parte do direito à liberdade de expressão - são a pornografia infantil, a incitação ao genocídio, e a incitação à violência ${ }^{159}$.

A ligação intríseca entre o direito à liberdade de expressão e a democracia é constantemente reconhecida e ressaltada na jurisprudência de ambos os órgãos do sistema interamericano, assim como nas resoluções e documentos adotados pelos Estados americanos ${ }^{160}$. Neste viés, buscando uma ainda maior proteção do direito à liberdade de expressão no momento crucial de transições democráticas, em 1997 é criada pela Comissão Interamericana a Relatoria Especial para a Liberdade de Expressão, com a missão de "promover a consciência pelo pleno respeito ao direito à liberdade de expressão e informação no hemisfério, em consideração ao papel fundamental que este direito tem no fortalecimento e desenvolvimento do sistema democrático e na denúncia e proteção dos demais direitos" ${ }^{161}$. Até hoje, esta Relatoria é a única existente no âmbito da Comissão Interamericana com um Relator Especial e independência funcionais, e a produção de seus relatórios temáticos e anuais, aprovados pela CIDH, são a principal fonte de interpretação da amplitude do direito à liberdade de expressão nos instrumentos do Sistema Interamericano. Além da criação da Relatoria, a adoção de instrumentos como a Carta Democrática Interamericana e a Declaração de Princípios sobre Liberdade de Expressão demonstram o reconhecimento do alto nível de proteção

\footnotetext{
${ }^{159}$ Relatoria para a Liberdade de Expressão da Comissão Interamericana de Direitos Humanos. Marco jurídico interamericano sobre el derecho a la libertad de expresión. OEA/Ser.L/V/II CIDH/RELE/INF. 2/09. 30 de dezembro de 2009, pars. 57-60.

${ }^{160}$ Idem, par. 8.

161 CIDH. Relatoria para la libertad de expresión. Disponível em: $<$ http://www.oas.org/es/cidh/expresion/index.asp $>$. Acesso em 8 de novembro de 2012. CIDH. Mandato de la Relatoría Especial para la Libertad de Expresión. Disponível em: $<$ http://www.oas.org/es/cidh/expresion/mandato/default.asp >. Acesso em 8 de novembro de 2012.
} 
outorgado a este direito, e do caráter da liberdade de expressão como pedra de toque para a proteção de regimes democráticos ${ }^{162}$.

O marco jurídico interamericano prevê uma função tripla ao direito à liberdade de expressão no sistema democrático: primeiro, como o direito fundamental que possibilita a orientação do pensamento individual e o compartilhamento de tal pensamento; segundo, como um dos direitos que possuem uma relação estrutural com a democracia, sendo essencial para a consolidação de uma sociedade verdadeiramente democrária, tornando possível a deliberação pública, plural e aberta sobre assuntos concernentes ao interesse geral; e finalmente, como uma ferramenta para o exercício dos demais direitos humanos ${ }^{163}$.

A primeira decisão da Corte Interamericana sobre o tema se deu em 1985, com a emissão de uma opinião consultiva sobre a obrigatoriedade do diploma de jornalista ${ }^{164}$. A importância de tal decisão, no entanto, foi alem do debate acerca da questão concreta, uma vez que nesta o Tribunal assentou as bases gerais a respeito das obrigações dos Estados no que diz respeito à proteção do direito à liberdade de expressão, e explicitou quais os requisitos determinados pela Convenção Americana para a restrição legítima de tal direito.

Neste sentido, a Corte determinou que a liberdade de expressão só pode ser restrigida pela aplicação de responsabilidades ulterior ao discurso, e apenas nos casos de necessidade para a proteção dos direitos e reputações das demais pessoas, ou para a proteção da segurança nacional, ordem pública, saúde ou moral públicas. Nestas situações, para que a restrição seja legítima, e consequentemente esteja de acordo com o artigo 13.2 da CADH, é preciso que a restrição atenda a quatro requisitos: 1) a existência de

162 Organização dos Estados Americanos. Carta Democrática Interamericana. Aprovada na primeira sessão plenária, realizada em 11 de setembro de 2011, art. 4; CIDH. Declaração de Principios sobre Liberdade de Expressão. Disponível em: $<$ http://www.oas.org/es/cidh/expresion/showarticle.asp?artID=132\&lID=2>. Acesso em 8 de novembro de 2012.

${ }^{163}$ Relatoria para a Liberdade de Expressão da Comissão Interamericana de Direitos Humanos. Marco jurídico interamericano sobre el derecho a la libertad de expresión. Op. cit. pars. 6-10

${ }^{164}$ Corte IDH. Opinião Consultiva No. 5/85, Op. cit. 
sanções previamente estabelecidas; 2) a definição em lei de maneira expressa e taxativa da conduta sancionada; 3) a legitimidade dos fins perseguidos; 4) que tais sanções sejam necessárias para alcançar os fins buscados ${ }^{165}$.

A Corte frisa que, para a interpretação do direito à liberdade de expressão conforme determinado na Convenção, é preciso ter como base o objeto e fim do tratado, de modo que, ao se determinar se uma sanção à expressão está de acordo com a $\mathrm{CADH}$, esta deve necessariamente "vincular-se com as necessidades legítimas das sociedades e instituições democráticas" ${ }^{166}$, e com as justas exigências da democracia, especialmente considerando o papel da liberdade de expressão com a preservação e funcionamento de tais instituições. Neste ponto, a Corte determinou qualquer restrição deve estar voltada à satisfação de um "interesse público imperativo" 167 , devendo ser escolhida dentre as restrições aquela que em menor escala restriga o discurso, não sendo suficiente que a sanção sirva um propósito útil ou oportuno. Assim, as restrições devem "justificar-se segundo objetivos coletivos que, por sua importância, preponderam claramente sobre a necessidade social do pleno gozo d[a liberdade de expressão], não a limitando mais do que o estritamente necessário"168, devendo portanto tal restrição ser proporcional e estritamente ligada ao alcance do objetivo legítimo que a justifica. Ainda com relação às restrições, o Tribunal acrescenta que estas não podem constituir um meio indireto de impedir a comunicação e circulação de ideias ${ }^{169}$.

Utilizando portanto a sociedade e as instituições democráticas como pontos norteadores de interpretação, a Corte IDH determina que não se pode utilizar de conceitos como a "ordem pública" para justificar a restrição total de um direito como a liberdade de expressão, uma vez que, esta "se insere na ordem pública primária e radical da democracia, que não é

\footnotetext{
${ }^{165}$ Ibid. pars. 38-39

${ }^{166}$ Ibid. pars. 42

${ }^{167}$ Ibid. pars. 46

${ }^{168}$ Ibid. pars. 46

${ }^{169}$ Ibid. pars. 47
} 
concebível sem o debate livre e sem que a dissidência tenha direito a se manifestar" ${ }^{\prime 10}$. Neste viés, a Corte conclui:

"La libertad de expresión es una piedra angular en la existencia misma de una sociedad democrática. Es indispensable para la formación de la opinión pública. Es también conditio sine qua non para que los partidos políticos, los sindicatos, las sociedades científicas y culturales y, en general, quienes deseen influir sobre la colectividad puedan desarrollarse plenamente. Es, en fin, condición para que la comunidad, a la hora de jercer sus opciones, esté suficientemente informada. Por ende, es posible afirmar que una sociedade que no está bien informada no es plenamente libre. ${ }^{171 ",}$

Apesar da decisão da Corte Interamericana na Opinião Consultiva No. 5 não ter tratado diretamente do tema desta monografia - o direito à crítica ao governo em uma sociedade democrática - a decisão proferida naquela ocasião marca as principais bases para a delimitação do alcance do direito à liberdade de expressão no âmbito do Sitema Interamericano, sendo reiteramente utilizada por seus órgãos como fundamentação de suas decisões e relatórios. Neste sentido, a opinião consultiva No. 5 configura a principal base teórica na qual irá se apoiar a Comissão Interamericana para fundamentar seu mais importante relatório no que quiz respeito às "leis de desacato" dos regimes autoritários da América Latina e seu efeito no discurso crítico de instituições governamentais e suas autoridades.

\section{2.b O Relatório de 1994 da Comissão Interamericana de Direitos Humanos}

Em 1994, a Comissão Interamericana de Direitos Humanos dedicou um capítulo inteiro de seu Relatório Anual ao fenômeno das "leis de desacato" no hemisfério americano, considerando que ao menos quatorze países ainda criminalizavam este tipo de discurso. Na concepção da Comissão as "leis de desacato" são o tipo de legislação que penaliza especificamente "a expressão que ofende, insulta, ou ameaça um funcionário público no desempenho de suas funções oficiais" ${ }^{" 172}$.

\footnotetext{
${ }^{170}$ Ibid. pars. 69

${ }^{171}$ Ibid. pars. 70

${ }^{172}$ CIDH. Informe Anual de 1994. Capítulo V: Informe sobre la compatibilidade entre las leyes de desacato y la Convención Americana sobre Derechos Humanos. Disponível em: <http://www.cidh.org/annualrep/94span/cap.V.htm>. Acesso em 8 de novembro de 2012.
} 
A pergunta que a $\mathrm{CIDH}$ se coloca neste relatório é a seguinte: a criminalização da expressão porque ela está especialmente dirigida a funcionários públicos, e quando não há um perigo de violencia iminente, é compatível com o direito à liberdade de expressão garantido na Convenção Americana?

Para responder tal pergunta, a Comissão irá procurar determinar se as "leis de desacato" estão de acordo com os requisitos impostos pela Convenção Americana para a restrição da liberdade de expressão por meio de responsabilidades ulterior, previstos no artigo 13.2 do tratado, o qual, como já havia sido determinado pela Corte Interamericana, prevê quatro requisitos para a imposição de tais sanções: 1) que os fundamentos para estabelecer a sanção tenham sido determinados previamente; 2) que estejam previstos com precisão em uma lei; 3) que tenham uma finalidade legítima; 4) que sejam necessários para alcançar tal finalidade legítima. ${ }^{173}$.

Antes de iniciar a análise específica dos quatro requisitos, a $\mathrm{CIDH}$ aponta como os princípios retores da interpretação da Convenção Americana as "necessidades legítimas das sociedades e instituições democráticas", assim como a relação intríseca entre a liberdade de expressão e a democracia, retomando assim o entendimento da Corte Interamericana na opinião consultiva $5^{174}$. Neste ponto, a CIDH acrescenta que é a própria livre discussão sobre assuntos públicos que irá preparar uma sociedade para as tensões e fricções existentes, e impedir a paralização das ideias, concluindo que "uma sociedade livre, hoje e amanhã, é que aquela que pode manter abertamente um dialogo rigoroso sobre si mesma" ${ }^{175}$.

Passando para a análise específica sobre dois primeiros os requisitos previstos pela CADH para a restrição da liberdade de expressão pelo meio de responsabilidade ulterior, a Comissão considerou que a restrição com base no crime de desacato cumpria com o determinado pela Convenção, por estar estabelecido previamente em uma norma, sem realizar maiores 
considerações. Sendo assim, é apenas na análise do terceiro e do quarto requisito que a $\mathrm{CIDH}$ irá fazer considerações mais profundas sobre compatibilidade deste tipo de lei com a CADH ${ }^{176}$.

A Comissão então passa a determinar se as "leis de desacato" possuem uma finalidade legítima em uma sociedade democrática, analisando os fundamentos sob os quais estes tipos de crimes se sustentam. Neste sentido, segundo a CIDH, tais leis possuem como justificativa a necessidade de proteção da honra de funcionários públicos no que se refere à obrigação de manutenção da ordem pública, assim como a proteção do funcionamento adequado da administração pública. Assim, as "leis de desacato" cumpririam uma uma dupla função: protegem os funcionários públicos contra a expressão ofensiva ou crítica para que possam desempenhar duas funções sem obstáculos, garantindo o funcionamento armonico do governo; e protegem a ordem pública, uma vez que a crítica aos funcionários públicos teria um efeito desestabilizante para o governo nacional, pois a crítica refletiria não apenas no indivíduo criticado, mas também em seu cargo e na administração. É por este motivo que, como identifica a CIDH, as "leis de desacato" existentes no hemisfério no geral apenas protegem funcionários públicos enquanto no desempenho de suas funções oficiais ${ }^{177}$.

Neste sentido, as leis de desacato outorgam a funcionários públicos uma proteção da qual os demais membros da sociedade não dispõem. No entanto, como observa a Comissão, tal proteção especial "inverte diretamente o princípio fundamental de um sistema democrático que faz do governo objeto de controles, entre estes, o escrutínio da cidadania, para prevenir ou controlar o abuso de seu poder coativo". Tal inversão fica ainda mais clara se se considera que a proteção especial é outorgada ao funcionário público por ele estar efetivamente representando o governo, ocasião na qual, contrariamente, o direito à crítica por cidadãos da conduta 
de tais funcionários públicos é ainda mais essencial para uma sociedade democrática ${ }^{178}$.

Deste modo, a CIDH constata que o direito à liberdade de expressão tem como caráter fundamental o direito de participação em debates "firmes, ativos, e desafiantes" sobre o funcionamento da sociedade, de maneira que o tipo debate político garantido pela liberdade de expressão inevitavelmente gerará discursos críticos e até mesmo ofensivos a funcionários públicos no exercício de suas funções. A Comissão conclui que a proteção especial contra este tipo de discurso crítico outorgada pelas "leis de desacato" afeta a essência do direito à liberdade de expressão. Neste sentido, a Comissão cita ainda John Stuart Mill, e a necessidade da maior tolerância de ideias diversas para o alcance da verdade ${ }^{179}$.

Segundo a Comissão, as "leis de desacato" não configuram apenas uma restrição direta ao direito à liberdade de expressão, mas podem gerar também uma restrição indireta pela ameaça da aplicação das penas privativas de liberdade e de multa previstas em leis desta natureza, gerando uma auto-censura nos cidadãos, que deixam de expressar, por medo, suas críticas sobre questões públicas ${ }^{180}$.

Neste ponto, a CIDH observa ainda que a possibilidade de previsão legal do réu provar a veracidade da expressão proferida como defesa (a chamada "exceção da verdade") não é suficiente para evitar tal censura indireta, uma vez que o ônus da prova é colocado no acusado, e que grande parte das expressões críticas tem como base juízos de valor, e não de fato, sendo impossível sua prova. Tal tipo de exceção tornaria possível, portanto, a sanção de alguém que de boa-fé criticasse a administração pública, pelo mero fato da pessoa não ter a capacidade de provar a veracidade de suas afirmações perante um Tribunal. Assim, as "leis de desacato" são 
estabelecidas em uma estrutura que acaba por "proteger o próprio governo contra críticas" ${ }^{181}$.

Com base nas considerações anteriores, a Comissão conclui que as "leis de desacato" não possuem uma finalidade legítima em uma sociedade democrática, por suas justificativas serem contraditórias com o "princípio de que uma democracia devidamente funcional é certamente a maior garantia da ordem pública". Pelo contrario, tais leis buscam a proteção da ordem pública por meio da restrição ao direito à liberdade de expressão, o qual, por sua vez, é essencial para o devido exercício da democracia, afetando o debate aberto e rigoroso sobre questões públicas. Sendo assim, tais leis não cumprem com o terceiro requisito estabelecido pela Convenção Americana $^{182}$.

A Comissão faz ainda breves considerações quanto ao quarto requisito, isto é, a necessidade de tal restrição em uma sociedade democrática. Neste tema, a CIDH aponta que para que uma restrição seja necessária, é preciso demonstrar que a finalidade legítima que se busca alcançar com tal restrição não poderia ser alcançada de uma maneira menos restritiva da liberdade de expressão. A restrição ademais deve ser proporcional, atendendo a uma "necessidade social imperiosa", sem que se desnaturalize ou se prive de conteúdo real a liberdade de expressão ${ }^{183}$.

Segundo a Comissão, as "leis de desacato" não também cumprem tal requisito, uma vez que a proteção especial da expressão crítica de funcionários públicos no exercício de suas funções não é compatível com o objetivo de uma sociedade democrática de fomento ao debate público. Assim mesmo, tal proteção não é necessária pela existência de meios menos restritivos para a proteção da honra de funcionários públicos, os quais tem maior acesso à imprensa para responder a tais críticas, além da possibilidade de utilização de ações de caráter cível, e não criminal. As "leis de desacato" desnecessariamente limitam a expressão dirigida

\footnotetext{
${ }^{181}$ Idem

${ }^{182}$ Idem.

${ }^{183}$ Idem.
} 
especialmente contra funcionários públicos, os quais já estariam protegidas pelas leis que podem ser utilizadas por qualquer pessoa para a proteção de sua honra ${ }^{184}$.

A Comissão ainda frisa que, em uma sociedade democrária, funcionários públicos devem estar mais - e não menos - expostas à crítica e ao escrutínio dos cidadãos, pela necessidade de um debate aberto sobre questões públicas, que deve envolver a discussão sobre aqueles que participam na formulação e aplicação de políticas públicas, e que voluntariamente se expõe a tal escrutínio público, devendo portanto ser mais tolerantes à crítica. Assim, a proteção especial trazida pelas "leis de desacato" contra a expressão crítica de funcionários públicos no exercício de suas funções não é necessária em uma sociedade democrática, não estando de acordo com o artigo 13 da Convenção Americana ${ }^{185}$.

A Comissão conclui seu relatório constatando que o poder coercitivo trazido pelas "leis de desacato" restringem indevidamente o direito à liberdade de expressão, e se prestam ao abuso para serem utilizados para censurar direta ou indiretamente ideias dissidentes e minoritárias. Assim, os Estados devem procurar aprovar a aplicar leis que prevejam o direito de resposta e protejam a reputação por meio de ações civis, apenas se utilizando de medidas criminais naqueles casos de proteção contra a expressão que incita a violencia anárquica ${ }^{186}$.

\section{2.c Após o Relatório de 1994 e sua aplicação aos "crimes contra a honra"}

Deste o Relatorío de 1994 sobre a incompatibilidade das "leis de desacato" com a Convenção Americana, a Relatoria Especial de Liberdade de Expressão da Comissão Interamericana emitiu relatórios específicos

\footnotetext{
${ }^{184}$ Idem.

${ }^{185}$ Idem.

${ }^{186}$ Idem.
} 
sobre tais leis nos anos de 1998, 2000, 2002, e $2004^{187}$. Nestes documentos, a Relatoria fez considerações adicionais sobre o caráter de tais leis, e monitorou a situação das "leis de desacato" nos países da, como uma maneira de dar continuidade ao Relatório de 1994. As principais considerações traçadas pela Relatoria nos Relatórios subsequentes com relação ao direito à crítica disseram respeito à aplicação da doutrina estabelecida no Relatório de 1994 aos crimes contra a honra, na medida em que estes são utilizados por funcionários públicos para a defesa de sua reputação.

Assim, a Relatoria observou que, na medida em que funcionários públicos (e outras pessoas públicas) devem ter uma maior tolerância à críticas sobre suas funções públicas do que pessoas privadas, tal distinção deve estar refletida na proteção à honra e à reputação outorgada nas leis ordinárias sobre os crimes de difamação, injúria, e calúnia, uma vez que tais figuras legais poderiam ser utilizadas abusivamente por funcionários públicos, tanto quanto as "leis de desacato", para calar opiniões críticas à administração pública. Neste ponto, a CIDH esclarece que, de um ponto de vista dogmático-penal, o desacato é "simplemente una calumnia o injuria en el que el sujeto pasivo es especial (un funcionario público)"188. Assim, uma sanção penal imposta por meio das figuras dos crimes contra a honra quando utilizadas por um funcionário público acabaria por ter as mesmas consequências de paralização do discurso sobre questões públicas e da autocensura, quanto a sanção pelo crime de desacato ${ }^{189}$.

${ }^{187}$ CIDH. Informe Especial do Relator de Liberdade de Expressão de 1998. Disponível em: $<$ http://www.oas.org/es/cidh/expresion/showarticle.asp?artID=134\&IID=2>. Acesso em 8 de novembro de 2012. CIDH. Informe Anual do Relator para a Liberdade de Expressão de 2000. Disponível em: < http://www.oas.org/es/cidh/expresion/showarticle.asp?artID=136\&lID=2>. Acesso em 8 de novembro de 2012. CIDH. Informa Anual da Relatoria para Liberdade de Expressão $2002 . \quad$ Disponível em: <http://www.oas.org/es/cidh/expresion/showarticle.asp?artID=138\&lID=2>. Acesso em 8 de novembro de 2012. CIDH. Informe Anual da Relatoria para a Liberdade de Expressão de 2004. Disponível em: <http://www.oas.org/es/cidh/expresion/showarticle.asp?artID=459\&lID=2>. Acesso em 8 de novembro de 2012.

${ }^{188}$ CIDH. Informa Anual da Relatoria para Liberdade de Expressão de 2002. Op. cit. par. 21

${ }^{189}$ Idem, pars. 17-29 
Desde modo, a Relatoria concluiu que, para a proteção adequada do direito à liberdade de expressão, os Estados devem reformar também suas leis criminais relacionadas à injúria, difamação e calúnia para excluir de sua aplicação a expressão proferida contra funcionários públicos no exercício de suas funções, uma vez que não existe um interesse social imperativo que justifique a restrição da liberdade de expressão nestes casos e que a sanção criminal não é necessária ou proporcional para garantir o direito à honra e à reputação de funcionários públicos. Neste casos, esclareceu a Relatoria, apenas sanções civis poderiam ser aplicadas, sendo garantido ainda o parâmetro da "real malícia", desenvolvido pela Corte Suprema dos Estados Unidos no caso New York Times v. Sullivan: o autor da informação deveria saber que esta era falsa ou ter atuado com manifesta negligência quanto à sua falsidade ${ }^{190}$.

A determinação de que o direito à liberdade de expressão não poderia ser restringido por meio das figuras dos crimes de desacato e dos crimes contra a honra que sancionassem a expressão crítica de funcionários públicos no exercício de suas funções, foi oficialmente adotada pela Comissão Interamericana quando da aprovação da Declaração de Princípios sobre Liberdade de Expressão de 2000. Tal Declaração é aplicada até hoje pela CIDH e pela Relatoria como a positivação das proteções necessárias à para a garantia do direito à liberdade de expressão tal como previsto na Convenção Americana. Os princípios 10 e 11 tratam dos crimes contra a honra, e das "leis de desacato":

"10. As leis de privacidade não devem inibir nem restringir a investigação e a difusão de informação de interesse público. A proteção à reputação deve estar garantida somente através de sanções civis, nos casos em que a pessoa ofendida seja um funcionário público ou uma pessoa pública ou particular que se tenha envolvido voluntariamente em assuntos de interesse público. Ademais, nesses casos, deve-se provar que, na divulgação de notícias, o comunicador teve intenção de infligir dano ou que estava plenamente consciente de estar divulgando notícias falsas, ou se comportou com manifesta negligência na busca da verdade ou falsidade das mesmas.

11. Os funcionários públicos estão sujeitos a maior escrutínio da sociedade. As leis que punem a expressão ofensiva contra funcionários públicos, geralmente

${ }^{190}$ CIDH. Informe Anual do Relator para a Liberdade de Expressão de 2000, Op. cit. pars. 6-8 
conhecidas como "leis de desacato", atentam contra a liberdade de expressão e o direito à informação. ${ }^{191}$ ",

Neste sentido, o discurso político sobre assuntos de interesse público e o discurso sobre funcionários públicos no exercício de suas funções é um tipo de discurso especialmente protegido pela Convenção Americana, por sua relação fundamental com o funcionamento e desenvolvimento adequado da democracia, tendo os Estados uma menor margem de atuação na restrição de expressões deste caráter. Pelo contrário, os Estado possuem um dever de outorgar maiores proteções e garantias ao discurso referente a questões públicas. ${ }^{192}$

Em um relatório recente sobre o tema, a Comissão Interamericana resumiu sua posição a respeito da aplicação dos crimes contra a honra e das leis de desacato, demonstrando a atualidade da doutrina exposta no Relatório de 1994. Assim, para a CIDH,

"La utilización de mecanismos penales para sancionar expresiones sobre cuestiones de interes público o funcionários públicos, candidatos a ejercer cargos públicos o políticos vulnera en sí misma el artículo 13 de la Convención Americana, ya que no hay un interes social imperativo que la justifique, resulta innecesaria y desproporcionada, y además puede constituir un medio de censura indirecta dado su efecto amendrentador o inhibidor del debate sobre asuntos públicos. ${ }^{193, "}$

O problema da aplicação das "leis de desacato" e dos crimes contra a honra para sancionar a opinião crítica da administração pública foi ainda identificado pela Comissão Interamericana, já no ano de 2008, como um dos cinco temas prioritários de trabalho da Relatoria de Liberdade de Expressão, por sua continuada prevalência no hemisfério americano. Neste Relatório, a CIDH reafirma sua doutrina a respeito do tema, enfatizando que a utilização do direito penal para suprimir e sancionar opiniões consideradas "inconvenientes" ou que vão além de uma simples crítica construtiva é uma característa de regimes autoritários, não fazendo sentido em uma democracia. Na ocasião, a Relatoria concluiu:

\footnotetext{
${ }^{191}$ CIDH. Declaração de Principios sobre Liberdade de Expressão. Op. cit.

${ }^{192}$ Relatoria para a Liberdade de Expressão da Comissão Interamericana de Direitos Humanos. Marco jurídico interamericano sobre el derecho a la libertad de expresión. Op. cit. pars. 33-56.

${ }^{193}$ Idem, par. 114
} 
"El uso de los médios coercitivos del Estado para imponer una visión única del mundo o desalentar una deliberación vigorosa y abierta sobre todos los asuntos de relevancia pública, resulta incompatible con los principios que orientan los régimens democráticos, $\mathrm{y}$, en particilar, con el derecho a la libertad de expresión" $" 194$.

É importante notar que, até o momento, e ao contrário da Comissão Interamericana, a Corte Interamericana ainda não se pronunciou de maneira definitiva a respeito da compatibilidade per se com a Convenção Americana das disposições legais equivalentes às "leis de decasato" ou dos crimes contra a honra na medida em que estes potegem funcionários públicos no exercício de suas funções. No entanto, e como se verá no item seguinte, a Corte Interamericana desenvolveu em sua jurisprudência um teste tripartite com critérios restritivos a ser aplicado para análise da comptabilidade destes tipos de restrições com a Convenção Americana em casos concretos.

\section{2.d A Corte Interamericana e a expressão crítica a funcionários públicos: o caso Kimel v. Argentina}

Desde a emissão da Opinião Consultiva No. 5 de 1985, a Corte Interamericana de Direitos Humanos se pronunciou em uma série de casos contenciosos a respeito do direito à liberdade de expressão e das consequentes obrigações dos Estados para garatir sua plena vigência sob a Convenção Americana. Dentre os casos julgados envolvendo este direito, ao menos cinco dizem respeito ao uso do direito penal - em geral por meio da figura dos crimes contra a honra - para a sanção da expressão crítica de funcionários públicos no exercício de suas funções ou pessoas públicas ${ }^{195}$. Em todos estes casos, a Corte Interamericana determinou, após a análise da situação concreta, que as sanções aplicadas violavam o direito à liberdade de expressão, por não serem necessárias, proporcionais, ou não passarem

\footnotetext{
${ }^{194}$ Relatoria para a Liberdade de Expressão da Comissão Interamericana de Direitos Humanos. Una agenda hemisferica para la defensa de la libertad de expresión, par. 55

${ }^{195}$ São estes casos: Corte IDH. Caso Herrera Ullhoa v. Costa Rica. Sentença de 2 de julho de 2004. Série C No. 107; Caso Ricardo Canese v. Paraguay. Sentença 31 de agosto de 2004. Série C No. 111; Caso Kimel v. Argentina. Sentença de 2 de maio de 2008. Série C No. 177; Caso Tristán Donoso v. Panamá. Sentença de 27 de janeiro de 2009. Série C No. 193; Caso Usón Ramírez v. Venezuela. Sentença de 20 de novembro de 2009. Série C No. 207.
} 
um exame de estrita legalidade da lei penal ${ }^{196}$. Neste sentido, e até o momento, o Tribunal não encontrou qualquer situação dentre as analisadas em que a proteção do direito à honra ou à reputação de funcionários públicos por meio do direito penal constituísse uma forma legítima sob a Convenção Americana para a restrição do direito à liberdade de expressão.

Considerando a amplitude de casos julgados sobre o tema pela Corte, utilizaremos a título de exemplo um dos mais relativamente recentes julgados do Tribunal, o caso Kimel v. Argentina, o qual é demonstrativo da posição deste órgão a respeito do tema sob análise, e dos parâmetros que vêm sendo aplicados pela Corte para determinar se uma determinada restrição do direito à liberdade de expressão está ou não de acordo com a Convenção Americana. A relevância do caso em questão se dá também pelo impacto da decisão da Corte no país condenado, e da consequente internalização de parâmetros interamericanos no direito interno de países do hemisfério, como também se verá a título de exemplo no próximo item, com o estudo do caso da lei de desacato da Guatemala.

$\mathrm{O}$ caso Kimel v. Argentina diz respeito à condenação inicialmente pelo crime de calúnia e posteriormente pelo crime de injúria do historiador Eduardo Kimel pelas crítica realizada em seu livro ao juiz responsável pela investigação e processo de um massacre perpetrado durante a ditadura argentina. Na publicação, Kimel criticava o trabalho do magistrado ao afirmar que apesar do juiz ter realizado os requisitos formais da investigação, "a evidência de que a ordem do crime havia partido da entranha do poder militar paralizou a investigação, a levando a um ponto morto" ${ }^{197}$. O historiador ainda afirmou, de maneira geral, que a atuação dos juízes durante a ditadura argentina havia sido condescendente, "quando não cúmplice da repressão ditatorial" ${ }^{198}$. Em primeira instância, as cortes argentinas condenaram o jornalista pelo crime de calúnia, entendendo que

\footnotetext{
${ }^{196}$ Relatoria para a Liberdade de Expressão da Comissão Interamericana de Direitos Humanos. Marco jurídico interamericano sobre el derecho a la libertad de expresión. Op. cit. 118

${ }^{197}$ Corte IDH. Caso Kimel v. Argentina. Op. cit., par. 42

${ }^{198}$ Ibid, par. 42
} 
Kimel haveria imputado um fato criminoso ao magistrado, o qual acabou reinquadrado em segunda instância no tipo de penal de injúria, com base na ideia de que Kimel apenas havia proferido sua opinião, afetando a honra do magistrado $^{199}$.

Em sua análise, a Corte Interamericana irá aplicar o teste tripartite desenvolvido desde a opinião consultiva No. 5 pelo qual deve passar qualquer restrição do direito à liberdade de expressão pela aplicação de responsabilidades ulterior. Assim, o Tribunal determinará: 1) se a tipificação dos delitos de calúnia e injúria obecedeu à legalidade estrita que deve ser observada para a restrição do direito à liberdade de expressão pelo direito penal; 2) se a proteção da reputação de juízes configura uma finalidade legítima de acordo com a Convenção e se a via penal é idônea para alcançar tal finalidade; 3) se a restrição é necessária e 4) a estrita proporcionalidade da medida. Apenas se a sanção aplicada atender aos quatro requisitos, a restrição imposta à liberdade de expressão seria autorizada pela Convenção Americana ${ }^{200}$.

Ao analisar o primeiro requisito, a Corte Interamericana nota que, para que o uso de uma sanção penal seja realizado conforme a CADH, é preciso que o tipo penal previsto cumpra com o parâmetro da estrita legalidade requerido pelo direito criminal, devendo ser formulado de maneira expressa, taxativa e anterior, de modo que seja possível a distinção entre as condutas proibidas e aquelas autorizadas pela lei penal. O Tribunal então apontou a amplitude dos tipos penais de injúria e calúnia no direito penal Argentino, os quais foram aplicados por tribunais diferentes do Estado sobre a mesma expressão, mudando o enquadramento a conduta, e demonstrando a falta de taxatividade de embos tipos. Neste sentido, o próprio Estado argentino, no âmbito do processo internacional, reconheceu que a falta de precisões de seu marco normativo penal relativo aos crimes contra a honra afetava o direito à liberdade de expressão. Assim, a Corte

\footnotetext{
${ }^{199}$ Ibid, pars. 43-50
}

${ }^{200}$ Ibid, par. 58 
IDH concluiu que a restrição aplicada já não atendia ao primeiro requisito estabelecido pela Convenção Americana ${ }^{201}$.

Quanto ao segundo requisito, a Corte Interamericana reafirmou que a proteção da reputação e da honra de uma pessoa é um fim legítimo para restrição da liberdade de expressão, como determinado no próprio texto da Convenção Americana, mesmo se tal pessoa for um funcionário público, sendo o direito penal uma forma idônea de alcançar tal fim pela cominação de uma pena para resguardar o direito que se quer proteger. A restrição aplicada, portanto, atendeu ao segundo requisito ${ }^{202}$.

O terceiro requisito, relativo à necessidade de aplicação da medida, é aquele no qual a Corte passa a deter com maiores detalhes. Como a Comissão Interamericana e na linha da Opininão Consultiva No. 5, a Corte explicitou que, para a determinação de se uma medida é necessária, é preciso avaliar, dentre medidas alternativas capazes de alcançar a finalidade pretendida, se esta era aquela com menor lesividade para o direito que está sendo restringido, como parte do processo de harmonização de direitos. A Corte então observa que o direito penal é o meio mais restritivo e severo que pode ser utilizado pelo Estado para sancionar determinada conduta, e que a "tipificação ampla dos delitos de calúnia e injúria pode resultar contrária ao princípio de intervenção mínima e de última ratio do direito penal" ${ }^{203}$, uma vez que em uma sociedade democrática o poder punitivo do estado só deveria ser utilizado para a proteção contra ataques graves dos bens jurídicos fundamentais, sempre com relação à magnitude do dano inflingido.

Neste ponto, a Corte Interamericana ressalta que o uso do direito penal em si para a restrição do direito à liberdade de expressão não é contrario à Convenção. No entanto, pediu especial cautela por parte dos Estados no uso de tais instrumentos, devendo haver uma verdadeira ponderação quanto à gravidade da conduta, o dolo do autor, e a

\footnotetext{
${ }^{201}$ Ibid, par. 59-67

${ }^{202}$ Ibid, par. 68-71

${ }^{203}$ Ibid, par. 79
} 
característica do dano, de modo que o uso do direito penal seja realizado de maneira verdadeiramente excepcional. Nestes casos, a Corte, como a Comissão, também determina que todo o ônus da prova deve recair sobre aquele que formula a acusação. Enquanto o Tribunal Interamericano nunca invoca explicitamente a doutrina da real malícia, a Corte constata que não há um dever de um jornalista de que todos os fatos afirmados sejam verdadeiros, mas apenas uma obrigação de "constatar de forma razoável, ainda que não necessariamente exaustiva, os fatos que fundamentam suas opiniões", existindo neste sentido um direito das pessoas "a não receber uma versão manipulada dos fatos" ${ }^{204}$. No caso concreto, no entanto, e sopesando os parâmetros descritos anteriormente, a Corte conclui que o abuso de poder punitivo foi notório, considerando o caráter da expressão emitida por Kimel, sua repercurssão sobre os bens jurídicos do magistrado, e a natureza da sanção aplicada, no caso, a privação de liberdade ${ }^{205}$.

Finalmente, o Tribunal analiza o último requisito, é dizer a restrita proporcionalidade da medida, realizando uma ponderação no caso concreto entre o direito à honra e o "direito à livre crítica contra a atuação de funcionários públicos" levando em conta os seguintes parâmetros: 1) o grau em que o primeiro bem jurídico foi afetado; 2) a importância de satisfação do bem jurídico contrario; 3) se a satisfação deste bem justifica a restrição do outro ${ }^{206}$.

Assim, no caso em tela, o Tribunal determinou que direito à liberdade de expressão de Eduardo Kimel foi gravemente afetado não apenas pela imposição das sanções de pena privativa de liberdade e multa, mas pelas próprias consequências trazidas pelo processo penal, com a inscrição no registro de antecedentes penais, a estigmatização social que acarreta um processo desta natureza. No que tange a afetação do direito à honra e à reputação do magitrado, no entanto, a Corte Interamericana, adotando posição similar àquela da Comissão Interamericana em seu

\footnotetext{
${ }^{204}$ Idem.

${ }^{205}$ Ibid, par. 80

${ }^{206}$ Ibid, par. 84
} 
relatório sobre as leis de desacato de 1994, ressaltou que as "expressões concernentes à idoneidade de uma pessoa para o desempenho de um cargo público ou aos atos realizados por funcionários públicos no desempenho de suas funções" ${ }^{207}$ devem possuir uma maior proteção para que se torne possível o debate democrático. Assim, em uma sociedade democrática, funcionários públicos devem estar mais expostos ao escrutínio público, uma vez que se expuseram voluntariamente a tal controle, e que suas atividades estão inseridas na esfera do debate público, havendo portanto interesse público na expressão relativas a estas. Segundo a Corte, o pluralismo democrático requer que informações e opiniões sobre assuntos de interesse público sejam mais amplamente cieculados e acessíveis, devendo haver maior tolerância com relação a expressões de cidadãos no exercício do controle democrático, o qual "fomenta a transparência das atividades estatais e promove a responsabilidade dos funcionários públicos sobre sua gestão pública" ${ }^{208}$. Neste viés, a Corte ressaltou:

"En la arena del debate sobre temas de alto interés público, no sólo se protege la emisión de expresiones inofensivas o bien recibidas por la opinio'n pu'blica, sino tambie'n la de aquellas que chocan, irritan o inquietan a los funcionarios pu'blicos o a un sector cualquiera de la población" ${ }^{209}$.

Retornando à análise da situação concreta, o Tribunal concluiu não apenas que a expressão realizada por Kimel versava sobre temas de notório interesse público, mas configuravam também um juízo de valor crítico, e não a constatação de um fato. A Corte então ressaltou que as opiniões vertidas por Kimel não podem ser consideradas nem verdadeiras, nem falsas, e, consequentemente, não podem ser objeto de uma sanção especialmente "quando se trata de um juízo de valor sobre um ato oficial de um funcionário público no exercício de suas funções" ${ }^{210}$. Deste modo, segundo a Corte, nenhum juízo de valor pode ser submetido a requisitos de prova de sua veracidade.

\footnotetext{
${ }^{207}$ Ibid, par. 86

${ }^{208}$ Ibid, par. 87

${ }^{209}$ Ibid, par. 88

${ }^{210}$ Ibid, par. 93
} 
Com base nas considerações acima, o Tribunal concluiu que a afetação do direito à liberdade de expressão de Eduardo Kimel foi manifestamente desproporcionada com relação à afetação do direito à honra, não cumprindo com o quarto requisito imposto pela Convenção. A Corte então condenou o Estado argentino pela violação do direito à liberdade de expressão, previsto no artigo 13 da Convenção Americana, e pela violação do princípio da reserva legal, prevista no artigo 9 do $\operatorname{tratado}^{211}$.

Enquanto a Corte Interamericana até o momento não se manifestou expressamente sobre a incompatibilidade per se com a CADH do uso de "leis de desacato" ou dos tipos penais ordinários dos "crimes contra a honra" quando utilizados por funcionários públicos para a proteção de sua reputação contra expressões relacionadas ao exercício de suas funções, em todos os casos até o momento analizados pelo Tribunal envolvendo esta temática, a Corte determinou que a sanção penal aplicada havia sido desproporcional e ou desnecessária, considerando o caráter da sanção penal, o nível de escrutíneo que deve ser suportado por figuras e autoridades públicas, e a importância da liberdade de expressão no controle democrático.

Neste sentido, dentre as reparações ordenadas no Caso Kimel, a Corte Interamericana ordenou que o Estado Argentino adequasse sua legislação relativa aos "crimes contra a honra" para torná-la menos imprecisa, e adequá-la à Convenção Americana ${ }^{212}$.

Em novembro de 2009, um pouco mais de um ano após a sentença interamericana, o Estado argentino optou pela descriminalização dos crimes contra a honra quando as expressões disserem respeito a assuntos de interesse público ${ }^{213}$. A discriminalização ocorreu dezesseis anos após a Argetina descriminalizar o delito de desacato, em 1993, também com base

\footnotetext{
${ }^{211}$ Ibid, par. 95

${ }^{212}$ Ibid, par. 93

${ }^{213}$ Argentina. Congresso Nacional. Lei 26551/2009.
} 
em uma decisão proferida pelo Sistema Interamericano, na ocasião, pela Comissão Interamericana de Direitos Humanos ${ }^{214}$.

Além da Argentina, diversos outros Estados do continente americano revogaram suas "leis de desacato" nas últimas duas décadas, na medida em que estas garantiam proteções especiais a autoridades e funcionários públicos no exercício de suas funções contra opiniões ou expressões tidas como isultantes, caluniosas, difamantes ou ofensivas. Em 1998, e logo após a descriminalização pelo Estado do Paraguay do crime de desacato $^{215}$, a Comissão Interamericana havia identificado dezessete países do continente que ainda possuíam leis com tais características ${ }^{216}$. Deste então, oito destes países - Costa Rica ${ }^{217}$, Perú ${ }^{218}$, Chile ${ }^{219}$, Honduras ${ }^{220}$, Panamá ${ }^{21}$, Uruguay $^{222}$, Guatemala ${ }^{223}$, e Bolívia ${ }^{224}$ - igualmente revogaram suas leis de desacato, seja por meio de reformas legislativas, ou pelas Cortes Supremas nacionais. No que tange os "crimes contra a honra", além da Argentina, quatro Estados do continente - Uruguay ${ }^{225}$, México ${ }^{226}$, Panamá ${ }^{227}$ e El Salvador ${ }^{228}$ - recentemente também alteraram suas leis para descriminalizar

${ }^{214}$ CIDH. Informe No. 22/94. Caso 11.012 (Argentina). Solução amistosa, 20 de setembro de 1994.

215 CIDH. Informe de país sobre o Paraguay de 1998, par. 15. Disponível em: $<$ http://www.cidh.org/countryrep/paraguay01sp/cap.6.htm>. Acesso em 8 de novembro de 2012.

${ }^{216}$ CIDH. Informe Especial do Relator de Liberdade de Expressão de 1998. Op. cit.

${ }^{217}$ Costa Rica. Congresso Nacional. Lei No. 8224. Derogación del tipo penal de Desacato.

${ }^{218}$ CIDH. Informe Anual da Relatoria para a Liberdade de Expressão de 2004. Op. cit. par. 43.

219219 CIDH. Informe Anual da Relatoria para a Liberdade de Expressão de 2005, par. 43. Disponível em: <http://www.oas.org/es/cidh/expresion/showarticle.asp?artID=662\&IID=2>. Acesso em 8 de novembro de 2012.

${ }^{220}$ Ibid., par. 117

${ }^{221}$ Ibid. pars. 159,160

222 Uruguay. Presidencia da República. CM/556. Disponível em: $<$ http://archivo.presidencia.gub.uy/ web/proyectos/2008/09/CM556 26\%2006\%202008 00001.P DF $>$. Acesso 8 de novembro de 2012.

${ }^{223}$ Corte de Constitucionalidade da Guatemala. Expediente No. 1122-2005. 1 de fevereiro de 2005.

${ }^{224}$ Tribunal Constitucional da Bolícia. Sentencia Constitucional Plurinacional 1250/2012. 20 de setembro de 2012.

${ }^{225}$ Uruguay. Presidencia da República. CM/556. Op. cit.

${ }^{226}$ México. Poder Executivo do Estado. Decreto No. 460.

${ }^{227}$ CIDH. Informe Anual da Relatoria para a Liberdade de Expressão de 2007,pg. 125. Disponível em: <http://www.oas.org/es/cidh/expresion/showarticle.asp? artID=725\&lID=2>. Acesso em $8 \mathrm{de}$ novembro de 2012.

${ }^{228}$ CIDH. Informe Anual da Relatoria para a Liberdade de Expressão de 2007, par. 229. Disponível em:

$<$ http://www .oas.org/es/cidh/expresion/docs/informes/anuales/2012\%2003\%2021\%20Informe $\% 20$ Anual\%20RELE\%202011\%20impresion.pdf >. Acesso em 8 de novembro de 2012. par. 229 
tais condutas, incluir exceções para aquelas expressões relativas a funcionários públicos no exercício de suas funções ou sobre assuntos de interesse público, ou positivar a adoção do parâmetro da real malícia e de outras proteções a favor da expressão crítica sobre assuntos públicos. Além destes países, existem projetos na Colômbia, Jamaica, e no Perú para a adoção de disposições similares ${ }^{229}$.

Neste sentido, passamos agora a analizar o caso concreto da descriminalização do desacato pela Corte Constitucional da Guatemala, em ação de inconstitucionalidade proposta contra a lei. A decisão do tribunal guatemalteco tem especial relevância para este trabalho por demonstrar concretamente, e a título de exemplo, a utilização por um tribunal latinoamericano dos parâmetros estabelecidos pela Suprema Corte americana e pelos órgãos do Sistema Interamericano de Direitos Humanos no que tange o direito à crítica de funcionários e autoridades públicas em uma sociedade democrática $^{230}$.

\section{A Corte Constitucional da Guatemala e a descriminalização do desacato}

Em 2005, o comunicador Mario Roberto Fuentes Destarac, Presidente da Câmara Guatemalteca de Jornalismo, ajuizou ação de inconstitucionalidade contra os artigos $411^{231}, 412^{232}$ e $413^{233}$ do Código Penal, os quais previam

\footnotetext{
${ }^{229}$ CIDH. Relatoria para a Liberdade de Expressão. Comunicado de Imprensa R128/12. Disponível em: <http://www.oas.org/es/cidh/expresion/showarticle.asp?artID=912\&lID=2>. Acesso em 8 de novembro de 2012.

${ }^{230}$ Inicialmente, se buscava a análise da decisão do Estado da Guatemala não apenas por sua incorporação dos parâmetros internacionais e de comparados, mas também por ser a decisão judicial mais recente identificada dentre aqueles países de descriminalizaram o desacato. Sem embargo, é importante ressaltar no mês de setembro de 2012, a Bolívia descriminalizou o desacato também por uma decisão de seu Tribunal Constitucional. Por uma questão temporal, no entanto, não foi possível realizar uma análise profunda daquela decisão, a qual também remete a parâmetros internacionais, assim como à própria decisão do Tribunal Constitucional da Guatemala. ${ }^{231}$ O artigo 411 do Código Penal da Guatemala previa: "Quien ofendiere en su dignidad o decoro, o amenazare, injuriare o calumniare a cualquiera de los Presidentes de los Organismos del Estado, será sancionado con prisión de uno a tres años."

${ }^{232} \mathrm{O}$ artigo 412 do Código Penal da Guatemala previa: "Quien amenazare, injuriare, calumniare o de cualquier otro modo ofendiere en su dignidad o decoro, a una autoridad o funcionario en el ejercicio de sus funciones o con ocasión de ellas, será sancionado con prisión de seis meses a dos años".
} 
os delitos de desacato aos Presidentes dos Órgãos os Estados, desacato à autoridade, e sobre a prova da imputação. Tais delitos sancionavam as ameaças, injúrias, calúnias e ofensas à dignidade ou decoro dos Presidentes dos três órgãos do Estado e de funcionários públicos no exercício de suas funções $^{234}$. A alegação era de que o texto dos artigos estava em desacordo com o artigo 35 da Constituição do país, o qual prevê:

"No constituyen delito o faltas las publicaciones que contengan denuncias, críticas o imputaciones contra funcionários ou empleados públicos por actos efectuados en el ejercicio de sus cargos. Los funcionários o empleados públicos podrán exigir un tribunal de honor, integrado en la forma que determine la ley, declare que la publicación que los afecta se basa en hechos inexactos o que los cargos que se lês hacen son infundados."

Tendo em vista o texto constitucional, as alegações dos autores inicialmente se relacionaram mais ao direito penal e ao processo do que à proteção per se do direito à liberdade de expressão, alegando que nem a pena privativa de liberdade e a exceptio veritatis não poderiam ser impostas para a crítica contra funcionários públicos, uma vez que o procedimento que deveria ser instaurado nestes casos seria a do "tribunal de honra", e não um processo criminal. Posteriormente, no entanto, a inicial foi emendada para trazer os parâmetros desenvolvidos pela Corte e a Comissão Interamericana de Direitos Humanos a respeito do direito à liberdade de expressão e das "leis de desacato" ${ }^{235}$. Na decisão final da Corte Constitucional, é especialmente com relação ao direito material à crítica de funcionários públicos que o Tribunal guatemalteco irá se basear ao determinar a inconstitucionalidade dos artigos arguidos, como se passa a ver.

Em 1 de fevereiro de 2006, a Corte Constitucional da Guatemala emitiu sua decisão sobre ação de inconstitucionalidade contra os artigos 411, 412 e 413 do Código Penal guatemalteco, por cinco votos a dois. O Tribunal coloca a relevância da questão apresentada como possibilidade de

\footnotetext{
${ }^{233}$ O artigo 413 do Código Penal da Guatemala previa: "Al acusado de injuria contra funcionario o autoridades públicas, sí se admitirá prueba sobre la verdad de la imputación si se tratare de hechos concernientes al ejercicio de su cargo. En este caso será absuelto si probare ser cierta la imputación".

${ }^{234}$ Corte de Constitucionalidade da Guatemala. Expediente No. 1122-2005. Op. cit. pg 3 e 4

${ }^{235} \mathrm{Ibid}$, pg 5
} 
uma violação da Constituição pela "eventual restrição à livre emissão de pensamento de expressão pela coexistência de sanções penais que restrinjam o exercício a tal direito" ${ }^{236}$. Neste viés, a Corte inicia suas considerações enfatizando a importância do direito à liberdade de expressão em uma sociedade democrática, na medida em que permite a emissão e troca de juízos de valores por cidadãos buscando a tomada de decisões, se utilizando ainda os parâmetros desenvolvidos pela Corte Interamericana na Opinião Consultiva No. 5 ao constatar a dimensão social deste direito ${ }^{237}$.

O Tribunal guatemalteco então invoca o princípio No. 11 da Declaração de Princípios de Liberdade de Expressão da Comissão Interamericana, o qual, como apontado no item anterior, prevê que as "leis de desacato" atentam conta o direito à liberdade de expressão, uma vez que funcionários públicos estão sujeitos a um maior escrutínio da sociedade, não devendo receber maior proteção. Nesta mesma linha, a Corte Constitucional da Guatemala compartilha o entendimento da $\mathrm{CIDH}$, acrescentando que tais leis levam à autocensura da crítica necessária em uma sociedade democrática para o escrutínio e o controle das funções públicas. Neste sentido, a probição de tal crítica seria atentatória a um regime constitucional que tem no povo a soberania. $\mathrm{O}$ "direito à critica da conduta oficial", como afirma o Tribunal, deve ser garantido ao povo, especialmente no que concerne a atuação dos Presidentes dos três órgãos de Estados para os quais o poder soberano foi delegado, e especialmente quando sua conduta ultrapassar os limites determinados pelas leis e pela Constituição ${ }^{238}$.

A Corte Constituconal também invoca o princípio da legalidade penal, o qual determina que, em uma sociedade democrática, é fundamental que as leis que estabeleçam sanções penais sejam claras e taxativas, de modo que seja possível distinguir entre uma conduta lícita e ilícita. A Corte acrescenta que, em regimes democráticos, o direito penal deve ser utilizado

\footnotetext{
${ }^{236} \mathrm{Ibid}$, pg 5-6

${ }^{237} \mathrm{Ibid}$, pg 6

${ }^{238}$ Idem.
} 
como a ultima ratio, não devendo ser utilizado de maneira abusiva para o menoscabo de direitos fundamentais por meio da sanção de condutas que "de acordo com o espírito do ordenamento constitucional, não poderiam ser punidas" ${ }^{239}$. Deste modo, o Tribunal conclui:

"Por ello, las leyes que mediante la regulación de tipos y sanciones penales propendan a una protección indebida e irrazonable a un funcionario e impidan con ello es escrutinio público de su labor pública (Auditoría Social), atentan contra el derecho a la libre expresión del pensamiento, y, por ende, afrentan al propio régimen democrático. ${ }^{240,}$

Neste viés, a Corte acrescenta, novamente com base na jurisprudência de tribunais internacionais de direitos humanos, que o pluralismo democrático demanda que sejam protegidas não apenas aquelas expressões recebidas favoravelmente, mas também aquelas ofensivas, chocantes, e inquietantes. Tal pluralismo não significa o exercício sem limites do direito à liberdade de expressão. No entanto, e no que se trata da expressão diriga a funcionários públicos pelo exercício de suas funções, o Tribunal determina que Constituição não autoriza o uso de sanções penais, mas apenas de sanções civis, pelo alto poder de inibição que possui o direito penal, e a consequente autocensura à crítica de cidadãos ao desempenho da função pública ${ }^{241}$.

$\mathrm{Na}$ análise concreta dos tipos penais impuganados, a Corte identifica três elementos em comum com os diferentes tipos de desacato: 1) o sujeito ativo como funcionários públicos; 2) o sujeito passivo como um particular; 3) o elemento material como a ofensa à dignidade ou decoro, determinado subjetivamente pelo ofendido, especialmente no caso da crítica política, a qual tende a implicar em juízos de valor, e não de fato. O Tribunal constata que crimes como a ameaça, a injúria e a calúnia já estão previstos no Código sob outros tipos penais, o que leva a que o desacato seja utilizado como um método de repressão à "crítica e aos juízos de valor e opiniões de pessoas que podem ser consideradas adversárias políticas" ${ }^{242}$. Assim, a

\footnotetext{
${ }^{239}$ Idem.

${ }^{240}$ Idem.

${ }^{241}$ Idem.

${ }^{242}$ Idem.
} 
Corte conclui que não existe um bem jurídico autônomo que mereça a tutela dos tipos impugnados, é dizer, que mereça uma proteção adicional "a respeito de críticas, imputações ou comentários de que não dispõe os particulares e [que gera] um efeito disuasivo em quem deseje participar do debate público" ${ }^{243}$. Tal efeito, ressalta a Corte, é agravado pelos tipos penais carecem de clareza na distinção entre juízos de fato e de valor.

Ainda para sustentar a probição da sanção criminal à crítica realizada sobre a gestão pública ou funcionários públicos, o Trubunal da Guatemala cita os precedentes da Suprema Corte americana no caso New York Times $v$. Sullivan, e da Comissão Interamericana em seu Relatório sobre as "leis de desacato" de 1994, frisando a conclusão de ambos os documentos de que normas deste caráter são ilegitimamente utilizadas em sociedades democráticas para silenciar ideias impopulares e suprimir o debate público. Assim, e com base nos fundamentos citados, a Corte Constitucional concluiu pela inconstitucionalidade dos artigos 411 e 412 do Código Penal $^{244}$.

Finalmente, a respeito do artigo 413 do Código Penal, o qual previa a possibilidade da exceção da verdade nos casos de injúrias cometidas contra funcionários públicos sobre fatos imputados com relação a seu cargo, o Tribunal guatemalteco determinou que tal exceção não configura uma proteção suficiente à liberdade de expressão. Pelo contrário, a Corte afirmou que o artigo que prevê a exeção em si gera o mesmo efeito disuasivo que os tipos de desacato já declarados inconstitucionais, por gerar a inversão do ônus da prova pelo cometimento de um delito, atentando contra o princípio da presunção de inocência. O Tribunal Constitucional igualmente declarou a inconstitucionalidade da norma ${ }^{245}$.

Conforme se buscou demonstrar neste segundo capítulo, durante o século XX, tribunais nacionais e órgãos internacionais de direitos humanos do continente americano judicializaram as bases político-filosóficas

\footnotetext{
${ }^{243}$ Ibid. 7, 8

${ }^{244}$ Ibid. 8

${ }^{245}$ Idem.
} 
delimitadas no primeiro capítulo, declarando a existência de um direito à crítica a autoridades e funcionários públicos no exercício de suas funções em uma sociedade democrática, e a necessidade de proteção especial desta expressão, seja por meio da aplicação de parâmetros protetores como a doutrina da "real malícia", seja pela necessidade de descriminalização daquelas leis que particularmente tutelam, por meio do direito penal, a honra e reputação de funcionários públicos contra expressões críticas dos mesmos, como as leis de desacato ou de sedição. No capítulo seguinte, passaremos a analizar o marco normativo criminal brasileiro atual no que diz respeito à crítica contra funcionários públicos, sua compatibilidade com os parâmetros explicitados, assim como as mudanças previstas no anteprojeto do novo Código Penal. 


\section{Capítulo III: o Código Penal brasileiro e a proteção especial a autoridades e funcionários públicos no exercício de suas funções}

O Direito Penal brasileiro prevê de maneira especial a sanção da crítica a funcionários públicos no exercício de suas funções e a altas autoridades públicas. Neste sentido, o Código Penal brasileiro de 1940 conta com a figura do crime de "desacato à autoridade" (artigo 331 246 ), assim como com uma cláusula de aumento de pena relativa a todos os crimes contra a honra (injúria, calúnia e difamação) quando estes são cometidos contra o Presidente da República ou funcionários públicos no exercício de suas funções (artigo 141 247 ). Deste modo, o direito penal brasileiro prevê duas formas de proteção especial à honra e à reputação de funcionários públicos no exercício de suas funções contra ofensas, críticas ou insultos que poderiam ser utilizadas contra estes pela população em geral. Além dos tipos penais em si, outras disposições de caráter processual também são delimitadas para outorgar maior proteção à honra de funcionários e autoridades públicas, como será visto abaixo.

No entanto, e como será demonstrado, os doutrinadores brasileiros criminalistas no geral não contestam tais figuras penais, e tampouco discutem as possíveis consequências destas sanções para o direito à liberdade de expressão em uma sociedade democrática. Pelo contrário, a doutrina, nas ocasiões em que busca justificar a proteção especial, o faz por uma lógica de proteção do Estado e da administração pública, e não da necessidade de uma proteção maior da expresão crítica proferida por cidadãos. Neste sentido, não há na doutrina analisada sequer discussão

\footnotetext{
${ }^{246}$ O artigo 331 do Código Penal brasileiro prevê: "Art. 331 - Desacatar funcionário público no exercício da função ou em razão dela: Pena - detenção, de seis meses a dois anos, ou multa".

${ }^{247}$ O artigo 141 do Código Penal brasileiro prevê: "Art. 141 - As penas cominadas neste Capítulo aumentam-se de um terço, se qualquer dos crimes é cometido: I - contra o Presidente da República, ou contra chefe de governo estrangeiro; II - contra funcionário público, em razão de suas funções;"
} 
sobre um possível conflito de direitos entre a liberdade de expressão e o direito à honra, e a doutrina parece partir do pressuposto de que o tipo de expressão que poderia ser enquadrado em tais figuras criminais é, a priori, não protegido pelo direito, e, pelo contrário, deve ser sancionado.

\section{Os códigos criminais de 1830 e de 1890}

Segundo Heleno Fragoso, a origem dos crimes contra a honra e no direito brasileiro remonta à sua existência no direito romano, que punia a expressão injúriosa realizada com publicidade, e que gerasse um perigo com base à ordem pública ${ }^{248}$, sendo considerada particularmente "atroz" a injúria realizada contra figuras de autoridade, como magistrados, ascendentes e patronos $^{249}$. Neste sentido, enquanto não havia no direito antigo um crime autônimo referente à expressão que atentasse contra a reputação ou honra de um funcionário público, a condição da pessoa atingida era considerada, uma circunstância agravante para o estabelecimento da pena ${ }^{250}$. Especialmente na Idade Média, quando a criminalização de tais condutas persiste, as penas para a expressão crítica de autoridades são particularmente severas e arbitrárias ${ }^{251}$.

Apesar destes antecentes, tanto Fragoso como Nelson Hungria apontam o Código Penal de Napoleão de 1810 como a principal influência no direito brasileiro e no direito latino-americano para a tipificação per se dos crimes contra a honra e a criminalização do desacato ${ }^{252}$. Hungria aponta que o Código de 1810 foi primeira legislação a distinguir subespécies de crimes contra a honra, separando o tipo da calúnia do da injúria e da difamação, e determinando que estas últimas diziam respeito a expressões

\footnotetext{
${ }^{248}$ FRAGOSO, Heleno. Lições de Direito Penal. Vol. 1. $2^{\text {a }}$ Edição. São Paulo: José Bushatsky, São Paulo, 1962, p. 139.

${ }^{249}$ Ibid. p. 140

${ }^{250}$ FRAGOSO, Heleno. Lições de Direito Penal. Vol. 4. $2^{\text {a }}$ Edição. São Paulo: José Bushatsky, São Paulo, 1965, p. 1154.

${ }^{251}$ Idem.

${ }^{252}$ HUNGRIA, Nelson. Comentários ao Código Penal. Vol. VI. 4a Edição. Rio de Janeiro: Forense, 1958, pág. 67.
} 
meramente ofensivas, mas não necessariamente falsas ${ }^{253}$, sendo admissível portanto a prova da verdade pelo réu apenas no primeiro caso. Por sua vez, Fragoso aponta que é também com o código de Napoleão que a ofensa e o desrespeito a funcionários públicos no exercício de suas funções se torna um tipo penal autônomo ${ }^{254}$.

Na linha do Código Napoleônico, o Código Penal do Império de 1830 distinguia entre a calúnia e a injúria, definindo a primeira como a atribuição de um fato criminoso a alguém, que gere uma ação judicial pública. Nestes casos, era possível ao réu provar a verdade de suas afirmações, de modo que ficasse isento de pena ${ }^{255}$. Já injúria era definida como a imputação de um fato que expusesse o ofendido ao ódio ouao desprezo público, ou como a imputação de vícios e fatos nnao específicos, ou discursos e gestos insultantes na opinião pública ou que pudessem prejudicar a reputação de alguém ${ }^{256}$. Neste sentido, o tipo penal parecia configurar uma mistura dos tipos de contemporâneos de difamação e injúria. Assim como o Código Penal atual, o Código Imperial já previa a possibilidade de prova da verdade dos fatos imputados também na injúria, naqueles casos em que o crime fosse cometido por autoridades públicas "sobre os deveres dos seus empregos" $" 257$. Não obstante tal possibilidade, o Código de 1830 previa o aumento da pena quando os crimes de calúnia e injúria fossem cometidos contra "Depositário, ou Agentes de Autoridade publica, em razão do seu officio", assim como a aplicação da pena em

\footnotetext{
${ }^{253}$ FRAGOSO, Heleno. Lições de Direito Penal. Vol. 1. Op. cit. p. 38

${ }^{254}$ FRAGOSO, Heleno. Lições de Direito Penal. Vol. 4. Op. cit. p. 1155

${ }^{255}$ Art. 229 do Código Penal de 1830: "Julgar-se-ha crime de calumnia, o attribuir falsamente a algum um facto, que a lei tenha qualificado criminoso, e em que tenha lugar a acção popular, ou procedimento official de Justiça". "Art. 234. O que provar o facto criminoso imputado, ficará isento de toda a pena."

${ }^{256}$ Art. 236 do Código Penal de 1830: "Julgar-se-ha crime de injuria: $1^{\circ} \mathrm{Na}$ imputação do um tacto criminoso não comprehendido no artigo duzentos e vinte e nove. $2^{\circ} \mathrm{Na}$ imputação de vicios ou defeitos, que possam expôr ao odio, ou desprezo publico. $3^{\circ} \mathrm{Na}$ imputação vaga de crimes, ou vicios sem factos especificados. $4^{\circ}$ Em tudo o que pôde prejudicar a reputação de alguem. $5^{\circ} \mathrm{Em}$ discursos, gestos, ou signaes reputados insultantes na opinião publica".

${ }^{257}$ Art. 239 do Código Penal de 1830: "As imputações feitas a qualquer Corporação, Depositario, ou Agente de Autoridade publica, contendo factos ou omissões contra os deveres dos seus empregos, não sujeitam a pena alguma, provando-se a verdade dellas. Aquellas porém que contiverem factos da vida privada, ou sejam contra empregadas publicos, ou contra particulares, não serão admittidas á prova".
} 
dobro quando os crimes fossem cometidos contra altas autoridades, como o Imperador, a Assembleia Legislativa, o Príncipe Imperial, a Família Imperial, e membros das Câmaras Legislativas em razão do exercício de suas funções ${ }^{258}$.

Com a entrada em vigor do Código de 1890, o desacato é pela primeira vez codificado no direito brasileiro, outorgando uma tutela penal especial explicitamente às ofensas dirigidas diretamente a funcionários públicos no exercício de suas funções ${ }^{259}$. Apesar de não mais proteger especialmente a honra do Imperador ou de outras altas autoridades do Estado, o Código ainda manteve o aumento de pena dos crimes de injúria e calúnia quando estes fossem cometidos contra autoridades públicas ou contra qualquer agente ou depositário de autoridade pública, positivando a dupla proteção atualmente existente à honra e a reputação de tais agentes estatais $^{260}$. O Código também aumentou no geral as penas cominadas

\footnotetext{
${ }^{258}$ Art. 231 do Código Penal de 1830: "Se a calumnia fôr contra qualquer Depositario, ou Agente de Autoridade publica, em razão do seu officio. Penas - de prisão por seis a dezoito mezes, e de multa correspondente á metade do tempo." Art. 242: "As calumnias, e as injurias contra o Imperador, ou contra a Assembléa Geral Legislativa, serão punidas com o dobro das penas estabelecidas nos artigos duzentos e trinta, e duzentos e trinta e tres". Art. 243: "As calumnias, e as injurias feitas a todos, ou a cada um dos Agentes do Poder Executivo, não se entendem directa, nem indirectamente feitas ao Imperador". Art. 244: "As calumnias, e as injurias contra o Regente, ou a Regencia, o Principe Imperial, a Imperatriz, ou contra cada uma das Camaras Legislativas, serão punidas com o dobro das penas estabelecidas nos artigos duzentos trinta e um, duzentos trinta e tres, duzentos trinta e sete paragrapho segundo, e duzentos e trinta e oito". Art. 245: "As calumnias, e as injurias contra alguma das pessoas da Familia Imperial, ou contra algum dos membros das Camaras Legislativas, em razão do exercido das suas attribuições, serão punidas com o dobro das penas estabelecidas nos artigos duzentos trinta e dous, duzentos trinta e tres, duzentos trinta e sete paragrapho terceiro, e duzentos trinta e oito".

${ }^{259}$ Art. 134 do Código Penal de 1890: "Desacatar qualquer autoridade, ou funccionario publico, em exercicio de suas funcções, offendendo-o directamente por palavras ou actos, ou faltando á consideração devida e á obediencia hierarchica: Pena - de prisão cellular por dous a quatro mezes, além das mais em que incorrer. Paragrapho unico. Si o desacato for praticado em sessão publica de camaras legislativas ou administrativas, de juizes ou tribunaes, de qualquer corporação docente ou dentro de alguma repartição publica: Pena - a mesma, com augmento da terça parte".

${ }^{260}$ Art. 316 do Código Penal de 1890: "Si a calumnia for commettida por meio de publicação de pamphleto, impresso ou lithographado, distribuido por mais de 15 pessoas, ou affixado em logar frequentado, contra corporação que exerça autoridade publica, ou contra agente ou depositario desta e em razão de seu officio: Penas - de prisão cellular por seis mezes a dous annos e multa de $500 \$$ a 1:000\$000. $\S 1^{\circ} \mathrm{Si}$ commettida contra particular, ou funccionario publico, sem ser em razão do officio: Penas - de prisão cellular por quatro mezes a um anno e multa de $400 \$$ a $800 \$ 000$." Art. 319: "Si a injuria for commettida por qualquer dos meios especificados no art. 316: $\S 1^{\circ}$ Contra corporações que exerçam autoridade publica ou contra qualquer agente ou depositario de autoridade publica: Penas - de prisão cellular por tres a nove mezes e multa de $400 \$$ a $800 \$ 000$. § $2^{\circ} \mathrm{Si}$ contra particular, ou funccionario publico, sem ser em razão do officio: Penas - de prisão cellular por dous a seis mezes e multa de $300 \$$ a $600 \$ 000 "$.
} 
relativas aos crimes contra a honra, demonstrando a ampliação da tutela penal no que diz respeito a estes tipos ${ }^{261}$.

\section{O Código Penal de 1940}

\section{2.a A legislação dos "crimes contra a honra" em termos gerais}

O atual Código Penal brasileiro pouco inovou em relação aos códigos anteriores de 1830 e de 1890 no que diz respeito à proteção especial outorgada à honra e à reputação de autoridades públicas no exercício de suas funções, da qual não usufruem os demais membros das população. Pelo contrário, o Código, aprovado em 1940, durante a vigência do Estado Novo, outorga uma maior proteção particularmente à honra e à reputação do Presidente da República, aumentando ainda para mais que o dobro a pena cominada para o crime de desacato prevista na legislação anterior $^{262}$, como se verá mais adiante.

Em termos gerais, a legislação atual trás três tipos penais previstos no capítulo relativo aos "Crimes contra a Honra": a calúnia ${ }^{263}$, a difamação $0^{264}$, e a injúria ${ }^{265}$. Segundo a doutrina, os dois primeiros tipos tutelam como bem jurídico a honra objetiva, isto é, a reputação e o lugar da pessoa na sociedade, enquanto a injúria tutela a honra subjetiva, é dizer, a opinião que uma pessoa tem de si mesma. Deste modo, tanto a calúnia quanto a difamação dirão respeito à imputação de fatos determinados a uma pessoa que lhe possa afetar a reputação, enquanto a injúria tratará de

\footnotetext{
${ }^{261}$ Deste modo, a título de exemplo, a prisão por calúnia cometida contra agentes públicos no exercício da função, que era até dezoito meses, passou a ter como pena até dois anos.

${ }^{262}$ Neste sentido, enquanto o Código de 1890 previa a pena de dois a quatro meses para o crime de desacato, o atual Código prevê uma pena de seis meses a dois anos.

${ }^{263}$ Art. 138 do Código Penal Brasileiro: "Caluniar alguém, imputando-lhe falsamente fato definido como crime: Pena - detenção, de seis meses a dois anos, e multa. $\S 1^{\circ}$ - Na mesma pena incorre quem, sabendo falsa a imputação, a propala ou divulga. $\S 2^{\circ}$ - É punível a calúnia contra os mortos."

${ }^{264}$ Art. 139 do Código Penal Brasileiro: "Difamar alguém, imputando-lhe fato ofensivo à sua reputação: Pena - detenção, de três meses a um ano, e multa".

${ }^{265}$ Art. 140 do Código Penal Brasileiro: "Injuriar alguém, ofendendo-lhe a dignidade ou o decoro: Pena - detenção, de um a seis meses, ou multa".
} 
expressões possíveis de ofender a “dignidade ou decoro" da vítima, como esta se percebe ${ }^{266}$.

A doutrina determina que os tipos penais contra a honra são crimes formais, e que consequentemente não é sequer necessária a prova de que houve um dano efetivo à honra ou à reputação da pessoa, mas apenas que a expressão foi feita com o dolo específico de caluniar, difamar, ou injuriar ${ }^{267}$. Alguns autores ainda apontam que certos termos ou frases seriam suficientes em si para a prova de tal dolo, por seu caráter inerentemente ofensivo à honra ${ }^{268}$.

No que se trata especificamente do crime de calúnia, a doutrina parece indicar que o dolo a ser provado pelo autor da ação seria aquele de que o réu tinha consciência de que fato criminoso imputado era falso, ou atuou de maneira negligente para fazer tal averiguação ${ }^{269}$. Enquanto este padrão parece inicialmente indicar um critério similar à doutrina da "real malícia", o ônus da prova quanto à falsidade ou verdade do fato criminoso imputado recai sobre réu, com a positivação da cláusula de "exceção da verdade", a qual permite ao réu a prova em juízo de que tal fato não era falso $^{270}$. Tal inversão do ônus da prova é vista pela doutrina como uma garantia do réu, e em nenhum momento os autores analizados contestam uma possível violação do princípio da presunção de inocência que poderia causar tal dispositivo. Por outro lado, é importante ressaltar que a exceção da verdade não é no geral aplicável aos crimes de difamação e de injúria, uma vez que o primeiro diz respeito à propagação de fatos danosos à reputação de alguém (independentemente de estes serem falsos ou

\footnotetext{
${ }^{266}$ FRAGOSO, Heleno. Lições de Direito Penal. Vol. 1. Op. cit. p. 143, DAMÁSIO, E. De Jesus. Direito Penal-Parte Especial.p. 201-204; GRECO, Rogério. Op. cit. p. 458

${ }^{267}$ FRAGOSO, Heleno. Lições de Direito Penal. Vol. 1. Op. cit. p. 144, DAMÁSIO, E. De Jesus. Direito Penal-Parte Especial. p. 204, HUNGRIA, Nelson. Op. cit. p. 41

${ }^{268}$ Neste sentido, HUNGRIA, Nelson. Op. cit. p. 53

${ }^{269}$ HUNGRIA, Nelson. Op. cit. p. 69; GRECO, Rogério. Curso de Direito Penal. Vol. II. Niterói: Imprenta, 2007, pp. 422-429

${ }^{270}$ Art. $138, \S 3^{\circ}$ do Código Penal Brasileiro: "Admite-se a prova da verdade, salvo: I - se, constituindo o fato imputado crime de ação privada, o ofendido não foi condenado por sentença irrecorrível; II - se o fato é imputado a qualquer das pessoas indicadas no $\mathrm{n}^{\circ}$ I do art. 141; III - se do crime imputado, embora de ação pública, o ofendido foi absolvido por sentença irrecorrível."
} 
verdadeiros), e a injúria não tem como objeto expressões factuais, mas sim juízos de valor ${ }^{271}$.

No geral, os crimes contra a honra, por se configurarem crimes de menor potencial ofensivo, são processados por meio de ação penal privada, e julgados pelo Juizado Especial Criminal, sendo portanto aplicáveis disposições processuais como a transação penal e a suspensão condicional do processo $^{272}$.

\section{2.b disposições específicas dos crimes contra a honra relativas a funcionários e autoridades públicas no exercício de suas funções.}

Enquanto diversas disposições relativas aos crimes contra a honra já seriam contestáveis per se à luz dos parâmetros internacionais e de direito comparado indicados no capítulo 2 desta monografia - como, por exemplo, a inversão do ônus da prova, a criminalização de juízos de opinião, e a amplitude e não-taxatividade de tais tipos - é a proteção especial outorgada a autoridades públicas e funcionários públicos no exercício de suas funções que acaba por impactar de sobremaneira o direito à liberdade de expressão no contexto de uma sociedade democrática, anulando o direito à crítica ao governo e seus representantes. Conforme será demonstrado, esta proteção especial é refletida em toda a lógica dos dispositivos dos crimes contra a honra, assim como no tipo penal em si do desacato.

O principal dispostivo que demonstra tal proteção é o aumento de pena trazido pelo art. 141, I e II de até um terço para todos os crimes contra a honra quando cometidos contra o Presidente da República ou funcionários públicos no exercício de suas funções. Deste modo, o art. 141 inverte os parâmetros de proteção estabelecidos no direito comparado e internacional quanto ao nível de proteção que deve ser outorgado a estas figuras, protegendo especialmente sua honra e reputação contra críticas, ofensas e

${ }^{271}$ Neste sentido, GRECO, Rogério. Op. cit. p. 436; MIRABETE, Julio \& FABBRINI, Renato. Manual de Direito Penal. Parte Especial, Vol. II. Edição 28a. São Paulo: Atlas, 2011, p. 131 HUNGRIA, Nelson. Op. cit. p. 38; FRAGOSO, Heleno. Lições de Direito Penal. Vol. 1. Op. cit. p. 156.

${ }^{272}$ Neste sentido, ver artigos 61, 72, 76 e 89 da Lei 9.099 de 1990. 
insultos. Nesta ótica, o aumento de pena pode ser equiparado em si a uma "lei de desacato", ao aplicarmos a definição da Comissão Interamericana de que tais leis são aquelas que penalizam especificamente "a expressão que ofende, insulta, ou ameaça um funcionário público no desempenho de suas funções oficiais"273. A proteção especial outorgada ao Presidente também remete às leis de difamação sediciosa analizadas no primeiro capítulo, na medida que se busca a proteção especial da honra do Governo e de suas altas autoridades.

Como se passará a ver, as justificativas apresentadas tanto pela doutrina clássica como a contemporânea para o aumento de pena neste caso são dadas em termos similares daquelas já apontadas pela CIDH para a fundamentação da existência de "leis de desacato", como a necessidade de proteção da ordem pública e da autoridade da administração pública. A justificativa para evitar a desordem também remete àquelas oferecidas em termos políticos durante os debates a respeito de Lei de Sedição de 1798. Não obstante, enquanto o direito à liberdade de expressão permeava todos os aspectos de tal debate nos Estados Unidos, a doutrina penal brasileira não problematiza ou reconhece a existência de um possível confronto entre a liberdade de expressão e os direitos à honra e à reputação - mesmo naqueles casos onde há a proteção especial de funcionários públicos no exercício de suas funções.

Neste sentido, Nelson Hungria, relator do anteprojeto do atual Código Penal, justifica a existência do dispositivo que agrava a pena ao afirmar que a ofensa realizada contra funcionários públicos no exercício de suas funções não atingem apenas a dignidade destes, "senão também a dignidade e o prestígio da função por ele exercida em nome e por delegação do Estado", concluindo que a proteção especial é dispensada à função

\footnotetext{
${ }^{273}$ Neste sentido, a título de exemplo, a Relatoria de Liberdade de expressão da CIDH configuou como uma "lei de desacato" o crime previsto no art. 162 do Código Penal boliviano, o qual previa como delito a ação de "calunia, injuriar ou difamar um funcionário público no exercício de suas funções ou por causa delas". http://www.oas.org/es/cidh/expresion/showarticle.asp?artID=912\&lID=2 Conforme já indicado no capítulo 2, tal dispositivo foi em 20 setembro de 2012 declarado inconstitucional pelo Tribunal Constitucional da Bolívia.
} 
pública $\mathrm{em} \mathrm{si}^{274}$. Quanto à tutela especial da honra do Presidente por meio do agravo de pena, Hungria constata que a mera "magnitude" se deu cargo "reclama para sua pessoa, sob o duplo ponto de vista da vida pública e privada, a máxima reverência" ${ }^{275}$. Por sua vez, Heleno Fragoso frisa a "alta relevância política que tem a função do Presidente" como fundentação para tal aumento de pena. Quanto aos funcionários públicos, o doutrinador apena constata que a lei "visa proteger, de maneira especial, a pessoa do servidor público, no exercício de suas funções" ${ }^{276}$. Portanto, já nos doutrinados clássicos é possível constatar a lógica de proteção do Estado e seus representantes contra a opinião crítica e ofensiva por meio do direito penal, uma vez que tal crítica diminuiria a dignidade da administração pública ante a população. É possíve argumentar que, enquanto este raciocício poderia ser aplicado ao contexto no qual o Código Penal foi aprovado em 1940, a manutenção de tais dispositivos após a Constituição de 1988, com seus princípios democráticos e de soberia do povo, seria merecedora de maiores considerações por parte da doutrina contemporânea de direitos penal. No entanto, no universo de autores estudados, não parece haver qualquer tentativa significativa de atualização a respeito da fundamentação de tal dispositivo.

Deste modo, Damásio de Jesus justifica a proteção especial outorgada a funcionários públicos com base na necessidade de "resguardo da honorabilidade do exercício da função pública"277, sem maiores considerações quanto ao aumento de pena. Por sua vez, Julio Fabbrini Mirabete, em termos similares ao de Nelson Hungria, afirma que a proteção outorgada aos funcionários públicos visa a proteção do respeito à sua função, é dizer, à administração pública, uma vez que "esse respeito se comunica necessariamente àquele que a desempenha no cumprimento do

\footnotetext{
${ }^{274}$ HUNGRIA, Nelson. Op. cit. p. 111 e 112

${ }^{275}$ Idem.

${ }^{276}$ FRAGOSO, Heleno. Lições de Direito Penal. Vol. 1. Op. cit. p. 161

${ }^{277}$ DAMÁSIO, E. De Jesus. Direito Penal - Parte Especial. 4o. Volume. 13a Edição. São Paulo: Saraiva, 2003, p. 223.
} 
dever" ${ }^{278}$. Quanto à proteção da honra do Presidente, o autor constata que "a relevância e a dignidade desses cargos, a necessidade de serem mantidos intactos seu prestígio e autoridade e a consideração devida àquele que encarna a soberania e a honorabilidade de qualquer país" impõe uma maior proteção a estas pessoas ${ }^{279}$. Na mesma linha, tratando do Presidente Rogério Greco leciona que "[a] importância do cargo ocupado por determinadas pessoas faz com que o Estado tente preservá-las ao máximo possível" ${ }^{280}$, sem, no entanto, problematizar ou justificar o aumento da pena em um terço para funcionários públicos no exercício de suas funções ${ }^{281}$.

A defesa especial da honra do Presidente da República e de funcionários públicos no exercício de suas funções é refletida em outros dispostivos relativos ao crimes contra honra. De especial importância e gravidade é o art. $138, \S 3^{\text {o282 }}$, que proíbe o uso da "exceção da verdade" quando se trata de uma calúnia proferida contra o Presidente da República, efetivamente tornando crime a imputação de um fato criminoso verdadeiro contra o Presidente. Este dispositivo não apenas proíbe o controle democrático sobre a atuação do principal representante do povo soberano de uma nação, mas também criminaliza aqueles que o buscam exercer, refletindo a doutrina de William Blackstone da Inglaterra do século XVIII, a qual buscava a sanção de qualquer expressão, mesmo aquelas verdadeiras, caso estas pudessem trazer desprestígio contra aqueles que as proferiram.

Hungria justifica tal disposição normativa sob a lógica que o Presidente não poderia ser acusado de uma ação criminosa por alguém que não teria a prerrogativa constitucional para tal, uma vez que tal ação exporia o Presidente "ao desprestígio de sua autoridade e a vexame incompatível

\footnotetext{
${ }^{278}$ MIRABETE, Julio \& FABBRINI, Renato. Op. cit. 140

${ }^{279}$ Ibid. p. 134

${ }^{280}$ GRECO, Rogério. Op. cit. p. 473

${ }^{281}$ Ibid. p. 475 e 437

${ }^{282}$ Art. 138, $\S 3^{\circ}$ do Código Penal Brasileiro: "Admite-se a prova da verdade, salvo: I - se, constituindo o fato imputado crime de ação privada, o ofendido não foi condenado por sentença irrecorrível; II - se o fato é imputado a qualquer das pessoas indicadas no $\mathrm{n}^{\circ}$ I do art. 141; III - se do crime imputado, embora de ação pública, o ofendido foi absolvido por sentença irrecorrível”.
} 
com a majesgatada de seu cargo"283. Na mesma linha, Heleno Fragoso se arvora na função em si do Presidente e sua "alta relevância política" para fundamentar a vedação da exceção da verdade nestes casos, uma vez que o cargo "exige autoridade e respeito, que seriam certamente abalados, se fosse possível procurar provar a verdade de uma imputação caluniosa"284. Deste modo, este lógica essencialmente justifica a sanção penal de qualquer pessoa que critique ou divulgue ações criminais cometidas pelo principal representate do povo. A doutrina contemporânea tampouco busca fazer uma critica do dispotivo. Damásio fundamenta o mesmo pela necessidade de impedir que terceiros interfiram no exercício da função de Presidente ${ }^{285}$, enquanto Mirabete fala da necessidade de proteger especialmente o Presidente e Chefes de Govenro "pela dignificante função que exercem, quer pelas repercussões internas e externas do fato" ${ }^{286}$. Por sua vez, Greco, ao mesmo tempo em que se propõe atualizar a fundamentação do dispotivo ao afirmar a necessidade de proteger o Presidente contra acusações daqueles que não possuem a competência constitucional para dar início à ação penal ${ }^{287}$, se utiliza da doutrina de Bittencourt, quem leciona que "a imputação da prática de fato criminoso, mesmo verdadeir, vilipendiaria a autoridade desempenha, e exporia ao ridículo do Presidente da República, alem de levá-lo a um vexame incompatível com a grandeza de seu cargo" ${ }^{288}$.

Estas justificativas da proibição da prova da verdade contra o Presidente parecem paradoxais ao se considerar a defesa do penalistas à existência da exceção da verdade para o crime de difamação quando cometido contra funcionários públicos no exercício de suas funções, previsto no art. 139, parágrafo único ${ }^{289}$, única disposição do Código Penal

\footnotetext{
${ }^{283}$ HUNGRIA, Nelson. Op. cit. p. 82

${ }^{284}$ FRAGOSO, Heleno. Lições de Direito Penal. Vol. 1. Op. cit. p. 154

${ }^{285}$ DAMÁSIO, E. De Jesus. Direito Penal - Parte Especial. p. 219

${ }^{286}$ MIRABETE, Julio \& FABBRINI, Renato. Op. cit. p. 118

${ }^{287}$ GRECO, Rogério. Op. cit. p. 435

${ }^{288}$ Idem.

${ }^{289} \mathrm{O}$ artigo 139 do Código Penal brasileiro prevê: "Difamar alguém, imputando-lhe fato ofensivo à sua reputação: Pena - detenção, de três meses a um ano, e multa. Exceção da verdade. Parágrafo
} 
que parece buscar reverter a lógica de maior proteção a agentes do Estado contra a expressão crítica. Na linha da doutrina de Blackstone, o tipo penal em si da difamação não prevê a possibilidade de prova de que o fato imputado a alguém é verdade, uma vez que tanto fatos verdadeiros como falsos podem diminuir ou afetar a reputação de alguém. A doutrina brasileira, seguindo a linha de Nelson Hungria, leciona que o tipo busca impedir que as pessoas se transformem em censores da conduta uns dos outros, efetivamente justificando a sanção criminal da crítica. Enquanto haveria um interesse público na existência da exceção da verdade para o crime de calúnia, Hungria argumenta que

"[a] liberdade da censura pública em torno às ações criminosas atende a um relevante interesse social, pois concorre para o escarmento dos que delinquem. Já o mesmo não acontece, via de regra, com os fatos que, embora reprováveis, não chegam a violar o mínimo ético protegido pela lei penal. Aqui, o preponderante interesse público é o de evitar que os cidadãos se arvorem em censores mútuos, com evidente perigo para a paz social" ${ }^{\prime 290}$.

Não obstante, neste ponto o Código Penal prevê a possibilidade do uso do instituto da exceção da verdade naqueles casos em que a difamação é cometida contra funcionários públicos por fatos relativos ao exercício de suas funções. Ao comentar o artigo, a doutrina então cita o interesse público da sociedade nas atividades de funcionários públicos, que então justificaria que haja crime quando um fato verdadeiro - mas danoso da reputação - seja inflingido contra tais funcionários ${ }^{291}$. Nelson Hungria, se utilizando do argumento quanto à necessidade do controle democrático, afirma que tal exceção "atende a um postulado democrático-liberal", uma vez que "nos países não empolgados pelo autoritarismo estatal, o exercício dos cargos públiocs, criados para servir ao interesse coletivo, não pode deixar de ficr exposto à censura pública" ${ }^{" 292}$, sendo necessária a livre crítica dos cidadãos sobre a conduta de seus governantes ${ }^{293}$.

único - A exceção da verdade somente se admite se o ofendido é funcionário público e a ofensa é relativa ao exercício de suas funções."

${ }^{290}$ HUNGRIA, Nelson. Op. cit. p. 81

${ }^{291}$ FRAGOSO, Heleno. Lições de Direito Penal. Vol. 1. Op. cit. p. 160; MIRABETE, Julio \& FABBRINI, Renato. Op. cit. p. 128.

${ }^{292}$ HUNGRIA, Nelson. Op. cit. p. 88

${ }^{293}$ Idem. 
É importante notar, portanto, que mesmo a doutrina criminal clássica reconhece a existência da necessidade de proteção da crítica da sociedade sobre a ação de funcionários e autoridades públicas. No entanto, a defesa de tal proteção aparece em um contexto que a torna frágil, paradoxal, e consequentemente esvaziada. Por um lado, a doutrina afirma a necessidade da realização de um controle democrático sob as atividades de funcionários públicos. Por outro lado, a mesma doutrina justifica uma maior punição aplicada a todos os crimes contra a honra cometidos contra funcionários públicos no exercício de suas funções pela necessidade de proteção da administração pública contra algo que possa diminuir seu prestígio ou honorabilidade, assim como proíbe a exceção da verdade em casos de calúnia cometida contra o Presidente na majestade de seu cargo.

Ademais, a própria forma como a doutrina busca proteger a crítica contra agentes públicos no exercício de suas funções é extremamente limitada. Como já apontado anteriormente, a utilização do dispositivo da "exceção da verdade" em grande parte das vezes não é adequado ou efetivo para a proteção da liberdade de expressão crítica, uma vez que este só diz respeito a juízos que podem ser provados como factuais, não sendo aplicado a juízos de valor, como aqueles no geral enquadrados sob o crime de injúria, extremamente comuns na crítica ao governo. A exceção da verdade também inverte o ônus da prova, tornando o réu - e não o autor - o responsável por provar sua própria inocência, e com o ônus de provar para a satisfação de um juízo a absoluta veracidade do fato imputado, em uma inversão do da doutrina da real malícia.

Além dos dispostivos citados, outras disposições previstas no Código Penal referentes aos crimes contra a honra protegem ainda mais autoridades públicas contra críticas ou opiniões ofensivas. Neste sentido, citamos aqui duas normativas finais que demonstram tal lógica de tutela. A primeira, se origina diretamente do aumento de pena para os crimes cometidos contra funcionários públicos no exercício de suas funções ou contra o Presidente da República: o julgamento necessariamente do crime de calúnia quando 
cometido nestas circunstâncias pela Justiça Comum, e não pelos Juizados Especiais Criminais. Tal efeito ocorre pelo aumento de pena tornar necessariamente a pena do crime de calúnia maior do que os dois anos máximos permitidos para o julgamento pelo JECRIM, e faz com que o réu não possa se utilizar de benefícios como a transação penal para evitar uma condenação criminal $^{294}$. A segunda norma protetora, também de cunho processual, é prevista nos artigos 145, parágrafo único ${ }^{295}$, os quais prevêem a ação penal pública condicionada à representação para o julgamento dos crimes contra a honra contra funcionários públicos no exercício de suas funções e contra o Presidente da República. No primeiro caso, a representação é dada pelo ofendido, enquanto no segundo pelo Ministro da Justiça. Em ambas as situações, no entanto, a ação penal é pública, e não privada, como nos demais casos relativos aos crimes contra a honra. Neste ponto, é importante ressaltar que a ação penal pública por representação funciona como a ação penal pública incondicionada, apenas com o requisito de que a representação seja realizada para que se dê início às investigações e que a denúncia seja apresentada.

\section{2.c $\mathrm{O}$ crime de desacato à autoridade}

Demonstradas as disposições de proteção especial à honra de funcionários públicos no exercício de suas funções relativas aos crimes contra a honra, passaremos agora a traçar algumas considerações quanto ao crime de desacato à autoridade, previsto no art. 331 do Código Penal ${ }^{296}$. Neste ponto, é importante relembrar que as "leis de desacato" dizem respeito àquelas leis que outorgam proteção especial da honra e da reputação de funcionários públicos contra opiniões críticas, ofensivas ou

\footnotetext{
${ }^{294}$ Neste sentido, ver artigo 61 da Lei 9.099/90.

${ }^{295}$ O art. 145 do Código Penal brasileiro prevê: "Nos crimes previstos neste Capítulo somente se procede mediante queixa, salvo quando, no caso do art. $140, \S 2^{\circ}$, da violência resulta lesão corporal. Parágrafo único. Procede-se mediante requisição do Ministro da Justiça, no caso do inciso I do caput do art. 141 deste Código, e mediante representação do ofendido, no caso do inciso II do mesmo artigo, bem como no caso do § $3^{\circ}$ do art. 140 deste Código".

${ }^{296} \mathrm{O}$ art. 331 do Código Penal Brasileiro prevê: "Desacatar funcionário público no exercício da função ou em razão dela: Pena - detenção, de seis meses a dois anos, ou multa".
} 
insultantes. Dentro desta definição, como já visto, o aumento do art. 141, I e II de pena relativo a todos os crimes contra a honra configura uma espécie de "lei de desacato", ao criar uma espécie qualificada do tipo que protege especialmente a estas figuras, como já visto anteriormente. Tal observação é relevante para a definição do crime de desacato per se, uma vez que este, como se verá, possui poucas distinções quando comparado com os crimes contra a honra cometidos contra funcionários públicos no exercício de suas funções. Assim, a doutrina irá se utilizar de argumentos muito similares para justificar tanto a existência do aumento de pena do art. 141, I e II quanto do crime de desacato à autoridade, do art. 331 .

No Brasil, como já ressaltado anteriormente, este tipo penal surge apenas com o Código de 1890, o qual previa que tal tipo configurava "Desacatar qualquer autoridade, ou funccionario publico, em exercicio de suas funcções, offendendo-o directamente por palavras ou actos, ou faltando á consideração devida e á obediencia hierarchica”. O Cógido de 1940 não apenas incluiu o crime, como tornou sua definição mais ampla, tornando possível o enquadramento de mais condutas no tipo ${ }^{297}$. Neste sentido, Fragoso admite a não-taxatividade deste tipo penal ao afirmar que "a lei não denife o que se entender por desacato, deixando, assim, à doutrina a fixação do conceito" ${ }^{298}$.

Diferentemente dos crimes contra a honra, o crime de desacato está previsto no Título IX do Código Penal, o qual diz respito aos crimes cometidos contra a administração pública ${ }^{299}$. Por este motivo, a doutrina afirma que o sujeito passivo do crime é, efetivamente, o Estado, embora também posse ser considerado como tal o funcionário público ${ }^{300}$. Sobre o tema, Damásio aponta que a tutela é dada à Administração Pública, buscando a proteção da "dignidade, prestígio e respeito devido aos seus

\footnotetext{
${ }^{297}$ FRAGOSO, Heleno. Lições de Direito Penal. Vol. 4. Op. cit. p. 1155

${ }^{298}$ Ibid. p. 1155

${ }^{299}$ MIRABETE, Julio \& FABBRINI, Renato. Op. cit. p. 374

${ }^{300}$ MIRABETE, Julio \& FABBRINI, Renato. Op. cit. p. 375, DAMÁSIO, E. De Jesus. Direito Penal-Parte Especial.p. 224
} 
agentes no exercício de suas funções" ${ }^{301}$. Neste viés, é importante ter em conta a similaridade do bem jurídico tutelado pelo aumento de pena do art. 141, I e II e pelo crime de desacato à autoridade, uma vez que nestes dois casos, o que se busca proteger é a reputação, honra, e dignidade da função ou do cargo que ocupa o sujeito. Deste modo, segundo Fragoso, o objetivo da tutela do crime de desacato,

"é o interesse em garantir o prestígio dos agentes do poder público e o respeito devido à dignidade de sua função, tendo-se em vista que a ofensa que lhes é irrogada, em sua presença, no exercício de sua atividade funcional ou em razão dela, atinge a própria administração pública". ${ }^{302}$

Portanto, para tal, o desacato tem como viés central o "desrespeito e [as] afronta feitas ao funcionário como tal", sendo proferidas contra este expressões "injuriosas, difamatórias, e caluniosas"303. Neste sentido, Mirabete define o desacato como a conduta de "ofender, vexar, humilhar, espezinhar, desprestrigiar, menosprezar, menoscabar, ou agredir o funcionário, ofendendo a dignidade ou o decoro da função" ${ }^{304}$, demonstrando a abertura do tipo penal ao afirma que "até o riso ou sorriso (...) esta injúria qualificada que é o desacato" ${ }^{\# 05}$. De mesma forma, Damásio aponta que o crime consiste em "ofender, humilhar, agredir, desprestigiar o funcionário público" ${ }^{306}$.

Com base nesta definição, a doutrina criminal lecionada que a única diferença substancial entre um crime contra a honra cometido contra um funcionário público no exercício de suas funções e o crime de desacato à autoridade consiste em seu cometimento na presença ou não do ofendido, devendo estar este no exercício do cargo ${ }^{307}$. No primeiro caso, a ofensa à honra será configurada como desacato à autoridade, enquanto na segunda

\footnotetext{
${ }^{301}$ DAMÁSIO, E. De Jesus. Direito Penal - Parte Especial. p. 223

${ }^{302}$ FRAGOSO, Heleno. Lições de Direito Penal. Vol. 4. Op. cit. p. 1155

${ }^{303}$ Ibid. p. 1157

${ }^{304}$ MIRABETE, Julio \& FABBRINI, Renato. Op. cit. p. 375

${ }^{305}$ Ibid. p. 376

${ }^{306}$ DAMÁSIO, E. De Jesus. Direito Penal - Parte Especial.p. 224

${ }^{307}$ HUNGRIA, Nelson. Op. cit. p, 94. FRAGOSO, Heleno. Lições de Direito Penal. Vol. 1. Op. cit. p. 331 e 141, e Lições de Direito Penal. Vol. 4. Op. cit. p. 1158.
} 
situação, como crime contra a honra qualificado pelo artigo 141 , I e II $^{308}$. Esta diferença meramente circunstâncial entre os dois tipos penais é de especial importância, uma vez que demonstra que a ratio legis de proteção especial de tais figuras contra a crítica ou expressões tidas como ofensivas e insultantes é, em sua essência a mesma: a proteção do prestígio e do respeito devido a uma função pública.

Neste ponto, é fundamental ressaltar que, no direito brasileiro, o crime de desacato à autoridade, apesar de possuir uma definição ampla e não taxativa, não engloba outras condutas ilícitas concretas de desrespeito a ordens legais de autoridades públicas, tutelando exclusivamente a expressão insultante, degradante, ofensiva, ou crítica dirigida a funcionários públicos no exercício de sua função ${ }^{309}$. Assim, são crimes como os de resistência ${ }^{310}$ e desobediência $^{311}$, previstos no mesmo capítulo do código, que irão tutelar condutas que não se restringem à expressão com o dolo de injuriar, difamar, ou caluniar o agente público em sua presença. $\mathrm{O}$ crime de desacato à autoridade, portanto, assim como o art. 141, I e II do Código Penal, tem como único objetivo conferir tal proteção especial a estas figuras contra a expressão que lhes possa ofender a honra ou a reputação. De maneira ainda mais grave do que no caso dos crimes contra honra, no entanto, o crime de desacato à autoridade sequer autoriza o uso da exceção da verdade em qualquer circunstância, e é objeto de ação penal pública incondicionada.

Como já ressaltado anteriormente, é notável que, apesar das implicações de todas as proteções especiais contra discurso crítico de autoridades e funcionários públicos outorgadas pela normativa da qualificadora dos crimes contra a honra e do tipo de penal de desacato, a doutrina penal em momento algum trata de um possível conflito de tais

\footnotetext{
${ }^{308}$ MIRABETE, Julio \& FABBRINI, Renato. Op. cit. p. 377, DAMÁSIO, E. De Jesus. Direito Penal - Parte Especial. p. 226

${ }^{309}$ FRAGOSO, Heleno. Lições de Direito Penal. Vol. 4. Op. cit. p. 1160.

${ }^{310} \mathrm{O}$ art. 329 do Código Penal brasileiro prevê: "Resistência - Opor-se à execução de ato legal, mediante violência ou ameaça a funcionário competente para executá-lo ou a quem lhe esteja prestando auxílio."

${ }^{311}$ O artigo 330 do Código Penal brasileiro prevê: "Desobediência - Desobedecer a ordem legal de funcionário público".
} 
normas com o direito à liberdade de expressão. Pelo contrario, menções a este direito são praticamente omissas, apenas aparecendo no contexto da liberdade de imprensa, com a constatação de que crimes cometidos pela imprensa podem conter um agravante de pena pelo poder da divulgação de uma ofensa. De todos os doutrinadores analizados, apenas o clássico Nelson Hungria menciona a existência de uma crítica a tais dispositivos, afimando que há quem entenda que atentados à honra deveriam exclusivamente tem como consequência sanções civis. $\mathrm{O}$ autor, no entanto, rejeita tal questionamento com a simples constação de que

"Nenhuma contemplação merecem aqueles que, por ódio, despeito, rivalidade ou ápero prazer do mal, se fazem salteadores da honra alheia. Sob certos aspectos, são eles ainda mais perversos que os próprios rapinantes, pois, segundo os versos de Shakespeare, "he that flinches me my good name robs me of that which not enriches him, and makes me poor indeed". 312

Neste sentido, é notável a falta de qualquer debate profundo dentro da doutrina criminal de questionamento de tais dispositivos, especialmente diante de seu efeito sob o direito à liberdade de expressão. Enquanto autores como XXX citam a existência a Convenção Americana sobre Direitos Humanos para tratar a necessidade de proteção à honra - direito fundamntal previsto neste tratado - não há uma análise subsequente de quais são os parâmetros existentes dentro da $\mathrm{CADH}$ para a restrição do direito à liberdade de expressão. Pelo contrário, os doutrinadores criminais seguem justificando a existência de "leis de desacato" dentro do sistema penal brasileiro, com base na necessidade de proteção da função pública diante daquela expressão crítica que é tida como "desconstrutiva", "ofensiva”, ou "insultante", sem maiores definições sobre no que estas consistem.

A falta da aplicação de parâmetros para solucionar conflitos entre o direito à liberdade de expressão e o direito à honra, especialmente nos casos relacionados à crítica ao governo e às "leis de desacato", não se restringe à doutrina criminal. De fato, a ausência de questionamentos realizados a respeito destes dispositivos ou até mesmo de uma analise mais profunda sobre sua fundamentação no âmbito do Direito Penal parece ser espelhada 
pela jurisprudência dos tribunais brasileiros, e inclusive em decisões do Supremo Tribunal Federal.

Neste sentido, no âmbito da paradigmática decisão da ADPF No. 130, que declarou a Lei de Imprensa de 1967 como não recepcionada pela constituição federal, por seu viés autoritário, o STF segue a lógica da doutrina de William Blackstone no que se trata da definição do que é a liberdade de expressão. Assim, para a mais alta corte brasileira, este direito parece consistir meramente na liberdade contra a censura prévia, devendo o legislador fixar responsabilidades ulterior para a restrição da expressão quanto esta atenta contra direitos da personalidade, como a honra e a reputação. Assim, ao mesmo tempo em que diversos Ministros em seus votos reafirmam a importância do direito à liberdade de expressão para a democracia e o controle das atividades públicas pelo povo soberano citando precedentes da Corte Interamericana de Direitos Humanos e da Suprema Corte americana para tal - estes concluem de maneira genérica que tal direito não é absoluto, e que seu abuso deve gerar consequências civis e criminais para aqueles que insultem ou ofendam outros, sendo os ofendidos funcionários públicos ou não, sem maiores reflexões sobre o tema, ou sem adentrar os parâmetros desenvolvidos pela jurisprudência internacional e comparada citadas pelo própio Tribunal para como realizar tal restrição da liberdade de expressão $0^{313}$.

Neste viés, um recente estudo da ONG Artigo XIX de decisões do STF entre os anos de 2010 e 2012 envolvendo a aplicação dos crimes contra a honra é demonstrativo da ausência de adoção dos parâmetros utilizados por tribunais internacionais e nacionais no que se trata da restrição da expressão crítica ou ofensiva pelo uso do direito penal. A título de exemplo, em suas conclusões, ONG encontrou que: em apenas $8 \%$ dos acórdãos o Supremo procurou realizar uma análise a respeito da necessidade da condenação criminal para a proteção da reputação ou honra de outrem; em

\footnotetext{
${ }^{313}$ Neste sentido, ver: STF. ADPF 130. Relator Ministro Carlos Ayres Britto. Decisão de 30 de abril de 2009, p. 30-36 e 46 a 56. Ver ainda votos dos Ministros Joaquim Barbosa, p. 144, Celso Mello, p. 157, 158, 163, e Gilmar Mendes, pp. 210-211.
} 
$75 \%$ dos casos não houve uma análise sobre se o réu possuía o dolo de ofender; nenhum dos acórdãos analisou se as declarações eram baseadas em fatos fatos, e apenas 33\% levou em consideração se estas causaram dano à reputação do ofendido ${ }^{314}$.

Enquanto não se pode afirmar que todos os acórdãos analisados no estudo diziam respeito a casos envolvendo expressões críticas relacionadas assuntos públicos, um segundo estudo realizado pela ONG entre os anos de 2005 e 2007 é demonstrativo do amplo uso de procesos com base nos crimes contra a honra por pessoas públicas contra expressões tidas como ofensivas ou insultantes. Neste sentido, ao analisar as vinte e sete decisões do Superior Tribunal de Justiça envolvendo a utilização dos crimes contra a honra neste período, se constatou que dezesseis delas diziam respeito a casos em que os autores eram pessoas que ocupavam cargos ou funções públicas. ${ }^{315}$

Conforme demonstrado, a persistência no marco jurídico brasileiro penal de figuras equivalentes a "leis de desacato", construídas para outorgar uma proteção especial a funcionários públicos no exercício de suas funções e autoridades públicas como o Presidente da República, cria e sustenta uma lógica que atenta diretamente contra o direito à liberdade de expressão como este é entendido em uma sociedade democrática, efetivamente sancionando de maneira mais grave a expressão crítica do Estado e seus representantes. De forma ainda mais preocupante, a doutrina criminal clássica e contemporânea não questiona diretamente a constitucionalidade de tais normas, e, pelo contrário, as segue justificando pela mesma lógica de necessidade da preservação do prestígio da função e ordem públicas utilizada quando da aprovação do Código de 1940, sem uma atualização do significado de tais dispositivos na nova ordem constitucional democrática.

\footnotetext{
314 Artigo XIX. Restrições Ilegítimas à Liberdade de Expressão. Documento apresentado ante a Comissão Interamericana de Direitos Humanos em 10 de março de 2008. Disponível em: $<$ http://artigo19.org/?p=127>. Acesso em 8 de novembro de 2012.

315 Artigo XIX. Difamação: Análise da Jurisprudência Nacional em Contraste com os Padrões Internacionais de Difamação. 2012. Disponível em: < http://artigo19.org/wpcontent/uploads/2012/10/AJN.pdf>. Acesso em 8 de novembro de 2012.
} 
No âmbito dos tribunais, o Supremo Tribunal Federal, enquanto reconhece a importância de tal direito para a democracia, parece seguir aplicando a lógica inglesa de Blackstone do século XVIII de maneira genérica, tratando a liberdade de expressão como a liberdade contra a censura prévia, mas passível de responsabilizações ulterior, sem, no entanto, desenvolver e aplicar parâmetros para determinar como tal responsabilização deverá ocorrer. Talvez um reflexo da falta de uma discussão jurídica detalhada sobre o tema, o anteprojeto do Código Penal apresentado em junho de 2012 tampouco apresenta mudanças substanciais sobre a proteção especial a funcionários públicos. Conforme se passará a demonstrar, enquanto alguns avanços sobre a matéria podem ser identificados, estes são pontuais, e, especialmente, não refletem uma mudança no paradigma que vem orientando a doutrina dos "crimes contra a honra" no que diz respeito à crítica relacionada a assuntos públicos.

\section{2.d $O$ anteprojeto do novo código penal}

Em junho de 2011, o Senado Federal, por meio da Resolução No. 756 solicitou a criação de uma Comissão de Juristas para a redação de um anteprojeto para um novo Código Penal, com o objeto de atualizar a legislação diante da nova ordem constitucional democrática, considerando a falta de sintonia do Código de 1940 com os desafios atuais em termos de segurança pública ${ }^{316}$. O anteprojeto foi apresentado em sua versão final um ano após a Resolução.

O projeto prevê os "Crimes contra a honra" no Capítulo IV do Código, sem apresentar mudanças substanciais na configuração dos tipos. Não obstante, as pequenas alterações realizadas em determinadas normas apontam para a outorga não de uma menor, mas em uma maior tutela outorgada pelo direito penal para a proteção da honra contra tais crimes em um caminho contrário às recentes mudanças nesta área realizadas em diversos países do hemisfério, como já visto. Assim, e a título de exemplo,

\footnotetext{
${ }^{316}$ Senado Federal. Resolução No. 756 de 2011.
} 
é notável que a pena cominada a todos os crimes contra a honra no anteprojeto é maior, e por vezes, o dobro, daquelas previstas no atual Código $^{317}$. O crime de calúnia é definitivamente excluído do rol de crimes de menor potencial ofensivo ao prever uma pena de prisão de até três anos, não podendo mais ser julgando no âmbito do JECRIM independente da aplicação de causa de aumento de pena. O crime de difamação, por sua vez, ao passar a prever uma pena de até dois anos, também deixa de ser crime de menor potencial ofensivo caso sob ele incida qualquer qualificadora.

Uma das poucas defesas previstas no Código atual ao réu nestes processos - a exceção da verdade - passa a ser aplicada apenas de modo excepcional também no crime de calúnia, e não mais somente com relação à difamação. Assim, o anteprojeto apenas autoriza a exceção da verdade naqueles casos em que a pessoa a quem o fato criminoso é imputado já tenha sido condenada pela prática de tal crime ${ }^{318}$. Efetivamente, a cláusula criminaliza a imputação de qualquer fato criminoso a alguém antes do trânsito em julgado da condenação, tirando o réu a possibilidade de prova de que o fato imputado é, de fato, verdade. Como já ressaltado anteriormente, a própria exceção da verdade não é tida como suficiente no direito internacional e comparado para a defesa do réu nestes processos. Não obstante, o anteprojeto vai ainda além, passando a proibir que o réu prove sua inocência por meio da prova da verdade dos fatos, em ainda maior restrição ao princípio da presunção de inocência.

É importante ressaltar que o texto do anteprojeto, em uma das poucas mudanças mais protetivas do discurso, prevê expressamente que a opinião desfavorável da crítica jornalística não configurará difamação ou

\footnotetext{
${ }^{317}$ Assim, a título de exemplo, o crime de calúnia teria sua pena maxima aumentada de dois para três anos (art. 136); o crime de difamação teria sua pena maxima aumentada de um para dois anos (art. 137); e o crime de injúria teria a pena máxima aumentada de seis meses para um ano (art. 138).

${ }^{318}$ Art. 136 do anteprojeto do Código Penal: "§2 caso o ofendido tenha sido condenado pela prática do crime que lhe tenha sido imputado."
} 
injúria, "salvo quando inequívoca a intenção de injuriar ou difamar"319 . Não obstante, tal cláusula, assim como a exceção da verdade, não parece ser suficiente para a proteção da expressão crítica. Primeiramente, a restrição à "crítica jornalística" poderia ser interpretada como restrita àqueles que possuem a profissão de jornalista, excluindo assim aquela crítica especialmente de caráter político - realizada por qualquer pessoa da sociedade. Em segundo lugar, a ressalva de que tal exclusão só ocorrerá quando não for "inequívoca a intenção de injuriar ou difamar" esvazia a cláusula, a tornando demasiado aberta, e consequentemente a total critério dos tribunais. Note-se ainda que a propagação de uma opinião com frequente poderá ocorrer com a intenção de ofender, especialmente se esta for crítica. Do mesmo modo, a propagação de um fato sobre alguém por um jornalista também possivelmente terá o dolo de diminuir a reputação de tal pessoa ante a opinião pública. A existência de tais dolos não significa, no entanto, que se deve sancionar criminalmente juízos de opinião ou juízos de fato cometidos sem real malícia. Para além disto, no entanto, o exigido pelo direito penal já seria de que uma pessoa não fosse condenada sem a inequívoca prova do dolo de cometer um crime (salvo os crimes que possuem modalidade culposa), o que tornaria a ressalva desnecessária. Efetimente, a cláusula parece prever que, quando ambíguo o dolo de injuriar ou difamar da crítica jornalística, o réu não deveria ser condenado, disposição que deveria, no entanto, ser claramente aplicável para o cometimento de qualquer dos crimes contra a honra por qualquer pessoa.

No que tange a proteção especial outorgada a agentes públicos no exercício de suas funções, a causa de aumento de pena prevista no código atual para todos os crimes contra a honra cometidos nestas circunstâncias não foi apenas mantida, mas agravada, cristalizando a manutenção das "leis de desacato" no sistema penal brasileiro. Assim, o artigo 140 do anteprojeto prevê o aumento da pena em até o dobro em ofensas cometidas "contra

\footnotetext{
${ }^{319}$ Art. 141 do anteprojeto do Código Penal: "Não constituem difamação ou injúria: II - a opinião desfavorável da crítica literária, artística científica, salvo quando inequívoca a intenção de injuriar difamar".
} 
servidor público, em razão de suas funções", enquanto o Código atual prevê o aumento de até um terço. Efetivamente, tal disposição torna possível, por exemplo, que uma pessoa seja condenada pelo crime de difamação a até quatro anos de prisão por propagar fatos verdadeiros sobre o exercício de uma função pública que sejam considerados danosos à reputação do servidor público. Enquanto o projeto manteve a possibilidade de exceção da verdade para tais situações ${ }^{320}$ (como já prevê o Código atual), como já ressaltamos, esta proteção não é suficiente para evitar a autocensura daqueles que acreditam não possuírem inequivocadamente os meios de provar ante um tribunal a verdade de suas imputações, além de inverter o ônus da prova em um processo penal, e de ir de encontro com o parâmetro da real malícia, considerado por muitos tribunais o mínimo necessário para a garantia do direito à liberdade de expressão no contexto da crítica ao Estado em uma sociedade democrática. $\mathrm{O}$ anteprojeto ainda prevê a manutenção da ação penal pública por representação nestes casos, apesar de também adicionar a possibilidade da apresentação de queixa, criando duas vias possíveis para servidores públicos na persecução penal de tais crimes $^{321}$.

O agravamento da cláusula de aumento de pena do art. 140 é justificado no próprio texto do anteprojeto como a necessidade de oferecer "tutela à atuação funcional dos servidores públicos, anteriormente objeto do crime de desacato" ${ }^{322}$. Efetivamente, o projeto prevê a descriminalização do tipo penal hoje conhecido como "desacato à autoridade", em uma tentativa de, nas palavras do próprio texto do anteprojeto, afastar "a crítica de que existiria um viés autoritário nesta proteção especial ao servidor público" ${ }^{\text {"23. }}$. No entanto, é essencial ressaltar que o projeto não busca eliminar a ratio

\footnotetext{
${ }^{320}$ Art. 138 do anteprojeto do Código Penal: "§2o A exceção da verdade somente se admite se o ofendido é: I - servidor público e a ofensa é relativa ao exercício de suas funções".

${ }^{321}$ Art. $144, \S 1^{\circ}$ do anteprojeto do Código Penal: "Nas ofensas irrogadas contra o servidor público, no exercício de suas funções, é concorrente a legitimidade do ofendido, mediante queixa, e do Ministério Público, condicionada à representação do ofendido, para a propositura de ação penal."

${ }^{322}$ Relatório final da Comissão de Juristas para a Elaboração do Anteprojeto do Novo Código Penal. 18 de junho de 2012, p. 367.

${ }^{323}$ Idem.
} 
legis do desacato, isto é, tutela especial da honra e reputação de servidores públicos no exercício de sua função, mas apenas a transporta para a causa de aumento de pena prevista no art. 140, explicitamente prevendo que "o desacato foi transformado em injúria qualificada" ocorrendo a eliminação do crime de desacato à autoridade "sem deixar, todavia, de manter como crime a ofensa a eles realizada em razão da função" ${ }^{\text {"324 }}$. É dizer: em uma tentativa de rebater críticas a respeito do caráter autoritário do crime designado como "desacato", o anteprojeto explicitamente, e sem atentar para a ratio que substancia tal crítica, segue tutelando de maneira especial a honra e a reputação de servidores públicos no exercício de suas funções, em uma disposição equivalente às "leis de desacato". Fica claro, portanto, que a lógica que rege a aparente justificativa de tal proteção especial não foi em nada alterada.

Deste modo, enquanto se pode argumentar que a descriminalização do tipo penal "desacato à autoridade" é um avanço, uma vez que não mais existem duas disposições normativas no Código Penal brasileiro que outorgam esta proteção especial, é preciso grande cautela. Em primeiro lugar, e como já mencionado no item anterior, o crime de desacato à autoridade como previsto no Código atual não realizada nada mais do que tutelar as injúrias, calúnias, e difamações cometidas na presença do funcionário público, não se diferindo em termos do bem jurídico tutelado da causa de aumento de pena do art. 141, I e II. Assim, o anteprojeto apenas agrupa em um tipo só a proteção especial da honra e reputação de agentes públicos, sem eliminar a tutela de tal bem de maneira mais agravada, mantendo assim a disposição de desacato sob um outro nome. Ademais, enquanto no sistema atual o desacato possui uma pena de até dois anos para o crime de desacato à autoridade, $\mathrm{o}$ anteprojeto torna a ofensa ao servidor público - em sua presença ou não - punível por até seis anos, no caso da calúnia, quatro anos, no caso da difamação, e dois anos, no caso da injúria. 
A resposta dada pelo anteprojeto à crítica de que o crime de desacato não se sustenta em uma sociedade democrática é, portanto, esvaziada, e meramente formal, não configurando uma mudança na antiga lógica autoritária que determina a necessária de proteção especial de agentes do governo contra expressões críticas, ofensivas, ou insultantes a estes quando no exercício de atividades pública. 


\section{Conclusão}

Conforme se procurou demonstrar, o direito à expressão crítica do Estado e seus agentes é uma condição fundamental para o funcionamento de uma democracia representativa, permitindo o controle social das atividades públicas, e a discussão aberta e ampla sobre assuntos públicos concernentes à sociedade. Tal relação entre a liberdade de expressão crítica e a democracia vem sendo traçada desde o século XVII por filósofos, políticos, e, finalmente, por órgãos jurídicos nacionais e internacionais, com a conclusão de que é necessária uma maior proteção a este tipo de discurso.

Não obstante, é ainda persistente no ordenamento jurídico brasileiro disposições que não apenas sancionam criminalmente esta expressão, mas que protegem de maneira especial a honra e a reputação de autoridades e funcionários públicos no exercício de suas funções, em uma total inversão da lógica democrática. De modo ainda mais preocupante, as mudanças atualmente propostas de reforma ao Código Penal - ao mesmo tempo que buscam formalmente descriminalizar a figura do desacato - seguem perpetuando a ideia de que a honra daqueles que ocupam uma função estatal deve ser tutelada pelo direito criminal de maneira mais severa do que a de cidadãos privados, com graves consequências para o direito à liberdade de expressão.

Sem que haja uma real discussão no âmbito da doutrina e jurisprudência brasileiras a respeito do fundamento das "leis de desacato" e seu lugar na nove ordem democrática estabelecida pela Constituição de 1988, tudo indica que tais dispositivos - e a lógica autoritária que os sustentam - seguirão mantidos em nosso marco normativo, efetivamente criminalizando de maneira especial a crítica ao Estado e seus servidores, representantes de um povo, ao menos formalmente, soberano. 


\section{Bibliografia}

ABRAMOVICH, Victor. De las violaciones masivas a los patrones estructurales: nuevos enfoques y clásicas tensiones en el Sistema Interamericano de Derechos Humanos. Sur: revista internacional de derechos humanos da Red Universitaria de Derechos Humanos. V. 6, No. 11, dezembro, 2009

Areopagitica. In: Encyclopedia Britânica On-line. Disponível em: $<$ http://www.britannica.com/EBchecked/topic/33505/Areopagitica $>$.

Acesso em 8 de novembro de 2012

Artigo XIX. Difamação: Análise da Jurisprudência Nacional em Contraste com os Padrões Internacionais de Difamação. 2012. Disponível em: < http://artigo19.org/wp-content/uploads/2012/10/AJN.pdf $>$. Acesso em 8 de novembro de 2012

Artigo XIX. Restrições Ilegítimas à Liberdade de Expressão. Documento apresentado ante a Comissão Interamericana de Direitos Humanos em 10 de março de 2008. Disponível em: <http://artigo19.org/?p=127>. Acesso em 8 de novembro de 2012

BLACKSTONE, William. Commentaries on the Laws of England, 1769

CIDH. Declaração de Principios sobre Liberdade de Expressão. Disponível em: $<$ http://www.oas.org/es/cidh/expresion/showarticle.asp?artID=132\&IID=2> . Acesso em 8 de novembro de 2012

CIDH. Informa Anual da Relatoria para Liberdade de Expressão de 2002. Disponível

em:

$<$ http://www.oas.org/es/cidh/expresion/showarticle.asp?artID=138\&lID=2> . Acesso em 8 de novembro de 2012

CIDH. Informe Anual da Relatoria para a Liberdade de Expressão de 2004. Disponível em: $<$ http://www.oas.org/es/cidh/expresion/showarticle.asp?artID=459\&lID=2> . Acesso em 8 de novembro de 2012

CIDH. Informe Anual da Relatoria para a Liberdade de Expressão de 2005. Disponível

em: $<$ http://www.oas.org/es/cidh/expresion/showarticle.asp?artID=662\&lID=2> . Acesso em 8 de novembro de 2012

CIDH. Informe Anual da Relatoria para a Liberdade de Expressão de 2007. Disponível em: $<$ http://www.oas.org/es/cidh/expresion/docs/informes/anuales/2012\%2003 \%2021\%20Informe\%20Anual\%20RELE\%202011\%20impresion.pdf $>$. Acesso em 8 de novembro de 2012

$\mathrm{CIDH}$. Informe Anual de 1994. Capítulo V: Informe sobre la compatibilidade entre las leyes de desacato y la Convención Americana sobre Derechos

Humanos.

Disponível

em: 
$<$ http://www.cidh.org/annualrep/94span/cap.V.htm>. Acesso em 8 de novembro de 2012

CIDH. Informe Anual do Relator para a Liberdade de Expressão de 2000. Disponível em: http://www.oas.org/es/cidh/expresion/showarticle.asp?artID=136\&lID=2>. Acesso em 8 de novembro de 2012

CIDH. Informe de país sobre o Paraguay de 1998, par. 15. Disponível em: $<$ http://www.cidh.org/countryrep/paraguay01sp/cap.6.htm $>$. Acesso em 8 de novembro de 2012

CIDH. Informe Especial do Relator de Liberdade de Expressão de 1998. Disponível em: $<$ http://www.oas.org/es/cidh/expresion/showarticle.asp?artID=134\&IID=2> . Acesso em 8 de novembro de 2012

CIDH. Informe No. 22/94. Caso 11.012 (Argentina). Solução amistosa, 20 de setembro de 1994

CIDH. Mandato de la Relatoría Especial para la Libertad de Expresión. Disponível

em: $<$ http://www.oas.org/es/cidh/expresion/mandato/default.asp $>$. Acesso em 8 de novembro de 2012

CIDH. Relatoria para a Liberdade de Expressão. Comunicado de Imprensa R128/12. Disponível

em: $<$ http://www.oas.org/es/cidh/expresion/showarticle.asp?artID=912\&lID=2> . Acesso em 8 de novembro de 2012

CIDH. Relatoria para la libertad de expresión. Disponível em: $<$ http://www.oas.org/es/cidh/expresion/index.asp $>$. Acesso em 8 de novembro de 2012

Corte de Constitucionalidade da Guatemala. Expediente No. 1122-2005. 1 de fevereiro de 2005

Corte IDH. Caso Herrera Ullhoa v. Costa Rica. Sentença de 2 de julho de 2004. Série C No. 107; Caso Ricardo Canese v. Paraguay. Sentença 31 de agosto de 2004. Série C No. 111; Caso Kimel v. Argentina. Sentença de 2 de maio de 2008. Série C No. 177; Caso Tristán Donoso v. Panamá. Sentença de 27 de janeiro de 2009. Série C No. 193; Caso Usón Ramírez v. Venezuela. Sentença de 20 de novembro de 2009. Série C No. 207

Corte IDH. Opinião Consultiva No. 5/85 de 13 de novembro de 1985. Série A No. 5., pars. 50 e 51

Costa Rica. Congresso Nacional. Lei No. 8224. Derogación del tipo penal de Desacato

Court of Star Chamber. In: ___ Encyclopedia Britânica Online. Disponível em: $<$ http://www.britannica.com/EBchecked/topic/563475/Court-of-StarChamber $>$. Acesso em 8 de novembro de 2012 CURTIS, Michael Kent. Free Speech, "The People's Darling Privilege": Struggles for Freedom of Expression in American History. Edição do Kindle (Amazon). Durham e Londres: Duke Univeristy Press, 2000 
DAMÁSIO, E. De Jesus. Direito Penal - Parte Especial. 4o. Volume. 13a Edição. São Paulo: Saraiva, 2003

DE TOCQUEVILLE, Alexis. Democracy in America. Volume um. Edição do Kindle (Amazon). Domínio público, 1835, p. 145

FELDMAN, Stephen. Free expression and Democracy in America: A History. Edição do Kindle (Amazon). Chicago e Londres: Unuversity of Chicago Press, 2008

FRAGOSO, Heleno. Lições de Direito Penal. Vol. 1. $2^{\text {a }}$ Edição. São Paulo: José Bushatsky, São Paulo, 1962

FRAGOSO, Heleno. Lições de Direito Penal. Vol. 4. $2^{\text {a }}$ Edição. São Paulo: José Bushatsky, São Paulo, 1965

GRECO, Rogério. Curso de Direito Penal. Vol. II. Niterói: Imprenta, 2007 HUNGRIA, Nelson. Comentários ao Código Penal. Vol. VI. $4^{\text {a }}$ Edição. Rio de Janeiro: Forense, 1958

IPI/IFEX. Colorado Repeals Criminal Libel Law. 20 de abril de 2012. Disponível em: $<$ http://www.ifex.org/united_states/2012/04/20/colorado_repeal/>. Acesso em 8 de novembro de 2012

June 1643: An Ordinance for the Regulating of Printing. Atos e ordenâncias do Interregnum, 1642-1660 (1911). Disponível em: $<$ http://www.british-history.ac.uk/report.aspx?compid=55829>. Acesso em 8 de novembro de 2012

LEWIS, Anthony. Freedom for the Thought That We Hate: A Biography of the First Amendment. Edição do Kindle (Amazon). Nova Iorque: Basic Books, 2007

MADISON, James. Virginia Resolution. 1798. Disponível em: $<$ http://www.let.rug.nl/usa/documents/1786-1800/virginia-resolution1798.php>. Acesso em 8 de nobembro de 2012

MILL, John Stuart. On Liberty and Other Essays. Edição de Kindle (Amazon), 1869

MILTON, John. Areopagitica: A speech for the Liberty of Unlicensed Printing to the Parliament of England. Edição de Kindle (Amazon). Domínio público

MIRABETE, Julio \& FABBRINI, Renato. Manual de Direito Penal. Parte Especial, Vol. II. Edição 28a. São Paulo: Atlas, 2011

OEA/Ser.L/V/II CIDH/RELE/INF. 2/09. 30 de dezembro de 2009

Organização dos Estados Americanos. Carta Democrática Interamericana. Aprovada na primeira sessão plenária, realizada em 11 de setembro de 2011 , art. 4

Organization for Security and Co-operation in Europe. Liber and Insult Laws: A Matrix on Where We Stand and What We Would Like to Achieve. Vienna, 2005. Disponível em: $<$ http://www.osce.org/fom/41958>. Acesso em 8 de novembro de 2012

Relatoria para a Liberdade de Expressão da Comissão Interamericana de Direitos Humanos. Una agenda hemisferica para la defensa de la libertad 
de expresión. OEA/Ser.L/V/II CIDH/RELE/INF. 4/09, 25 de fevereiro de 2009

Relatório final da Comissão de Juristas para a Elaboração do Anteprojeto do Novo Código Penal. 18 de junho de 2012

Sedition Act, aprovado em 14 de julho de 1798. Disponível em: < http://www.constitution.org/rf/sedition 1798.htm $>$. Acesso 8 de novembro 2012

STF. ADPF 130. Relator Ministro Carlos Ayres Britto. Decisão de 30 de abril de 2009

Supreme Court of the United States. Abrams et al v. United States/250 U.S. 616, Rel. Justice Clarke, District of Columbia, 10 de novembro de 1919 Supreme Court of the United States. Garrison v. Lousiana/379 U.S. 64 Rel. Justice Brennan, District of Columbia, 23 de novembro de 1964 